\title{
Working
}

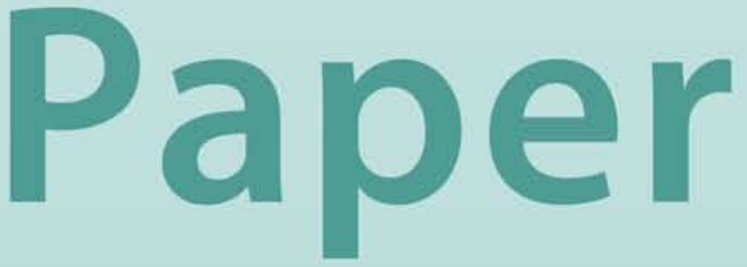




\section{Efficiency and Performance of Bulgarian Private Pensions}

Gregorio Impavido 


\title{
IMF Working Paper
}

Monetary and Capital Markets Department

\section{Efficiency and Performance of Bulgarian Private Pensions}

\author{
Prepared by Gregorio Impavido ${ }^{\dagger}$
}

Authorized for distribution by Ceyla Pazarbasioglu

December 2008

\begin{abstract}
This Working Paper should not be reported as representing the views of the IMF. The views expressed in this Working Paper are those of the author(s) and do not necessarily represent those of the IMF or IMF policy. Working Papers describe research in progress by the author(s) and are published to elicit comments and to further debate.
\end{abstract}

This paper analyzes the performance of the Bulgarian private defined contribution pensions in the second and third pillars of the pension system.

JEL Classification Numbers: G23.

Keywords: Private pensions, second pillar.

Author’s E-Mail Address: gimpavido@imf.org

${ }^{\dagger}$ Gregorio Impavido is Senior Financial Sector Expert at the IMF. The author is grateful for the comments received by Ceyla Pazarbasioglu, Tonny Lybek and Michaela Erbanova (all IMF); Fernando Montes Negret and Dimitri Vittas (all World Bank); and Bisser Petkov (FSC). This paper reflects the view of its author, not necessarily those of the affiliation institution. The usual caveat applies. 


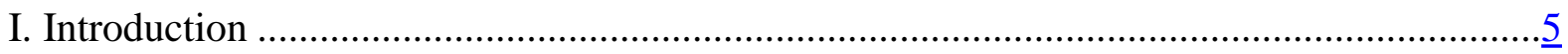

II. Brief Description of the Bulgarian Pension System........................................................

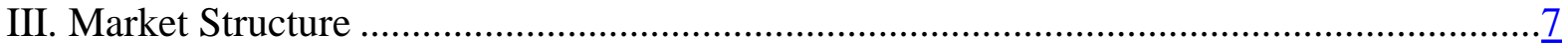

IV. Asset Allocation and Investment Performance......................................................13

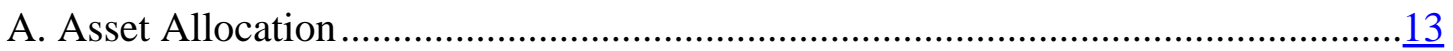

B. Investment Performance..................................................................... $\frac{17}{17}$

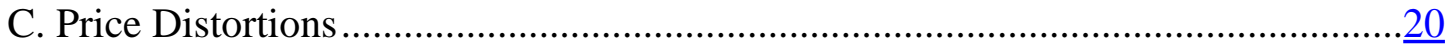

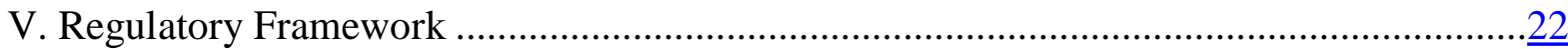

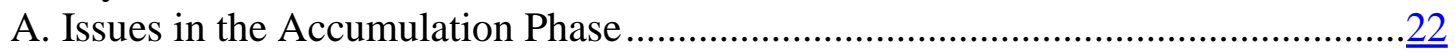

B. Issues in the Payout Phase ...........................................................................

VI. Policy Conclusions ........................................................................................... 4

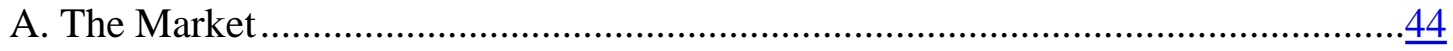

B. Regulation and Supervision ...................................................................

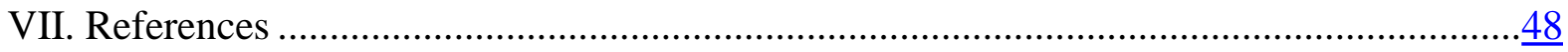

Tables

1. Key Features of the Bulgarian Pension System ...............................................................

2. Number of Legal Entities..........................................................................................

3. Direct Shareholding Structure of PICs ..................................................................... $\underline{8}$

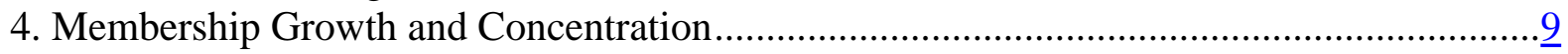

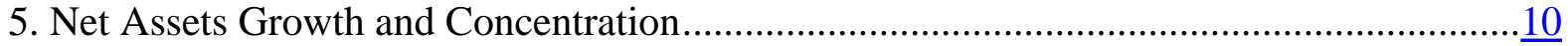

6. Annual Contributions Growth and Concentration ....................................................... 10

7. Assets of Autonomous Pension Funds in Select OECD and non-OECD Countries ............11

8. Concentration Indicators-Select Countries............................................................. 12

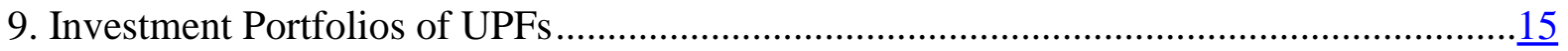

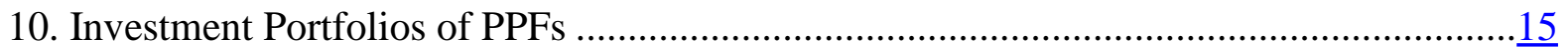

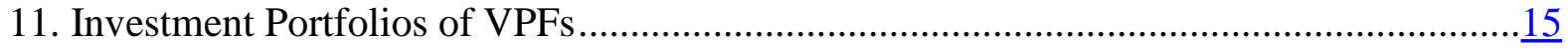

12. Average Maturity of PICs’ Bond Portfolio (March, 2007)............................................17

13. Gross Nominal and Real Investment Performance, 2002-2007 .....................................18

14. International Comparison of Real Rates of Returns .................................................. $\frac{18}{19}$

15. Net Nominal Investment Performance, 2003-2007.................................................... 19

16. Concentration and Market Power-Select Countries ...................................................21

17. Minimum Return Guarantee in Select Countries.........................................................29

18. Standard Deviation in Portfolio Weights and Returns of PICs.......................................31

19. Price Regulation in Select Countries. ........................................................................

20. Forty-year AUM Equivalent First Floor Fees (Select Countries, Percent).......................

21. Number of Transfers across Latin American Pension Funds, 2000 - mid-2007................ㅡㅛ 
Figures

1. Asset Allocation in 2006 in Select OECD Countries ......................................................14

2. Asset Allocation of Bulgarian Pension Funds, 2004-07 .............................................16

3. Forty-year Charge Ratios in Select Countries ............................................................33

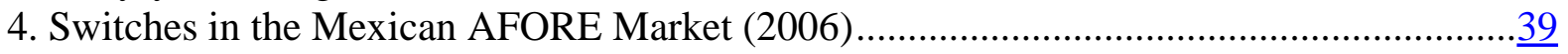

Appendixes

I. Overview of Second and Third Pillars Institutional Arrangements .................................49

II. Detailed Data by Legal Entity ........................................................................

III. Investment Rules for Pension Funds....................................................................62

IV. Relationship Between Concentration, Market Power and Demand Elasticity ..................66

Appendix Tables

22. Membership by Legal Entity …........................................................................

23. Net Assets by Legal Entity .............................................................................52

24. Annual Contributions by Legal Entity ……..............................................................

25. Annual Gross Investment Performance by Legal Entity ….......................................54

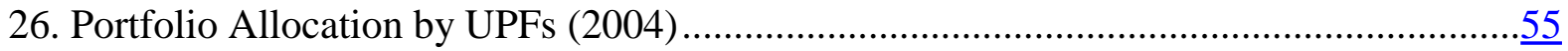

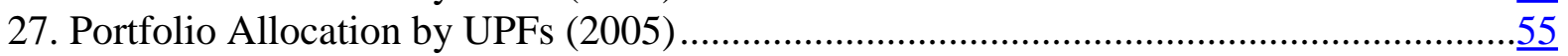

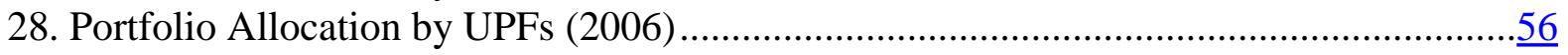

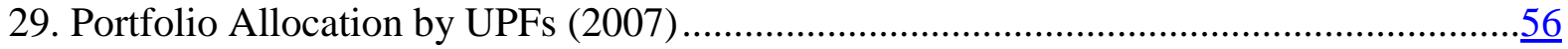

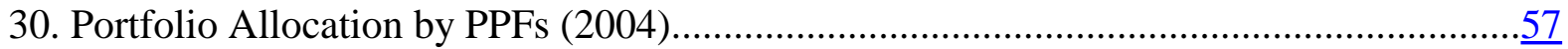

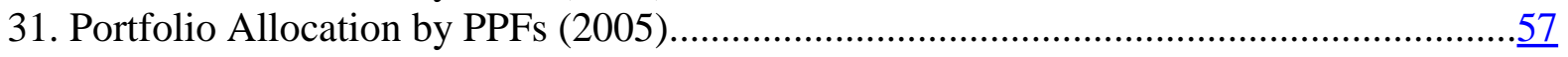

32. Portfolio Allocation by PPFs (2006).....................................................................58

33. Portfolio Allocation by PPFs (2007) .....................................................................58

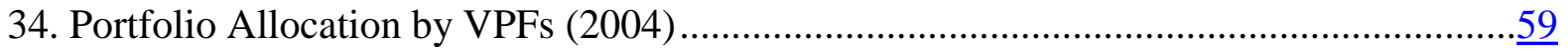

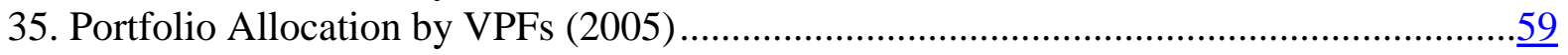

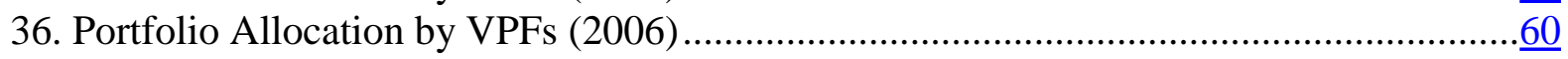

37. Portfolio Allocation by VPFs (2007) ...................................................................60

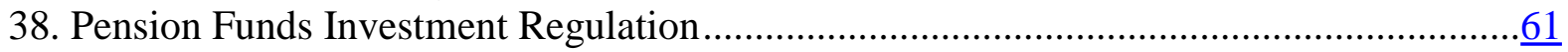

39. Lerner Indices with No Investment Income..........................................................68

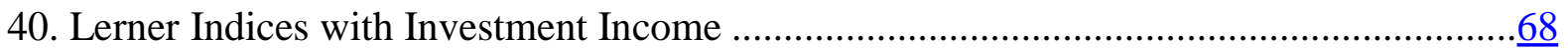


Glossary

$\begin{array}{ll}\text { AA } & \text { Annualized Average } \\ \text { AUM } & \text { Assets Under Management } \\ \text { BSE } & \text { Bulgaria Stock Exchange } \\ \text { CIS } & \text { Collective Investment Scheme } \\ \text { DB } & \text { Defined Benefit } \\ \text { DC } & \text { Defined Contribution } \\ \text { ECB } & \text { European Central Bank } \\ \text { EEA } & \text { European Economic Association } \\ \text { EIB } & \text { European Investment Bank } \\ \text { EU } & \text { European Union } \\ \text { FSC } & \text { Financial Supervision Commission } \\ \text { FSCA } & \text { Financial Supervision Commission Act } \\ \text { HHI } & \text { Herfindahl-Hirschmann Index } \\ \text { LI } & \text { Lerner Index } \\ \text { NRA } & \text { National Revenue Authority } \\ \text { NSSI } & \text { National Social Insurance Institute } \\ \text { OPF } & \text { Occupational Pension Fund } \\ \text { PAYG } & \text { Pay-as-you-go } \\ \text { PIC } & \text { Pension insurance Company } \\ \text { PPF } & \text { Professional Pension Fund } \\ \text { SD } & \text { Standard Deviation } \\ \text { SIC } & \text { Social Insurance Code } \\ \text { UPF } & \text { Universal Pension Fund } \\ \text { VPF } & \text { Voluntary Pension Fund }\end{array}$




\section{INTRODUCTION}

1. This paper assesses the performance and efficiency of the second and third pillars of the Bulgarian pension system. The Bulgarian mandatory and voluntary defined contribution pensions follow a design typical of other countries in Eastern Europe, Central Asia region and Latin America. The Bulgarian authorities have attempted to implement policies in the accumulation phase aimed at increasing competition and transparency while containing administrative fees charged to contributors. The effectiveness of such policies is comparable to what observed in other jurisdictions with similar industrial organization of the second and third pillars. This paper identifies several efficiency aspects that can be improved in areas such as investment rules, price controls, performance benchmarking, switching rules, and automatic assignation of undecided participants. However, similarly to other countries in the region, a complete overhaul of the design of the decumulation phase would be required. The rules allowing pension funds to offer annuities are poorly designed and may ultimately lead to insolvency and/or unintended transfers across cohorts, ultimately harming contributing workers and retirees. In addition, the menu of retirement products is probably too restricted and it is unable to meet the needs of retirees with different characteristics and degrees of risk aversion. ${ }^{1}$ Fortunately, no retirees from the second pillar will enter the decumulation phase for few years to come and this leaves the authority with adequate planning time to address the issue.

2. The reminder of this paper is structured as follows: Section II briefly describes the Bulgarian pension system; Section III briefly describes the industrial organization of the second and third pillars; Section IV discusses asset allocation and assesses the performance of the second and third pillars since inception; Section V assesses the degree of price distortions in the pension industry; Section VI focuses on select regulatory issues in the accumulation and decumulation phases; and policy conclusions follow in Section VII.

\section{BRIEF Description of the BUlgarian Pension System}

3. The Bulgarian pension system follows a multi pillar design, typical of other countries in the region. ${ }^{2}$ The Bulgarian pension system comprises a public social security scheme in the first pillar, mandatory defined contribution (DC) plans in the second pillar, and voluntary DC plans in the third pillar. Table 1 summarizes the key elements of the pension system.

4. The first pillar provides a basic earnings-related pension. The earnings-related public scheme in the first pillar is managed by the National Social Security Institute (NSSI) paying a defined benefit (DB) pension with a 1 percent accrual rate up to a maximum pension with an average target replacement rate of 40 percent. Mandatory contributions amount to 17 percent of wages paid, 60 percent by employers and 40 percent by employees. ${ }^{3}$ Old age

\footnotetext{
${ }^{1}$ While the note starts analyzing the system from the accumulation phase, the reader interested in the decumulation phase only can skip to Section V.

${ }^{2}$ See Appendix I for a brief description of the second and third pillar prepared by the FSC.

${ }^{3}$ The ratio is to decline to 50:50 in 2010 .
} 
benefits from the first pillar are indexed according to the Swiss indexation rule (50 percent inflation +50 percent of earnings increase).

Table 1. Key Features of the Bulgarian Pension System

\begin{tabular}{|c|c|c|c|c|c|c|c|c|}
\hline \multicolumn{4}{|c|}{ Target Group /1 } & \multicolumn{5}{|c|}{ Key features } \\
\hline Pillar & $\begin{array}{l}\text { Lifetime } \\
\text { Poor }\end{array}$ & $\begin{array}{l}\text { Informal } \\
\text { Sector }\end{array}$ & $\begin{array}{l}\text { Formal } \\
\text { Sector }\end{array}$ & Institution(s) & Participation & Contributions & Financing & $\begin{array}{l}\text { Target Gross } \\
\text { Replacement } \\
\text { Rate /2 } \\
\end{array}$ \\
\hline 0 & 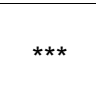 & ** & * & $\begin{array}{l}\text { Means tested } \\
\text { social pension }\end{array}$ & Universal & Non-contributory & y Budget & $\begin{array}{c}\text { Min BGL } 84.12 \text { per } \\
\text { month } / 2\end{array}$ \\
\hline 1 & & & $\star \star \star ~$ & $\begin{array}{l}\text { Social Security } \\
\text { (NSSI, NRA) }\end{array}$ & Mandated & $\begin{array}{c}17 \% \\
(60: 40)\end{array}$ & $\begin{array}{l}\text { DB, } \\
\text { PAYG }\end{array}$ & $40 \% / 2$ \\
\hline \multirow[t]{2}{*}{2} & & & $\star \star \star *$ & $\begin{array}{c}\text { Universal pension } \\
\text { funds (UPF, PIC, } \\
\text { NRA) }\end{array}$ & Mandated & $\begin{array}{c}5 \% \\
(60: 40)\end{array}$ & DC & $20 \%$ \\
\hline & & & $\star \star \star$ & $\begin{array}{c}\text { Professional } \\
\text { pension } \\
\text { funds (PPF, PIC, } \\
\text { NRA) }\end{array}$ & Mandated & $\begin{array}{c}12 \%, 7 \% \\
(100: 0)\end{array}$ & DC & $N / A$ \\
\hline 3 & * & $\star \star \star ~$ & $\star \star \star ~$ & $\begin{array}{c}\text { Voluntary pension } \\
\text { funds (VPF, OPF, } \\
\text { PIC) }\end{array}$ & Voluntary & N/R & DC & $N / R$ \\
\hline
\end{tabular}

Sources: Adapted from Holzmann et al. (2005), Page 10; Whitehouse (2007).

1/ The number of asterisks denotes increasing importance for each target group; $2 /$ Percentage of individual preretirement gross earnings for average earner; 3/ Since January 7, 2008 the minimum amount of contributoryservice and retirement-age pension is BGL113.49 and the amount of the social old-age pension is BGL 84.12.

5. The second and third pillars comprise mandatory and voluntary defined contribution pension funds. The second pillar covers two types of funds: (1) mandatory universal defined contribution (DC) pension funds (UPFs), introduced in 2002 for individuals born after 1959; and (2) professional DC pension funds (PPF) for special categories of labor (hazardous conditions), introduced in the year 2000. The third pillar also covers two types of DC funds, but in this case voluntary: (1) voluntary personal pension funds operating since 1994 (VPF); and (2) occupational pension funds (OPF) for voluntary group policies operating since 2007. These last funds stem from the transposition of the EC Directive 2003/41 (IORP Directive). No OPFs were active in Bulgaria at the end of 2007.

6. Pension funds are managed by specialized joint stock companies known as "pension insurance companies." Funds in the second and third pillars are managed by a pension firm, known in Bulgaria as "pension insurance company" (PIC). PICs are joint stock companies and are separate legal entities from the funds with a minimum capital requirement of BGL2.5 million (EUR1.3 million). Each PIC can only manage one fund of each of the aforementioned types and in relationship with third parties each fund is represented by the PIC managing it.

7. Mandatory contributions to the second pillar are low and target an average replacement rate of 20 percent. Contributions are centrally collected by the National Revenue 
Authority (NRA). Mandatory contributions to UPFs amount to 5 percent of wages paid with the employer responsible for 60 percent of that percentage and the employee for the other 40 percent. ${ }^{4}$ Self employed individuals must pay the entire 5 percent. Mandatory contributions to PPFs are fully paid by employers and amount to 12 percent for category I workers and 7 percent for category II workers. These contributions target an average replacement rate of 20 percent, in addition to the target replacement rate of 40 percent of the first pillar. ${ }^{5}$

8. The tax regime in the second and third pillars broadly follows an EEE regime. Mandatory contributions are tax exempt for both the employer and employee while voluntary contributions are tax exempt up to 10 percent of wage for the employee and BGL 60 for the employer. Investment income and retirement benefits are also tax exempt.

\section{MARKet STRUCTURE}

9. As of December 2007, 9 PICs were operating in the Bulgarian second and third pillars. ${ }^{6}$ Table 2 reports basic information ${ }^{7}$ on the number of legal entities operating in the second and third pillars in the period 2003-07. The market is fairly stable with mergers and acquisitions offsetting the impact of new entrants until 2007. In 2003, "BPOD” JSC was acquired (through merger by acquisition) by PIC "Doverie" JSC, and each of the funds, managed by "BPOD" JSC was acquired (through merger by acquisition) by the respective fund, managed by PIC “Doverie” JSC. In August 2003 "DZI” JSC was licensed and later changed its name to PIC “Budeshte” JSC. In August 2006, PIC “Toplina” JSC received a pension license. Since March 2007 the company manages a universal, a professional and a voluntary pension funds. On February 28th, 2008 "PENSIONNOOSIGURITELEN INSTITUT" JSC was granted a pension license, but it had not started operating at the time of writing.

Table 2. Number of Legal Entities

\begin{tabular}{lcccccc}
\hline & Unit & 2003 & 2004 & 2005 & 2006 & 2007 \\
\hline Total PIC & 1 & 8 & 8 & 8 & 8 & 9 \\
Total UPF & 1 & 8 & 8 & 8 & 8 & 9 \\
Total PPF & 1 & 8 & 8 & 8 & 8 & 9 \\
Total VPF & 1 & 8 & 8 & 8 & 8 & 9 \\
\hline
\end{tabular}

Source: FSC.

\footnotetext{
${ }^{4}$ The ratio is to change to $50: 50$ in 2010 .

${ }^{5}$ The lower than OECD average gross replacement rate is partly due to the low retirement age. The state retirement age for women is being raised to 59.5 in 2008 and then to 60 in 2009. The gross replacement rate from UPFs for new entrants in 2010, when the mandatory retirement age will be increased to 63 years for males and 60 years for female, is estimated at 15.4 percent for male and 11.8 percent for female (Ivanova, 2007). The average earner the OECD is 58.7 percent (AON 2007).

${ }^{6}$ As of June 2008, there were 10 licensed PICs, managing 29 funds in total. 7 PICs manage 1 UPF, PPF, and VPF each and 2 PICs manage 1 UPF, PPF, VPF and OPF each.

${ }^{7}$ Calculations assume equal capital for all PICs.
} 
10. The shareholders of Bulgarian PICs are concentrated in the non-financial sector, limiting the channels of eventual contagion among financial sector firms. Only 22 percent of paid-up capital is provided by financial sector companies while the rest is provided by nonfinancial companies (Table 3). The specific shareholding structure of Bulgarian PICs limits the possibility of contagion among financial sector firms through funding to the parent company. However, exactly the large presence of non-financial sector shareholders raises concerns about the ability of PICs to develop good risk management culture.

Table 3. Direct Shareholding Structure of PICs

\begin{tabular}{|c|c|c|c|c|}
\hline & $\begin{array}{l}\text { Pension Insurance } \\
\text { Company }\end{array}$ & $\begin{array}{c}\text { Shareholders } \\
\text { (more than } 10 \text { percent) }\end{array}$ & $\begin{array}{c}\text { Percent } \\
\text { of } \\
\text { Capital }\end{array}$ & Type \\
\hline 1. & ING & "ING Continental Europe Holding" & 100 & Financial Institution \\
\hline \multirow[t]{2}{*}{2.} & Pension Institute AD & Pela Eood & 74 & Non-financial Company \\
\hline & & EST Ad & 25 & Non-financial Company \\
\hline \multirow[t]{6}{*}{3.} & Budeshte Ad & "InterhotelL Sandskil-Bulgaria" Ad & 25 & Non-financial Company \\
\hline & & "Universe Company" Ood & 15 & Non-financial Company \\
\hline & & "Golden Union" Ood & 15 & Non-financial Company \\
\hline & & "Ceramic_Style" Ood & 11.4 & Non-financial Company \\
\hline & & "Beta Trading Corporation" Ood & 10 & Non-financial Company \\
\hline & & "East Trade Corporation" Ood & 10 & Non-financial Company \\
\hline \multirow[t]{2}{*}{4.} & CKB-Sila Aa & CKB Group Assets Manament Ead & 89.26 & Financial Institution \\
\hline & & Central Cooperative Bank Ad & 9.95 & Financial Institution \\
\hline 5. & Lukoil Grant-Bulgaria Ad & Chimimport Invest Ad & 84.60 & Non-financial Company \\
\hline \multirow{2}{*}{6.} & Allianz Bulgaria Ad & Allianz Bulgaria Holding Ad & 65.40 & Financial Institution \\
\hline & & National Electricity Company Ead & 34.00 & State Power Company \\
\hline \multirow[t]{2}{*}{7.} & Toplina Ad & L M Impex Eood & 46.40 & Non-financial Company \\
\hline & & Brikel Ead & 30.00 & Non-financial Company \\
\hline \multirow[t]{2}{*}{8.} & Doverie Ad & "BZP Ggroup" Ad & 80.29 & Non-financial Company \\
\hline & & $\begin{array}{l}\text { Insurance and reinsurance company } \\
\text { "Bulstrad" Ad }\end{array}$ & 12.29 & Financial Institution \\
\hline 9. & DSK-Rodina Ad & Bank DSK Ead(OTP group) & 97.00 & Financial Institution \\
\hline \multirow[t]{2}{*}{10.} & Saglasie Ad & Chimimport Ad & 49.28 & Non-financial Company \\
\hline & & Finance Consulting Ead & 19.09 & Non-financial Company \\
\hline
\end{tabular}

1/ As of May 30, 2008.

11. Membership in the two pillars is low but increasing with new entrants in the labor force. ${ }^{8}$ Second and third pillar coverage in 2007 was 99 percent of the labor force. This share is likely to include double counting of VPF accounts and therefore, it overestimates coverage of the labor force. A better indicator is the coverage of UPFs in the second pillar which was only 75 percent in 2007. The coverage of the Bulgarian pension system (like most countries in the region) is much higher than the coverage in countries in Latin America and it reflects the much lower size of the informal sector typical of the Easter European Region. Nevertheless, current numbers reflect the recent establishment of the second pillar in Bulgaria and the fact that only individuals born after 1959 are mandated to participate in the second pillar. It is expected that coverage will further increase with new entrants in the labor force and exit of

\footnotetext{
${ }^{8}$ See Appendix II with detailed data by legal entity.
} 
the cohorts not mandated to participate in the second pillar. Between 2003 and 2007, coverage of UPFs in the second pillar increased from 49 percent to 75 percent.

Table 4. Membership Growth and Concentration

\begin{tabular}{lcccccc}
\hline & Unit & 2003 & 2004 & 2005 & 2006 & 2007 \\
\hline Total PIC & 1 & $2,294,966$ & $2,716,367$ & $2,971,839$ & $3,201,326$ & $3,440,814$ \\
(Percent labor force) & percent & 69.90 & 81.76 & 89.62 & 93.72 & 98.51 \\
Total UPF & 1 & $1,613,875$ & $2,004,776$ & $2,239,512$ & $2,442,701$ & $2,640,652$ \\
Total PPF & 1 & 164,943 & 176,175 & 182,476 & 192,843 & 207,357 \\
(Percent labor force) & percent & 54.18 & 65.64 & 73.04 & 77.16 & 81.54 \\
Total VPF & 1 & 516,148 & 535,416 & 549,851 & 565,782 & 592,805 \\
\hline C2 PIC & percent & 68.88 & 64.70 & 63.33 & 62.32 & 59.77 \\
C2 UPF & percent & 66.99 & 62.16 & 60.63 & 59.80 & 57.43 \\
C2 PPF & percent & 64.50 & 62.00 & 60.11 & 57.99 & 53.52 \\
C2 VPF & percent & 76.17 & 75.10 & 75.39 & 74.66 & 72.41 \\
\hline HHI PIC & 1 & $2,728.91$ & $2,451.45$ & $2,369.53$ & $2,317.05$ & $2,184.88$ \\
HHI UPF & 1 & $2,890.45$ & $2,488.99$ & $2,372.08$ & $2,315.90$ & $2,191.01$ \\
HHI PPF & 1 & $2,704.67$ & $2,509.21$ & $2,410.34$ & $2,309.66$ & $2,063.65$ \\
HHI VPF & 1 & $3,268.61$ & $3,155.79$ & $3,152.92$ & $3,079.44$ & $2,917.01$ \\
\hline SOUI
\end{tabular}

Source: Own calculations on FSC data.

12. Accumulated net assets in the second and third pillars are also low but rapidly increasing. Total assets reached in 2007 nearly 3 percent and 1 percent of GDP for the second and third pillars, respectively (Table 5). The reason for the low asset base is mainly due to the low initial coverage and the low level of contributions. In addition, the level of 5 percent in mandatory contributions was reached only in 2007, increasing by 1 percentage point per year starting with 2002. Notwithstanding the low share of total assets in GDP, this is expected to double by 2010-2012 as a consequence of increasing coverage and compounding in rate of return. 
Table 5. Net Assets Growth and Concentration

\begin{tabular}{lcccccc}
\hline & Unit & 2003 & 2004 & 2005 & 2006 & 2007 \\
\hline Total PIC & 1 & 510,544 & 787,414 & $1,112,122$ & $1,517,412$ & $2,318,379$ \\
(Percent GDP) & Percent & 1.47 & 2.03 & 2.60 & 3.07 & 4.10 \\
Total UPF & 1 & 114,058 & 261,125 & 440,844 & 707,898 & $1,228,362$ \\
Total PPF & 1 & 143,817 & 200,832 & 253,312 & 314,292 & 411,396 \\
(Percent GDP) & Percent & 0.74 & 1.19 & 1.62 & 2.07 & 2.90 \\
TOTAL VPF & 1 & 252,669 & 325,457 & 417,966 & 495,222 & 678,621 \\
\hline C2 PIC & Percent & 70.25 & 68.70 & 67.44 & 65.20 & 62.16 \\
C2 UPF & Percent & 66.68 & 65.24 & 63.92 & 61.94 & 60.01 \\
C2 PPF & Percent & 68.25 & 67.49 & 65.50 & 63.01 & 59.56 \\
C2 VPF & Percent & 73.01 & 72.22 & 72.33 & 71.24 & 67.62 \\
\hline HHI PIC & 1 & $2,701.01$ & $2,586.35$ & $2,511.69$ & $2,391.82$ & $2,233.66$ \\
HHI UPF & 1 & $2,753.12$ & $2,619.02$ & $2,505.26$ & $2,397.40$ & $2,279.16$ \\
HHI PPF & 1 & $2,865.59$ & $2,794.98$ & $2,692.00$ & $2,598.20$ & $2,383.14$ \\
HHI VPF & 1 & $3,392.57$ & $3,329.06$ & $3,422.43$ & $3,361.38$ & $3,150.90$ \\
\hline
\end{tabular}

Source: Own calculations on FSC data.

13. Annual contributions are also low but rapidly increasing. Similarly to net assets, total contributions in 2007 represented only slightly more than 1 percent of GDP. However, they are expected to rapidly increase with increased coverage and contribution base (Table 6).

Table 6. Annual Contributions Growth and Concentration

\begin{tabular}{lcccccc}
\hline & Unit & 2003 & 2004 & 2005 & 2006 & 2007 \\
\hline Total PIC & 1 & 183,723 & 251,474 & 308,215 & 392,289 & 629,288 \\
(Percent GDP) & Percent & 0.53 & 0.65 & 0.72 & 0.79 & 1.11 \\
Total UPF & 1 & 71,208 & 133,763 & 165,844 & 236,831 & 410,560 \\
Total PPF & 1 & 45,021 & 47,589 & 46,943 & 52,122 & 64,146 \\
(Percent GDP) & Percent & 0.34 & 0.47 & 0.50 & 0.59 & 0.84 \\
Total VPF & 1 & 67,494 & 70,122 & 95,427 & 103,337 & 154,582 \\
\hline C2 PIC & Percent & 61.15 & 60.27 & 56.75 & 53.79 & 50.28 \\
C2 UPF & Percent & 68.31 & 63.71 & 61.35 & 59.58 & 57.80 \\
C2 PPF & Percent & 80.06 & 76.75 & 72.96 & 69.42 & 63.77 \\
C2 VPF & Percent & 46.43 & 50.89 & 46.19 & 42.13 & 49.96 \\
\hline HHI PIC & 1 & $2,503.13$ & $2,415.06$ & $2,365.30$ & $2,199.46$ & $2,072.02$ \\
HHI UPF & 1 & $2,850.68$ & $2,551.64$ & $2,434.17$ & $2,347.48$ & $2,261.26$ \\
HHI PPF & 1 & $2,969.43$ & $2,734.86$ & $2,568.71$ & $2,435.82$ & $2,216.52$ \\
HHI VPF & 1 & $2,921.12$ & $3,222.93$ & $3,455.71$ & $2,891.86$ & $2,711.88$ \\
\hline Sorce: Ow
\end{tabular}

Source: Own calculations on FSC data.

14. The size of the third pillar is surprisingly high. As of 2007, VPFs represented 17 percent, 29 percent, and 21 percent of total PIC membership, accumulated net assets and annual contributions, respectively (Table 4, Table 5, and Table 6). This surprisingly high share is due to the fact that voluntary pension funds have been in operation since 1994 and that they capture participants born before 1959 who cannot participate in the second pillar. These represent almost one third of participants in the third pillar. 
Table 7. Assets of Autonomous Pension Funds in Select OECD and non-OECD Countries (Percent of GDP)

\begin{tabular}{|c|c|c|c|c|c|c|}
\hline Countries 1/ & 2001 & 2002 & 2003 & 2004 & 2005 & 2006 \\
\hline Australia & 56.42 & 52.22 & 50.46 & 76.37 & 85.10 & 94.29 \\
\hline Austria & 2.94 & 3.78 & 4.13 & 4.39 & 4.78 & 4.82 \\
\hline Belgium & 5.51 & 4.93 & 3.92 & 3.99 & 4.46 & 4.26 \\
\hline Canada & 49.14 & 48.47 & 47.34 & 48.13 & 50.29 & 53.39 \\
\hline Czech Republic & 2.27 & 2.73 & 3.11 & 3.59 & 4.16 & 4.57 \\
\hline Finland & 49.48 & 49.18 & 53.86 & 61.84 & 68.69 & 71.32 \\
\hline Germany & 3.44 & 3.49 & 3.64 & 3.80 & 4.04 & 4.24 \\
\hline Hungary & 3.89 & 4.46 & 5.21 & 6.83 & 8.45 & 9.72 \\
\hline Ireland & 43.81 & 34.48 & 39.91 & 42.24 & 48.36 & 49.93 \\
\hline Italy & 2.25 & 2.32 & 2.44 & 2.57 & 2.80 & 3.01 \\
\hline Japan & 18.41 & 17.07 & 19.68 & 19.38 & 23.03 & 23.37 \\
\hline Mexico & 4.28 & 5.19 & 5.83 & 6.25 & 9.94 & 11.48 \\
\hline Netherlands & 102.62 & 85.50 & 101.19 & 108.42 & 122.53 & 129.97 \\
\hline New Zealand & 14.69 & 13.02 & 11.28 & 11.34 & 11.34 & 12.44 \\
\hline Norway & 5.49 & 5.52 & 6.47 & 6.55 & 6.72 & 6.83 \\
\hline Poland & 2.43 & 3.85 & 5.33 & 6.77 & 8.72 & 11.14 \\
\hline Portugal & 11.47 & 11.48 & 11.75 & 10.54 & 12.75 & 13.65 \\
\hline Slovak Republic & 0.00 & 0.00 & 0.02 & 0.32 & 0.62 & 2.78 \\
\hline Sweden & 8.25 & 7.60 & 7.70 & 7.55 & 9.29 & 9.48 \\
\hline Switzerland & 104.36 & 96.75 & 103.57 & 108.21 & 119.10 & 122.09 \\
\hline United Kingdom & 72.46 & 59.16 & 64.81 & 68.06 & 79.14 & 77.09 \\
\hline United States & 71.54 & 63.29 & 72.55 & 73.77 & 72.43 & 73.73 \\
\hline OECD Average 2/ & 30.09 & 26.62 & 28.16 & 29.60 & 32.92 & 34.69 \\
\hline Argentina & 7.74 & 11.18 & 12.31 & 11.91 & 12.24 & 13.64 \\
\hline Bolivia & 11.49 & 14.47 & 18.47 & 19.56 & 21.82 & 20.59 \\
\hline Brazil & 14.28 & 14.06 & 15.43 & 15.88 & 16.53 & 15.27 \\
\hline Bulgaria /3 & 0.63 & 1.04 & 1.48 & 2.08 & 2.66 & 3.21 \\
\hline Chile & 53.33 & 55.07 & 58.16 & 59.08 & 59.35 & 61.01 \\
\hline Colombia & 6.03 & 7.71 & 8.90 & 10.40 & 13.69 & 14.83 \\
\hline Costa Rica & & & 15.23 & 15.99 & 19.17 & 20.28 \\
\hline Dominican Republic & & & 0.21 & 1.02 & 1.27 & 2.12 \\
\hline El Salvador & 5.56 & 7.42 & 10.45 & 13.58 & 17.10 & 18.96 \\
\hline Estonia & 0.03 & 0.20 & 0.88 & 1.90 & 2.90 & 3.74 \\
\hline Hong-Kong, China & 14.57 & 16.82 & 18.37 & 23.06 & 24.78 & 27.83 \\
\hline Indonesia & & 2.25 & 2.43 & 2.51 & 2.31 & 2.31 \\
\hline Kenya & 10.01 & 12.19 & 12.25 & 11.65 & 12.13 & $13.02 / 1$ \\
\hline Mauritius & 42.81 & 42.60 & 44.09 & 50.82 & 53.88 & $55.32 / 1$ \\
\hline Peru & 6.56 & 7.92 & 10.33 & 10.95 & 12.76 & 15.45 \\
\hline Uruguay & 5.63 & 7.28 & 11.01 & 11.86 & 12.93 & 13.39 \\
\hline Non-OECD Average /2 & 12.23 & 12.34 & 12.69 & 14.62 & 15.47 & 15.36 \\
\hline
\end{tabular}

Source: OECD (2007).

1/ The OECD data underestimate pension fund assets as in many OECD countries a large portion of pension assets are managed by insurance companies. If these were to be included in the calculations, the relative size of the Bulgarian pension market would appear even lower; 2/ Own calculations; /3 Includes VPFs. 
15. The size of the private pension market in Bulgaria is much lower than in most OECD countries but comparable with the market in countries that have recently reformed their pension system. Bulgaria reformed its pension system introducing a mandatory second pillar only in 2002. This explains the low coverage and penetration, as well as the rapid growth of the system. As shown in Table 7, the Bulgarian second and third pillars are comparable to the ones in countries that have also recently reformed their pension systems (relatively to Chile) like the $\mathrm{Czech}^{9}$ and the Slovak Republics, the Dominican Republic, Estonia, et cetera. At the same time, it is much lower than countries with a long tradition of funding and or DC systems like The Netherlands, Australia, the U.K. and U.S., or of countries that reformed earlier in the last century their pension systems like Chile, Bolivia, Costa Rica, and Hong Kong.

16. Concentration in the Bulgarian pension market is high but this has been recently decreasing when new PICs entered the market. As of 2007, the largest two PICs represented 60 percent, 62 percent and 50 percent of total PIC membership, accumulated net assets and annual contributions, respectively (Table 4, Table 5, and Table 6). The market is highly concentrated but concentration has been decreasing due to new entrants and loss of market share from the largest incumbent firms. This is shown by the Herfindahl-Hirshmann index (HHI) in the three aforementioned tables: the HHI has decreased from 2700 in 2003 to something between 2100 and 2200 for all the three variables considered. This value is still higher than the 1800 above which many jurisdictions block mergers with the aim of limiting abuse of dominant position.

Table 8. Concentration Indicators-Select Countries

\begin{tabular}{lccccccccccc}
\hline \multirow{2}{*}{ Country /1 } & \multicolumn{9}{c}{ Number of Plan Managers } & \multicolumn{5}{c}{ C2 (percent) /2 } \\
& Dec '98 & Dec '03 & Dec '04 & Dec '05 & Dec '06 & Dec '02 & Dec '03 & Dec '04 Dec '05 Dec '06 \\
\hline Argentina & 15 & 12 & 12 & 11 & 11 & 53 & 42 & 40 & 39 & 38 \\
Bolivia & 2 & 2 & 2 & 2 & 2 & 100 & 100 & 100 & 100 & 100 \\
Chile & 9 & 6 & 6 & 6 & 6 & 62 & 56 & 55 & 55 & 55 \\
Colombia & 8 & 6 & 6 & 6 & 6 & 77 & 51 & 51 & 51 & 52 \\
Costa Rica & 9 & 8 & 8 & 8 & 8 & 55 & 66 & 64 & 61 & 59 \\
El Salvador & 5 & 2 & 2 & 2 & 2 & 79 & 100 & 100 & 100 & 100 \\
Mexico & 14 & 13 & 13 & 16 & 21 & 52 & 44 & 42 & 39 & 35 \\
Peru & 4 & 4 & 4 & 5 & 4 & 85 & 59 & 59 & 57 & 61 \\
Dominican R. & & 8 & 8 & 7 & 7 & & 60 & 61 & 60 & 60 \\
Uruguay & 6 & 4 & 4 & 4 & 4 & 77 & 75 & 74 & 74 & 74 \\
Hungary & 38 & 18 & 18 & 18 & 19 & 43 & 44 & 44 & 44 & 44 \\
Bulgaria & & $\mathbf{8}$ & $\mathbf{8}$ & $\mathbf{8}$ & $\mathbf{9}$ & & $\mathbf{6 1}$ & $\mathbf{6 0}$ & $\mathbf{5 6}$ & $\mathbf{5 3}$ \\
Source: AIOS & & & & & & & & & & &
\end{tabular}

1/ See for comparison with similar data in Eastern European countries; 2 / C2 refers to the share of assets managed by the largest 2 administrators.

17. High concentration is typical of mandatory DC pension funds and, for the most part, concentration has increased over time through mergers and acquisitions. (Table 8) Industry

\footnotetext{
${ }^{9}$ The Czech Republic has no second pillar and therefore, comparability applies only between the two third pillars.
} 
concentration is particularly high in small countries, such as Bolivia and El Salvador, where two managers cover the entire market. In Bolivia, the government initially granted operating licenses for two pension administrators, with an exclusivity period of five years, through an international bidding process. In El Salvador, five pension fund managers were initially set up in 1998. Two years later, three of these merged and the license of a fourth one was revoked for operating without sufficient capital. In 2006, the two largest Chilean pension fund administrators managed about 73 percent of pension funds assets, which were equivalent to around 40 percent of GDP. This high concentration can be related to an intensive industry consolidation in the late-1990s. ${ }^{10}$ Argentina and Mexico show a more diversified market, while concentration in the latter country (as well as in Peru) declined recently due to regulatory changes that eased the entry of new comers. High concentration is also found in jurisdictions with mandatory DC pensions outside the Latin American region. ${ }^{11}$ In Hungary, the number of local mandatory provident funds declined from 38 in 1998, year after the pension reform, to 18 in 2004 while assets under management in the 6 largest funds averaged 83 percent over the same period (Impavido and Rocha 2006). In Poland, the three largest pension fund administrators accounted for about 64 percent of the assets under management in the system in 2005, while this share was about 76 percent for Slovakia in 2006. In general, trends towards higher concentration is typical of the asset management industry. Assets under management of the world's largest 500 fund managers, industry concentration has grown in recent years and the share of the largest 20 fund managers' increased from 29 percent in 1996 to 36 percent in 2004.

\section{Asset Allocation And InVestment Performance}

\section{A. Asset Allocation}

18. The asset allocation of Bulgarian PICs is broadly similar to that observed in OECD countries, with the exception of “Anglo Saxon” countries. (Figure 1) Bulgaria shares with most OECD countries the low exposure to equity but contrary to most OECD countries it displays a much lower exposure to government and corporate bonds and especially mortgage bonds. This is low by comparison with other OECD countries where this asset class has become popular for pension funds, due to its attractive return-risk characteristics, good liquidity, and relatively long durations.

19. The weight of equities in pension funds portfolio has been rapidly increasing as well as diversification in the Euro zone. (Table 9, Table 10, Table 11 and Figure 2) The portfolio allocation in equities has increased on average from around 4 percent to 30 percent for all pension funds between 2003 and 2007. Over the same period, government paper has

\footnotetext{
${ }^{10}$ In the early 1990s, a large number of small and mostly inefficient operators entered the market which unleashed an aggressive competition war and resulted in higher costs and inefficiencies. At the peak point in 1995, there were as many as 21 operators. The lack of viability of the small operators and changes in regulations led to a wave of mergers and acquisitions and, as of July 2007, six managers operate in Chile.

${ }^{11}$ While trends towards more concentration are the norm, more mature countries like Australia, the United Kingdom, and Sweden have a more diversified industry.
} 
decreased from 60 percent to 20 percent for UPFs and PPFs and to 10 percent for VPFs. This appears compatible with the long term investment horizon of pension funds. At the same time, diversification away from BGL has increased, especially in the Euro zone since 2007. Between 2003 and 2007 foreign assets of pension funds increased from zero to around 20 percent of total investments. The proportion of euro denominated assets (not shown in the table) is estimated at 90 percent.

\section{Figure 1. Asset Allocation in 2006 in Select OECD Countries}

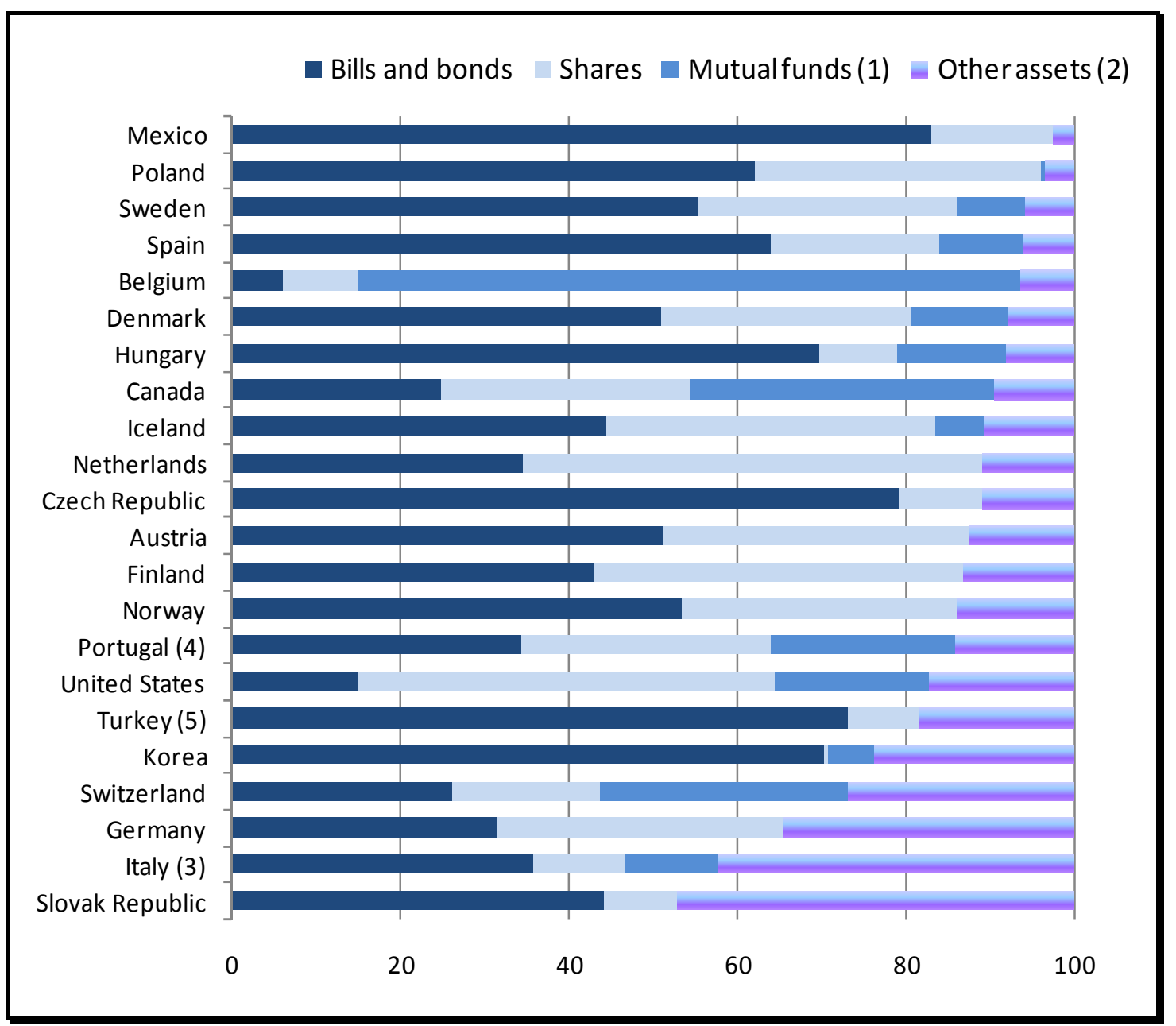

Source: OECD (2007).

1/ Mutual Funds (Collective Investment Scheme, CIS) comprise both retail and institutional funds (open-end and closed end). Institutional funds include a pooled vehicle that allows indirect investment into underlying assets such as equities and bonds. Further breakdown of assets classes invested through these pooled vehicles are not available 2/ The "Other" category includes cash and deposits, loans, land and buildings, unallocated insurance contracts, private investment funds and other investments. 
Table 9. Investment Portfolios of UPFs

\begin{tabular}{lcccc}
\hline UPF (Percent) 1/ & 2004 & 2005 & 2006 & 2007 \\
\hline Securities issued or guaranteed by the government & 57 & 55 & 32 & 18 \\
Securities, traded at regulated financial markets & 11 & 17 & 32 & 42 \\
$\quad$ Shares & 4 & 7 & 20 & 28 \\
$\quad$ Corporate bonds & 7 & 10 & 13 & 13 \\
Municipal bonds & 1 & 1 & 0 & 0 \\
Bank deposits & 19 & 17 & 22 & 16 \\
Mortgage bonds & 11 & 8 & 5 & 3 \\
Real estate & 0 & 0 & 1 & 2 \\
Derivatives & - & - & - & - \\
Investments abroad & 1 & 1 & 8 & 18 \\
Total investments (BGL 1000) & 260,538 & 434,045 & 667,475 & $1,189,905$ \\
\hline
\end{tabular}

Source: FSC

1/ Cash and receivables not included.

Table 10. Investment Portfolios of PPFs

\begin{tabular}{lcccc}
\hline PPF (Percent) 1/ & 2004 & 2005 & 2006 & 2007 \\
\hline Securities issued or guaranteed by the government & 57 & 56 & 33 & 18 \\
Securities, traded at regulated financial markets & 10 & 17 & 32 & 44 \\
$\quad$ Shares & 3 & 8 & 21 & 31 \\
$\quad$ Corporate bonds & 7 & 9 & 11 & 13 \\
Municipal bonds & 1 & 1 & 1 & 0 \\
Bank deposits & 19 & 16 & 21 & 15 \\
Mortgage bonds & 11 & 8 & 5 & 4 \\
Real estate & 2 & 0 & 1 & 3 \\
Derivatives & - & - & - & - \\
Investments abroad & 0 & 1 & 7 & 16 \\
Total investments (BGL 1000) & 260,538 & 434,045 & 667,475 & $1,189,905$ \\
\hline Source: FSC & & & &
\end{tabular}

1/ Cash and receivables not included.

Table 11. Investment Portfolios of VPFs

\begin{tabular}{lcccc}
\hline VPF (Percent) 1/ & 2004 & 2005 & 2006 & 2007 \\
\hline Securities issued or guaranteed by the government & 54 & 46 & 22 & 10 \\
Securities, traded at regulated financial markets & 10 & 17 & 34 & 41 \\
$\quad$ Shares & 3 & 7 & 22 & 32 \\
$\quad$ Corporate bonds & 7 & 9 & 13 & 9 \\
Municipal bonds & 0 & 0 & 0 & 0 \\
Bank deposits & 20 & 23 & 23 & 17 \\
Mortgage bonds & 12 & 11 & 7 & 4 \\
Real estate & 3 & 2 & 4 & 6 \\
Derivatives & - & - & - & - \\
Investments abroad & 1 & 1 & 10 & 21 \\
Total investments (BGL 1000) & 321,564 & 398,222 & 478,329 & 635,109 \\
\hline
\end{tabular}

Source: FSC

1/ Cash and receivables not included. 
Figure 2. Asset Allocation of Bulgarian Pension Funds, 2004-07

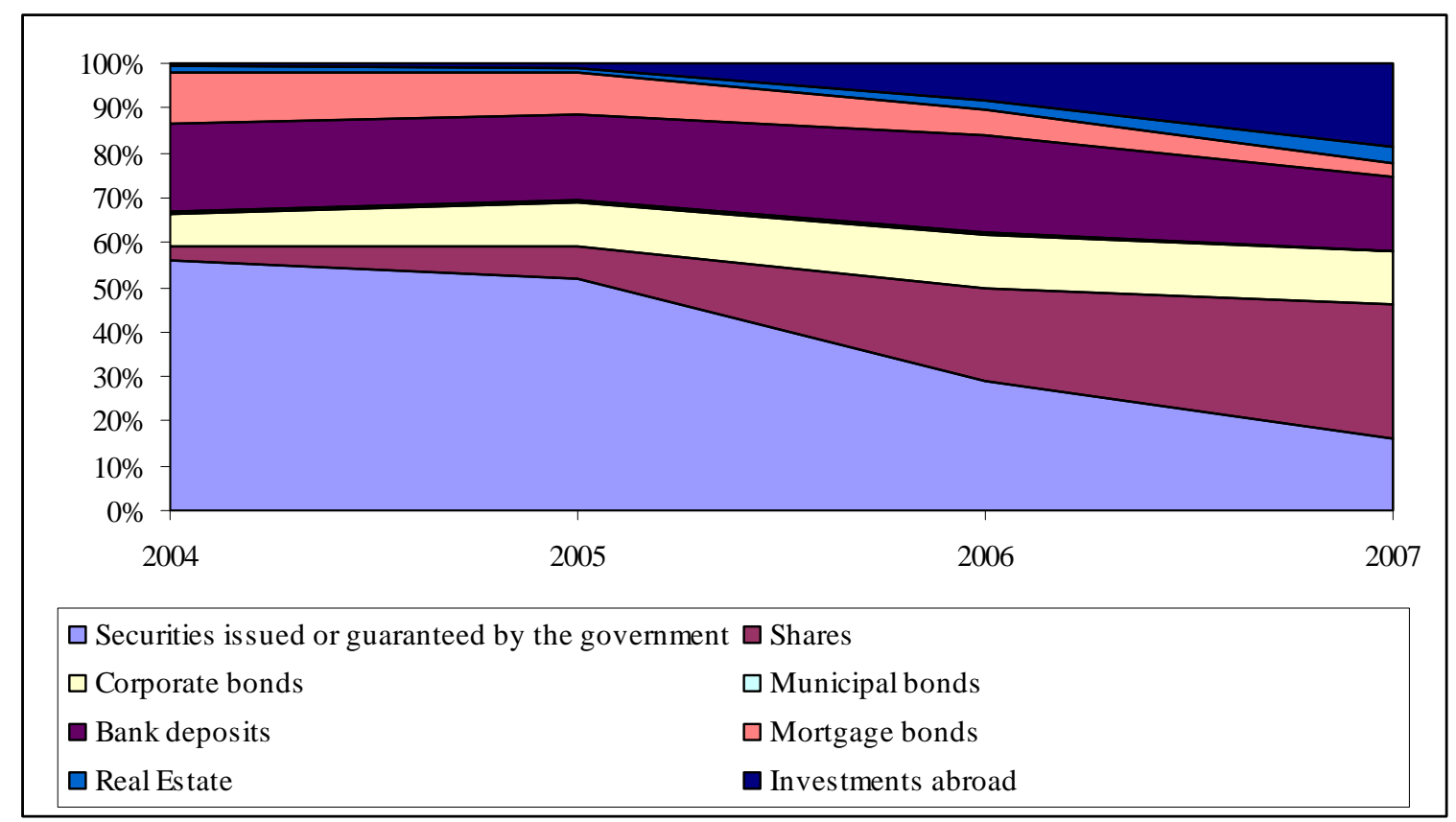

Source: FSC.

20. However, it is unclear whether the current allocation is efficient. The high share in bank deposits (20 percent) and the low share in mortgage bonds (3-4 percent), as well as other illiquid instruments cannot be easily explained. Pension funds in a mature system (where a fairly probable and constant volume of benefits need periodically paying) typically do not need more than 5 percent of assets in bank deposits. More generally, they do not need a high share of liquid instruments, unless there is a high number of switchers from one pension firm to the other. ${ }^{12}$ Larger holdings of illiquid instruments (and specifically, mortgage bonds) would improve long term performance of pension funds and at the same time, contribute to a reduction in maturity mismatches and exposure to interest risk by banks. Finally, foreign diversification in the Euro zone appears limited; but probably this is only due to the recent change in investment rules releasing restrictions in EUR denominated assets only as of 2007.

21. In addition, the duration of the bond portfolio is low caused by limited availability of long maturity instruments. The average maturity of government debt owned by PICs is around 9 years but this is much lower for other forms of debt, especially mortgage and corporate bonds (Table 8). The MaCauly duration of the bond portfolio of PICs is estimated by the FSC at $4-5$ years. This is partly due to the low availability of long duration instruments for pension funds which, in turn, is caused by investment rules that limit investment in potentially long duration instruments to those publicly traded in organized markets. For instance, only 12 mortgage bonds were traded at the time of writing on the

\footnotetext{
12 The churning rate of PICs' participants is only 2 percent: in comparison, the churning rate of Mexico reached almost 20 percent in 2006 (see page 38 for more information).
} 
Bulgaria Stock Exchange (BSE) with pension funds owning already 21 percent of their outstanding value of BGL 269 million. If these restrictions appear to limit investment opportunities in Bulgaria, they are not thought to be constraining investments in long term maturities in the Euro zone.

Table 12. Average Maturity of PICs' Bond Portfolio (March, 2007)

\begin{tabular}{lccc}
\hline & Currencies & $\begin{array}{c}\text { Number of } \\
\text { Issues }\end{array}$ & $\begin{array}{c}\text { Average } \\
\text { Maturity /1 }\end{array}$ \\
\hline Government bonds & BGL, EUR, US\$ & 41 & 9.41 \\
Corporate bonds & BGL, EUR & 72 & 4.47 \\
Municipal bonds & BGL, EUR & 4 & 6.25 \\
Mortgage bonds & BGL, EUR & 10 & 4.20 \\
\hline
\end{tabular}

Source: FSC

1/ Unweighted.

22. In summary, Bulgarian pension funds still play a relatively small role in the local capital market. For instance, pension funds own around 2 percent of total stock market capitalization of the BSE directly and another 1 percent indirectly through mutual funds. Additionally, the free float of the BSE is estimated at something between 15 percent and 25 percent of total market capitalization. This implies direct equity investments amount to anything between 8 percent and 14 percent of the free float while direct and indirect equity investments lie somewhere between 12 percent and 20 percent of the free float. Finally, annual turnover at the BSE due to PICs' direct and indirect investments decreased from around 13 percent to 6 percent between 2006 and 2007. Largely, PICs are "buy and hold" investors with very limited activity in the secondary market.

\section{B. Investment Performance}

23. Gross nominal returns have been high and increasing but the volatility of these returns has also increased, drastically reducing risk adjusted performance. For the period 2002-05 nominal returns in the second pillar, gross of administrative fees, averaged 10 percent per year with a standard deviation of 1.4. During 2002-07 they averaged (annualized average) 11 percent per year with a standard deviation of 3.2 (Table 13). The standard deviation for the period 2002-07 is on average three times higher than for the period 200205 . The increase in volatility is explained by the portfolio shift in equities that took place between 2006 and 2007. As a result of the increased volatility, risk adjusted nominal returns for the period 2002-07 are on average 60 percent lower than for the period 2002-05.

24. Gross real returns have also been high but not increasing over time due to the rapid increase in inflation. As shown in Table 13, gross real returns have been constant over the period 2002-07 due to the rapid increase in inflation experienced in the last part of the period. However, risk adjusted real returns decreased by less than nominal returns. Real risk adjusted returns in the 2002-07 period are on average only 15 percent than in the 2002-05 period due to the fact that average inflation and its volatility have increased. 
Table 13. Gross Nominal and Real Investment Performance, 2002-2007

\begin{tabular}{|c|c|c|c|c|c|c|c|c|c|c|c|}
\hline & Unit & 2002 & 2003 & 2004 & 2005 & 2006 & 2007 & $\begin{array}{c}\text { A.A. } \\
(03-05)\end{array}$ & $\begin{array}{c}\text { S.D. } \\
(03-05)\end{array}$ & $\begin{array}{c}\text { A.A. } \\
(03-07)\end{array}$ & $\begin{array}{c}\text { S.D. } \\
(03-07)\end{array}$ \\
\hline Average nominal UPF & Percent & 10.4 & 11.2 & 10.9 & 8.2 & 8.8 & 17.2 & 10.2 & 1.4 & 11.1 & 3.2 \\
\hline Average nominal PPF & Percent & 11.0 & 11.0 & 11.3 & 8.0 & 9.3 & 17.0 & 10.3 & 1.6 & 11.2 & 3.1 \\
\hline Average nominal VPF & Percent & 11.2 & 11.1 & 10.4 & 8.6 & 9.6 & 20.3 & 10.3 & 1.2 & 11.8 & 4.2 \\
\hline Average inflation & Percent & 5.8 & 2.2 & 6.3 & 5.0 & 7.3 & 8.4 & 4.8 & 1.9 & 5.8 & 2.1 \\
\hline Average real UPF & Percent & 4.6 & 9.1 & 4.6 & 3.1 & 1.5 & 8.8 & 5.3 & 2.6 & 5.2 & 3.0 \\
\hline Average real PPF & Percent & 5.2 & 8.8 & 4.9 & 2.9 & 2.1 & 8.6 & 5.4 & 2.5 & 5.4 & 2.8 \\
\hline Average real VPF & Percent & 5.4 & 8.9 & 4.0 & 3.6 & 2.3 & 11.9 & 5.5 & 2.4 & 6.0 & 3.7 \\
\hline
\end{tabular}

1/ Estimates except for inflation

Table 14. International Comparison of Real Rates of Returns

\begin{tabular}{|c|c|c|c|c|c|c|}
\hline \multirow[b]{2}{*}{ Countries } & \multicolumn{4}{|c|}{ Entire period } & \multicolumn{2}{|c|}{ Dec $2000-$ Dec 2005} \\
\hline & $\begin{array}{l}\text { Data } \\
\text { since }\end{array}$ & $\begin{array}{c}\text { Geometric } \\
\text { Mean Return }\end{array}$ & $\begin{array}{c}\text { Arithmetic } \\
\text { Mean Return }\end{array}$ & $\begin{array}{l}\text { Standard } \\
\text { Deviation }\end{array}$ & $\begin{array}{l}\text { Average } \\
\text { Return }\end{array}$ & $\begin{array}{l}\text { Standard } \\
\text { Deviation }\end{array}$ \\
\hline \multicolumn{7}{|c|}{ Latin America } \\
\hline Argentina (MP) & 1995 & 9.7 & 10.2 & 11.6 & 7.3 & 15.0 \\
\hline Bolivia (MP) & 1998 & 10.1 & 10.2 & 4.6 & 9.6 & 5.9 \\
\hline Brazil (VO) & 1995 & 5.7 & 5.9 & 6.3 & 2.7 & 4.8 \\
\hline Chile (MP) & 1982 & 9.5 & 9.8 & 8.5 & 6.1 & 2.7 \\
\hline Costa Rica (MP) & 2002 & 5.8 & 5.9 & 3.3 & 4.6 & 3.3 \\
\hline El Salvador (MP) & 1999 & 5.7 & 5.8 & 4.5 & 3.7 & 2.5 \\
\hline Mexico (MP) & 1998 & 7.3 & 7.3 & 3.8 & 6.5 & 4.0 \\
\hline Peru (MP) & 1994 & 14.3 & 14.6 & 8.8 & 15.0 & 6.1 \\
\hline Uruguay (MP) & 1997 & 14.7 & 15.3 & 13.0 & 19.2 & 16.4 \\
\hline \multicolumn{7}{|c|}{ Central and Eastern Europe } \\
\hline Czech Republic (VP) & 1995 & 1.0 & 1.1 & 1.6 & 1.5 & 1.5 \\
\hline Estonia (MP) & 2002 & 5.2 & 5.3 & 4.5 & 4.1 & 4.5 \\
\hline Hungary (MP) & 1998 & 2.3 & 2.4 & 5.4 & 3.1 & 5.8 \\
\hline Kazakhstan (MP) & 1999 & 7.9 & 8.4 & 12.7 & 2.3 & 5.3 \\
\hline \multicolumn{7}{|c|}{ North America } \\
\hline Canada (VO) & 1990 & 6.2 & 6.2 & 3.2 & 3.5 & 1.9 \\
\hline United States (DB) (VO) & 1988 & 7.1 & 7.5 & 9.6 & 1.5 & 13.9 \\
\hline \multicolumn{7}{|c|}{ Western Europe } \\
\hline Netherlands (QMO) & 1993 & 6.1 & 6.4 & 8.2 & 2.0 & 10.3 \\
\hline Sweden (QMO) & 1990 & 6.2 & 6.6 & 9.7 & 1.0 & 10.4 \\
\hline \multicolumn{7}{|c|}{ Asia-Pacific } \\
\hline Australia (MO) & 1990 & 8.9 & 9.1 & 5.7 & 4.9 & 8.4 \\
\hline Hong Kong (MO) & 2000 & 2.1 & 2.7 & 13.2 & 1.7 & 13.2 \\
\hline Japan (VO) & 1990 & 3.4 & 3.7 & 8.9 & 4.8 & 13.9 \\
\hline
\end{tabular}

Source: OECD-WB Private Pensions Performance Project.

25. However, gross real returns, particularly when adjusted for risk, have been higher than in other countries with mandatory DC systems in the region and comparable with top performers in Latin America. By comparing Table 13 and Table 14, it is possible to show that Bulgarian pension funds in the period 2000-05 performed in real terms better than most countries in the region like Hungary, Czech Republic, Estonia and Kazakhstan but worse than Poland and Croatia. Their performance is comparable to countries like Chile, Costa Rica and Mexico, among the top performers in Latin America. In addition, volatility of returns has 
been much lower in Bulgaria over the same period so that risk adjusted returns compare even better to the same set of countries. ${ }^{13}$

26. Notwithstanding, administrative fees have also been high. Average effective asset under management fee averaged 2.9 percent in the period 2003-05 and 2.7 percent in the period 2003-07. These figures were calculated by dividing "revenues from management fees" for PICs income statements by gross assets under management. ${ }^{14}$ By subtracting the effective fee charged by each fund from its nominal gross return, it is possible to analyze the net nominal return produced by each fund. Net nominal annualized average returns for UPFs increased from 6.7 percent in the period 2003-05 to 8.1 percent. Net nominal annualized average returns for PPFs increased from 8.0 percent in the period 2003-05 to 9.3 percent. Net nominal annualized average returns for VPFs increased from 8.0 percent in the period 200305 to 9.9 percent.

27. Incidentally, VPFs display higher nominal returns and lower fees than UPFs. Notice that UPFs and PPFs display very similar average gross nominal returns while VPFs show slightly higher nominal returns (Table 13). At the same time, PPFs and VPFs display effective fees expressed as a percentage of AUM that are on average lower by 100 basis points (Table 15) than fees charged by UPFs. This results in much higher net returns for VPFs and PPFs than UPFs for both the 2003-05 and 2003-07 periods analyzed. It is unclear why voluntary funds, which much lower scale, display higher net rates of return than mandatory funds UPFs or mandatory funds like PPFs with much smaller scale.

Table 15. Net Nominal Investment Performance, 2003-2007

\begin{tabular}{lccccccc|cccc}
\hline & Unit & 2002 & 2003 & 2004 & 2005 & 2006 & 2007 & A.A. & S.D. & A.A. & S.D. \\
& (03-05) & $(03-05)$ & $(03-07)$ & $(03-07)$ \\
\hline Average Eff. AUM Fee UPF & Percent & N/A & 3.7 & 3.5 & 3.0 & 2.6 & 2.6 & 3.4 & 0.3 & 2.8 & 1.0 \\
Average Eff. AUM Fee PPF & Percent & N/A & 2.3 & 2.1 & 1.9 & 1.7 & 1.7 & 2.1 & 0.2 & 1.8 & 0.5 \\
Average Eff. AUM Fee VPF & Percent & N/A & 2.2 & 2.1 & 1.8 & 1.6 & 2.3 & 2.0 & 0.2 & 1.8 & 0.4 \\
\hline Average Net Nominal UPF & Percent & N/A & 7.6 & 7.4 & 5.1 & 6.2 & 14.6 & 6.7 & 1.4 & 8.1 & 3.7 \\
\hline Average Net Nominal PPF & Percent & N/A & 8.7 & 9.2 & 6.1 & 7.6 & 15.4 & 8.0 & 1.7 & 9.3 & 3.5 \\
Average Net Nominal VPF & Percent & N/A & 8.9 & 8.3 & 6.8 & 8.0 & 18.0 & 8.0 & 1.1 & 9.9 & 4.6 \\
Average effective AUM fee /2 Percent & N/A & 3.6 & 2.6 & 2.4 & 2.3 & 2.4 & 2.9 & 0.7 & 2.7 & 0.6 \\
Average Wage Growth & Percent & 6.6 & 6.2 & 6.0 & 9.5 & 9.4 & 27.1 & 7.3 & 2.0 & 11.4 & 8.8 \\
\hline
\end{tabular}

Source: FSC, IMF (wage growth).

1/ Estimates except for AUM fee and wage growth; 2/ Own calculations.

28. As a result, net performance of the second pillar has been lower than the performance of the first pillar. For instance, Table 15 shows how net nominal returns have been lower than

\footnotetext{
${ }^{13}$ The table contains countries with very different industrial organizations of second pillars, investment rules as well as financial sectors at very different levels of sophistication and different GDP growth; all factors likely to affect the performance indicators.

${ }^{14}$ Year end figures were used instead of the more correct annual averages. Clearly, fees expressed as a share of average assets would appear even higher.
} 
nominal wage growth over the whole 2003-07 period. Wage growth is a measure of the implicit return in a balanced PAYG system and a common benchmark for assessing the performance of a second pillar. Only in 2003 and 2004 were net nominal returns higher than wage growth. For the period 2003-05 average wage growth (7.3 percent) exceeded net performance of the second pillar by at least 10 basis points. For the period 2003-07 average wage growth (8.8 percent) exceeded net performance of the second pillar by more than 220 basis points. This said, wage growth in the last part of this period was unusually volatile in Bulgaria and it has been growing from a very low base.

\section{Price Distortions}

29. Market concentration creates market power and important price distortions. The concern with concentration relates to the possibility that firms, through their exercise of market power, can create price distortions. ${ }^{15}$ Price distortions arise when a relative "markup", the ratio between the profit margin and the price, is imposed and therefore consumption takes place at distorted prices (higher prices relative to the competitive equilibrium).

30. Price distortions can be measured by the Lerner index. Price distortions can be measured by the Lerner index which is defined for each PIC as the relative difference between price and marginal costs. This is monotonically decreasing ${ }^{16}$ with the price elasticity of each firm's residual demand. For the market, the Lerner index is equal to the ratio of the $\mathrm{HHI}$ index and the price elasticity of the market demand. ${ }^{17}$

31. Price distortions in Bulgaria are comparable to other countries with a similar industrial organization. Table 16 compares concentration and market power ${ }^{18}$ in mandatory DC markets for select countries, including Bulgaria. In Mexico, the largest six companies represent more than 70 percent of the market in terms of registered individuals served or assets under management. Two distinct periods can be identified: a period of increasing concentration and average market power until 2003 and a period of decreasing concentration and market power afterwards due to a series of reforms aimed at increasing contestability and generally competition in the market. In Argentina, average relative mark-ups are much

\footnotetext{
${ }^{15}$ Market power creates distortions on both the demand and supply side. On the demand side, market power implies price distortions, losses in social welfare and rent redistribution from consumers to firms. On the supply side, distortions take the form of $\mathrm{X}$-inefficiencies and rent seeking behavior.

${ }^{16}$ More precisely: the Lerner index is inversely proportional to the elasticity of demand to prices. See Appendix IV for a detailed definition.

${ }^{17}$ See Appendix IV for a detailed definition.

${ }^{18}$ The Lerner Index has been approximated by using total costs instead of marginal costs. This approximation should not distort calculations if the marginal cost of servicing an extra customer is constant (constant marginal costs). The approximation underestimates market power in the presence of economies of scale (decreasing marginal costs). The pension business is thought to be characterized by high fixed costs and constant, if not decreasing marginal costs.
} 
lower ${ }^{19}$ than in Mexico; especially during the period 2002-2005, when the economic crisis severely hit the profitability of AFJPs.

Table 16. Concentration and Market Power-Select Countries

\begin{tabular}{|c|c|c|c|c|c|c|c|c|c|c|}
\hline $1 /$ & 1998 & 1999 & 2000 & 2001 & 2002 & 2003 & 2004 & 2005 & 2006 & 2007 \\
\hline \multicolumn{11}{|c|}{ Mexico } \\
\hline $\mathrm{HHI}$ & $1,317.8$ & $1,256.6$ & $1,232.3$ & $1,169.7$ & $1,424.2$ & $1,410.3$ & 1,336.6 & $1,209.2$ & $1,110.2$ & $1,092.5$ \\
\hline LI & (6.8) & 25.9 & 29.8 & 37.3 & 46.7 & 48.6 & 38.6 & 25.0 & 10.0 & 16.3 \\
\hline \multicolumn{11}{|c|}{ Argentina /1 } \\
\hline $\mathrm{HHI}$ & $1,281.7$ & $1,312.6$ & 1,298.3 & $1,542.1$ & $1,580.7$ & $1,549.8$ & $1,489.5$ & $1,431.7$ & $1,525.6$ & $1,508.6$ \\
\hline LI & 12.3 & 26.7 & 28.1 & 17.3 & $(0.6)$ & 0.4 & $(16.8)$ & (15.0) & 9.2 & 7.8 \\
\hline \multicolumn{11}{|c|}{ Chile } \\
\hline $\mathrm{HHI}$ & $1,577.5$ & $1,305.5$ & $2,066.3$ & $2,089.4$ & $2,090.8$ & $2,135.7$ & $2,140.0$ & $2,144.5$ & $2,147.0$ & $2,161.8$ \\
\hline $\mathrm{LI}$ & 11.3 & 13.7 & 32.2 & 36.6 & 39.2 & 30.2 & 34.0 & 31.4 & 35.4 & n.a. \\
\hline \multicolumn{11}{|c|}{ Peru } \\
\hline $\mathrm{HHI}$ & $2,292.8$ & $2,310.4$ & $2,660.6$ & $2,652.6$ & $2,646.8$ & $2,639.0$ & $2,628.7$ & $2,500.1$ & $2,666.9$ & $2,718.2$ \\
\hline LI & 8.6 & 20.9 & 45.4 & 52.2 & 52.8 & 51.8 & 54.8 & 24.6 & 9.2 & 12.3 \\
\hline \multicolumn{11}{|c|}{ Bulgaria } \\
\hline $\mathrm{HHI}$ & & & & & & $2,701.0$ & $2,586.4$ & $2,511.7$ & 2,391.8 & $2,233.7$ \\
\hline $\mathrm{LI} / 2$ & & & & & & (13.8) & $(4.2)$ & $(11.3)$ & 3.4 & 11.9 \\
\hline $\mathrm{LI} / 3$ & & & & & & 0.2 & 13.5 & 9.8 & 24.6 & 32.1 \\
\hline
\end{tabular}

Source: Own calculations for on FSC data.

1/ HHI calculated on assets under management; LI approximated with the use of average operational costs; 2/ Excluding income from own funds; 3 / including income from own funds.

32. The increasing trend in concentration and market power is also discernible in Peru. Pension funds charged on average a 50 percent relative mark up until 2004 and on average, they charged more than in Argentina. However, a sudden drop in profit margins took place after 2005 explained by the marketing war that followed the entrance of a new competitor in the previous year. In 2007, the increasing trend resumed with the merger of two incumbents, victim of the marketing war. In Bulgaria, PICs are on average more concentrated that in the other markets but market power is not as high as in the other countries. ${ }^{20}$ This is explained by the fact that PICs have not yet reached an efficient scale of production. In addition, PICs tend to subsidize operational costs through the income generated by their own funds. ${ }^{21}$ On

\footnotetext{
19 The Lerner index was calculated here by subtracting from both income fee and total costs the premium for disability and survivorship insurance. This will change from 2008 as a separate fund will be created for the purpose of purchasing insurance coverage.

${ }^{20}$ A direct comparison between Latin American AFPs should be made with PICs operational costs as they refer to UPFs only. Unfortunately, the FSC collects income data by type of fund but it does not disaggregate PICs operational costs by type of funds and therefore, it was not possible to calculate Lerner indices only for the PICs portion of the business that relates to the management of UPFs only.

${ }^{21}$ Since Bulgarian accounting standards for PICs do not separate operational costs by the type of fund, it was not possible to calculate measures of market power for the second pillar alone. In general, PICs appear to be subsidizing second pillar operations from income from the third pillar and own funds.
} 
average, operational profits derived from charges to participants amount to 12 percent of total fees in 2007 while these increase to 23 percent if income from own funds is included in the calculations. Market power and profitability are expected to increase with time if price caps are not reduced.

33. On average, price distortions in Bulgaria imply a highly profitable industry. The price distortions measured by the Lerner index imply a high profitability of PICs. Unfortunately, more traditional measures of profitability could not be measured. For instance, simple comparison of profits over assets are only an approximation of the "economic" rate of return on assets because the net return should be divided ideally by assets at replacement costs. This number is not reported here because it requires three adjustments that are outside the scope of this report. The first is to exclude assets not required by the business, such as financial investments, investments in other firms and investments in buildings that can be rented. The second is to add the replacement cost of intangible assets, which by convention are depreciated faster than what required by their actual economic life. The third is to add the expected cost of contingencies such as the penalty for violating the floor to relative returns, and the expected cost caused by unusual regulations such as an excessive capital requirement and excessive stabilization reserve, after optimization. An exercise where all this was done for Chilean pension administrators (that however, show higher Lerner Indices than Bulgaria) showed a return on assets of 50 percent per year for the five-year period 1999-2003 (ValdésPrieto and Marínovic, 2005).

\section{REgULATORY FRAMEWORK}

34. The Social Insurance Code (SIC) is the main legislative instrument regulating the public and private pension systems as well as social insurance in Bulgaria. The SIC is an Act of Parliament and establishes the rules for the licensing and the activity of the pension insurance companies, their supervision, the tax relief, the pension funding and the payment of pension benefits.

35. The SIC is complemented by secondary regulation issued by the FSC. Ordinances, instructions and guidelines for the licensing, operations and supervision of the private pension companies and private pension funds are issued by the FSC according to its powers set out in the Financial Supervision Commission Act (FSCA).

\section{A. Issues in the Accumulation Phase}

\section{Licensing}

36. Licensing criteria and procedures in Bulgaria are generally sound. The list of documents needed to obtain a license is contained in a dedicated FSC guidance note and includes the deed of foundation (minutes of proceedings and articles of association adopted at the founding meeting), the business plan of the fund for a three-year period, information on the members of the board of directors, the supervisory board, internal controls and auditing systems, data regarding the computer information system, pension schemes and products to be offered, and outsourcing draft contracts with any service provider, including custodians. 
37. License is granted separately for each fund. PICs may incorporate and manage only one universal, and one professional, one voluntary and one occupational pension fund. PICs are not obliged to establish and manage a pension fund of each type. The authorization is issued separately for each type of fund the company plans to establish and manage (article 122 SIC).

38. Restrictions exist on ownership of PICs that are de facto circumvented by the complex structure of Bulgarian and foreign groups. A shareholder cannot own more than one PIC. This restriction was introduced to limit the amount of income that any one shareholder could obtain through mandatory participation of an inert, and therefore, captive, clientele. This restriction is allegedly de facto breached for various PICs due to the complex structure of both financial and non financial groups operating in Bulgaria facilitating transactions with related parties.

39. The FSC plans to relax ownership restrictions but this should be compensated by a better definition of related parties. Ownership limitation rules are unenforceable unless the FSC has a complete mapping of the ownership structure of all groups operating in the country. As a consequence, plans exist for relaxation of ownership restrictions. At the same time, the FSC should strengthen the definition of related parties with which transactions are prohibited.

\section{Governance and risk management}

40. The two main governing bodies of a PIC are the managing board and the supervisory board. This two-tier board structure is relatively common in Continental Europe. In Company Laws (or Commercial Codes) the supervisory board is expected to represent the interests of shareholders and neutralize any influence of management on the main board. It plays a role similar to that of independent, outside directors in the one board systems prevalent in AngloSaxon countries.

41. The powers and responsibilities of the board of directors are generally sound but the current legislation does not foresee fit and proper standards for directors. The powers and responsibilities of the board of directors include implementing the resolutions passed at the general meeting, ensuring that the fund's books are kept in accordance with regulatory requirements and the fund's by-laws, approving the fund's investment policy and the method of asset valuation, and selecting other external service providers as needed. However, there are no fit and proper standards in the current legislation for directors, limiting the extent with which regulation ensures that PICs are managed by reputable and qualified individuals.

42. Pension funds are required to establish risk management units and develop risk management rules. Risk management culture at pension funds is in its early stages. Pension companies are trying to recruit risk management experts, but there is heavy competition for these experts from banks and insurance companies as well.

43. Directors are personally liable for omission, negligence or fraud but they are not required to take liability insurance. The members of the managing or of the supervisory boards of a PIC have personal and unlimited liability for any losses which are directly and 
immediately resulting from their omissions, negligence or fraud. However, they are not required to obtain personal liability insurance.

44. The FSC should consider requiring directors to purchase liability insurance. In light of the non-feasibility of identifying related parties beyond the direct or once removed relationship and the widespread complaints about related party transactions of three specific PICs in the market (Saglasie, CBK Sila and Lukoil Garant), the FSC should consider requiring directors to purchase liability insurance. This is already required from managers of insurance brokers and should be easily available within the Euro zone.

\section{Asset valuation rules}

45. Asset valuation of pension funds is conducted on a daily basis and rules are generally sound. Asset valuation rules for pension funds are contained in Ordinance No. 9 of 19.11.2003. The valuation of the assets and liabilities of a pension fund is performed every business day by the managing pension insurance company on the basis of: 1) information from the custodian bank for all completed transactions in the previous business day; 2) accounting record of the fund's liabilities and transactions with its assets for the previous business day; 3) information on the assets market price on the previous business day; and 4) determination of a fair value for assets which do not have a market price, by using applicable methods reviewed by the FSC. In general, when trading is infrequent, assets are valued by the lowest between the purchase price and the latest traded price, real estate is valued twice a year and capital gains and losses are split between realized and unrealized, but both are reflected in the individual accounts.

46. Asset valuation of PICs is conducted on a monthly basis and rules are generally sound. The assets and liabilities of pension insurance companies are valued in accordance with the Accountancy Act, the applicable accounting standards and Article 7 of the Ordinance No. 9. Assets in which the money from the reserves under Article 192 (2), Article 193 (8) and Article 213 (2) of the Social Insurance Code have been invested, are valued in accordance with the principles for valuation of assets under Section II of the Ordinance No. 9. The valuation of assets and liabilities of a pension insurance company is made on the first business day of each month.

\section{Investment regulation and introduction of life cycle funds}

47. Investment rules are fairly liberal and provide ample scope for geographical diversification in the Euro zone. ${ }^{22}$ Mandatory pension funds have no limitations regarding investment in bonds issued by the Bulgarian, EU or EEA governments, their central banks, the ECB, the EIB, as well as governments of third states defined by the FSC ${ }^{23}$ or their central banks. High limits also apply to investments in bank deposits (25 percent) and relatively high

\footnotetext{
${ }^{22}$ Investment rules for PICs are contained in the SIC (reported in Appendix III) and additional ordinances no 9 and 34. A summary of the investment rules is provided in Table 38.

${ }^{23}$ Essentially, all OECD countries plus Brazil, India and China.
} 
limits to mortgage bonds (30 percent). In addition, since January 2007, EUR and BGL denominated investments have identical investment limits allowing PICs to diversify their portfolios in the much deeper and liquid Euro zone market.

48. However, equity exposure is limited. For mandatory pension funds, direct equity exposure is limited to 20 percent of assets while investments in mutual funds are limited to 15 percent of assets. This implies a direct and indirect equity exposure limited to a maximum of 35 percent of assets. The current exposure limits to equity appear adequate, given the limited risk management capacity of especially the smaller PICs. However, they may not provide sufficient opportunities to increase expected returns through intertemporal risk diversification. Since participants are not totally reliant on the second pillar for their retirement income, there appears to be scope for allowing PICs to take greater risk ${ }^{24}$ in the second pillar.

49. Additionally, the law does not permit investment in infrastructure. Infrastructure investments are typically a useful long-term investment vehicle. This could also be the case in Bulgaria (provided there is confidence about the efficacy of property rights). Although the market is currently shallow, pension funds would be natural investors in these types of assets (given their long-term investment horizon) and the authorities should be alert to any opportunities which could arise. It is believed that a prudent way to authorize investment in infrastructure (due to the poor risk management capacity of pension firms) is not to allow pension fund managers to select investment projects directly but through the use of infrastructure funds that pool different projects together. Since these are unavailable in the country, this would be done through Euro zone-based infrastructure funds (similarly for venture capital and private equity funds).

50. Moreover, the law does not adequately define investment limits in structured products. Reportedly, PICs have started investing in capital guaranteed products, especially since the burst of the equity bubble at the end of 2007. However, structured products are not well defined in the investment regulations. For instance, capital guaranteed products are considered bonds. This means that PICs can circumvent the rules aimed at limiting exposure to share price volatility by exploiting the more relaxed investment limits for bonds. The FSC should review the investment regulations as to eliminate opportunities for PICs to circumvent existing quantitative limit in any asset class.

51. Also, rules allow for investment in derivatives for hedging purposes but do not specify important prudential criteria for monitoring the risks taken by investment managers. The transactions with derivatives that PIC could conclude in order to reduce the investment risk related to assets of pension funds are set up in art. 179b of the SIC. The detailed requirements for conclusion of such transactions are settled in the Ordinance No 34 of the FSC. While investment in derivatives is allowed for hedging purposes, it is unclear that current investment managers are generally qualified to invest in derivatives and whether the

\footnotetext{
${ }^{24}$ This does not mean that PICs should take unremunerated risks; it simply suggest that there is scope for moving up along the risk/return curve.
} 
FSC is equipped to monitor the use of derivatives. This is not an issue at present since PICs do not invest in derivatives. However, it may become one in the future. Jurisdictions like Mexico have introduced mandatory certification of investment managers as a precondition for investing in derivatives. In addition, they monitor that derivatives are used only for hedging purposes by periodically comparing portfolios' VaRs with and without derivatives. It is recommended that the FSC agrees with the industry on minimum certification standards for investment managers for trading in derivatives. In addition, the FSC would need to develop its own quantitative metrics to effectively monitor investment managers transactions in this asset class in the future.

52. Furthermore, PICs are not allowed to lend securities. Since PICs are long term investors with little need for highly liquid instruments in the short run, it is unclear why they are not allowed to lend securities. Securities' lending programs are fairly standardized and involve minimum risk. They generate income fee of few basis points to participants and promote the development of secondary markets. The key risk that needs managing is the counterparty risk, including the risk associated with the quality of collateral posted by the borrower against the securities loaned. Additionally, a lending program implies limited operational risk as daily reconciliation among program participants and compliance monitoring will be required. Market facilitators arrange and facilitate securities lending transactions. These include custodial banks, third party lending agents, broker-dealers acting as principals or as a securities lending manager. While, in principle a variety of agents can be used, it is preferred in the case of Bulgaria to use custodians for this purpose. Indeed, the FSC could require the custodian to manage all the risks related to the security lending activity that it is deemed not practical that the PIC manage in house. Since pension funds are reported to be "buy and hold" investors, securities lending appears an extremely practical for PICs to be involved providing large potential externalities for the rest of the capital market.

53. With few exceptions, investment rules contain generally sound measures aimed at mitigating concentration, liquidity and credit risk. Investment rules have a bias for instruments traded in organized markets for which prices can be easily established. In addition, they define clear credit rating limits. Finally, they define exposure limits by issuer in both percentage of issuer's assets or as a percentage of invested assets. In this sense, investment rules are designed to provide adequate safety and liquidity. However, few exception apply. For instance:

- $\quad$ Due to the bias for investments traded on organized markets, PICs cannot participate in IPOs. This severely limits investment opportunities for PICs as well as the development of the local equity market.

- While mandatory funds cannot invest more than 5 percent in any individual mutual fund manager, there are no restrictions regarding the share of any mutual funds that can be bought by a PIC. This could expose the mutual fund to large price pressures if any given PIC comes to represent too large an investor. It would be desirable that any given PIC would not represent more than 25 percent of total investments in any one mutual fund. 
- $\quad$ Also, European corporate bonds need to have investment grade credit rating but Bulgarian corporate bonds are exempt from this requirement, probably observing that few domestic issuers are rated.

54. Finally, investment rules do not allow for investment choices by participants. While the FSC is introducing life-style (as opposed to life-cycle) funds for VPFs a clear strategy needs developing for the introduction of adequate default options for mandatory funds. Currently, UPFs and PPFs participants have no investment choices despite modern portfolio theory provides scientific foundation and rationale for both "risk-based" and "age-based" asset allocation strategies that characterize life-style and life-cycle funds, respectively. Given the large accumulated evidence that the vast majority of mandatory DC plan participants shows considerable degree of inertia in contribution and investing decisions, any decision regarding investment choice would need to be accompanied by the introduction of adequate investment default options for inactive participants. The FSC would need to design default options, preferably on the basis of target date-life-cycle funds (as opposed to life-style).

\section{External audits}

55. Auditing rules and practices in the second pillar are generally reasonable, although there are still some specific gaps that would merit attention from the regulatory authorities. All individual auditors of financial institutions need to be registered and licensed to audit a particular type of institutions. However, there is no legal requirement for the auditors to be registered with the FSC and Art. 187, para. 1 of the Social Insurance Code (SIC) only requires that the auditors are registered according to the Independent Financial Audit Act by the Institute of the Certified Expert Accountants. In addition, individual auditors are not subject to a maximum number of years rotation rule and it is good practice to require either rotation of audit firms or to individual auditors within each firm. Reputable PICs are believed to rotate auditors every 3 to 5 years.

56. Auditing rules do not specify in detail the scope of the audit, but in practice they are considered sound when conducted by reputable international firms. Auditors review all financial statements, IT systems, internal controls, and the reconciliation of values with the custodian. Therefore, the scope of the audit looks generally reasonable. However, the FSC has little influence on the scope and standards of audits adopted by the association. More formally, the SIC does not empower the FSC to change/broaden the scope, according to special needs. The FSC should consider establishing a working group with the PICs' association and the audit profession to disseminate good audit practice also among local audit firms.

57. The external auditors can be used as whistle blowers in various circumstances. The supervisors can call the auditors for clarifications without need for approval of the pension fund board or management. In addition, the FSC has access to the auditors' working papers. Also, auditors have the legal obligation to report serious breaches of regulation and prudential guidelines directly to the supervisor but the definition of what constitutes a "serious breach" is not specific and therefore open to interpretation. Reporting obligations are more specific only in the case of suspected money laundering activities. Finally, while the 
FSC has formal sanctioning powers with respect to auditors, these sanctions seem to be ineffective due to the weak basis for determining liability in the auditing process.

\section{Asset segregation and custodianship}

58. Asset segregation rules are generally sound. Assets of all the legal entities in the second and third pillars must be physically segregated. The pension insurance companies and the pension funds are separate legal persons (art. 133 and art. 214 of the Social Insurance Code). According article 134 and 215 SIC the pension funds and their assets are not liable for any losses of the pension insurance company or for losses resulting from actions of the said company.

59. Rules on the use and role of custodians are also generally sound. All assets of a pension fund must be kept at an independent custodian bank on the basis of a contract for custodian services concluded between the PIC and the custodian bank. According to article 123a and 123b of the SIC, the contract with the custodian bank is to be submitted to the FSC. The FSC does not have the power to authorize a commercial transaction but would intervene at the level of the PIC's board if it believes that the custodian contract would represent a source of risks for the PIC.

60. Custodians are used as whistleblowers in select circumstances. The custodian bank cannot execute transactions involving investments in any assets other than the assets regulated in SIC. In addition, at the end of each working day, the custodian bank is required to transmit to the FSC information regarding the financial resources received, the transactions concluded and the assets of the supplementary pension fund. Finally, the custodian is required to inform the FSC of any detected violation of SIC by the pension insurance company. However, it is not required to inform the FSC of transactions that are potentially not in the interest of participants (involving, overpriced securities or excessive brokerage fees, for instance).

61. The regulations appear to limit excessively the role of custodians. Custodians provide various services to PICs including: settlement, corporate actions, custody and daily portfolio reporting to the FSC. They could also provide investment advice and market research but it is general practice of PICs not to purchase such services. However, regulation appears to limit the role of custodians in critical areas. For instance, custodians are not involved in the calculations of the NAV for fund portfolios. This could be provided at no cost by custodians and could represent an independent check and balance aimed at strengthening consumers' protection. Additionally, custodians cannot manage a securities lending program for PICs. Finally, custodians have no power to block investment transactions if these are in breach of regulations.

\section{Minimum return guarantee}

62. The specific design of the minimum pension guarantee in Bulgaria penalizes conservative investors and it is vulnerable to price pressures. The minimum pension guarantee is calculated as the 60 percent of the asset weighted average performance of the market in the previous 24 months. Asset weights are capped to 20 percent to control for 
manipulation of this shared benchmark. However, this entails that the benchmark is vulnerable to price pressure by smaller funds that invest heavily in risky assets at the expenses of more conservative investors. This is in partly due to the 20 percent cap on asset weights but it is principally due to the combination of three factors: the shallow Bulgarian capital market; the short maturity over which the average is calculated; and the fact that such average is not risk adjusted. Several participants advocate for the relaxation of the caps as a way to reduce the influence of smaller, aggressive funds on the benchmark. However, a more effective way to reduce the vulnerability of the benchmark to price pressures may be to extend the benchmark to 3 or 5 years and adjusting it for risk.

Table 17. Minimum Return Guarantee in Select Countries

\begin{tabular}{|c|c|c|c|c|}
\hline Country & Benchmark and Bands & $\begin{array}{l}\text { Assessment } \\
\text { Period }\end{array}$ & $\begin{array}{l}\text { Frequency } \\
\text { of Evaluation }\end{array}$ & $\begin{array}{l}\text { Disclosure of } \\
\text { Portfolios }\end{array}$ \\
\hline Argentina & $\begin{array}{l}\text { Min (70 percent of WSRA, WSRA } \\
-2 \text { percent) }\end{array}$ & 12 months & Monthly & \\
\hline $\begin{array}{l}\text { Colombia } \\
1 /\end{array}$ & $\begin{array}{ll}\text { A } & 70 \text { percent of WSRA } \\
\text { B } & 70 \text { percent of RSP } \\
& 70 \text { percent of Return of } \\
\text { BVC index } \\
\text { 70 percent of Return of } \\
\text { S\&P500 } \\
\text { Minimum Return }=(A+B) / 2\end{array}$ & 36 months & Quarterly & $\begin{array}{l}\text { Full disclosure after } \\
30 \text { days }\end{array}$ \\
\hline Chile & $\begin{array}{l}\text { Risky funds = } \\
\text { Min (50 percent of WSRA, WSRA } \\
-4 \text { percent) } \\
\text { Conservative funds = } \\
\text { Min (50 percent of WSRA, WSRA } \\
-2 \text { percent) }\end{array}$ & 36 months & Monthly & $\begin{array}{l}\text { Full disclosure after } \\
10 \text { days }\end{array}$ \\
\hline Poland 2/ & $\begin{array}{l}\text { Min (50 percent of WSRA, WSRA } \\
-4 \text { percent) }\end{array}$ & 36 months & Bi-annually & $\begin{array}{l}\text { Full disclosure } \\
\text { yearly; } \\
\text { Partial bi-annually }\end{array}$ \\
\hline $\begin{array}{l}\text { Slovak } \\
\text { Republic 3/ }\end{array}$ & $\begin{array}{l}\text { Conservative fund = Min (90 } \\
\text { percent of WSRA, WSRA } \\
-1 \text { percent) } \\
\text { Balanced funds = Min ( } 70 \text { percent } \\
\text { of WSRA, WSRA - } 3 \text { percent) } \\
\text { Growth funds = Min ( } 50 \text { percent of } \\
\text { WSRA, WSRA - } 5 \text { percent) }\end{array}$ & 24 months & Daily & $\begin{array}{l}\text { Full disclosure bi- } \\
\text { annually }\end{array}$ \\
\hline Lithuania & $\begin{array}{l}\text { Min (50 percent of WSRA, WSRA } \\
-2 \text { percent) } \\
\text { No Max }\end{array}$ & 36 months & Quarterly & Full disclosure \\
\hline Bulgaria 4/ & $\begin{array}{l}\text { Min ( } 60 \text { percent of WSRA, WSRA } \\
-3 \text { percent) } \\
\text { Max ( } 140 \text { percent of WSRA, } \\
\text { WSRA }+3 \text { percent })\end{array}$ & 24 months & Quarterly & Full disclosure \\
\hline
\end{tabular}

1/ WSRA: Weighted System Return Average; 2/ Changed in 2008; RSP: Return of the Synthetic Portfolio; BVC index: Bogotá Stock Exchange index; 3/ Weights have a 15 percent cap and shares of remaining funds are increased proportionally to reach 100 percent; 4/ Arithmetic mean of sliding average of percentage year-on-year changes of daily net asset values of the pension fund; 5/ Weights have a 20 percent cap and shares of remaining funds are increased proportionally to reach 100 percent. 
63. The minimum return guarantee is very different from the absolute return guarantee adopted in Switzerland or the guarantee adopted in Hungary. The absolute guarantee in Switzerland (3 percent p.a.) is backed by an industry-wide guarantee fund. This construction, similar to pension benefit guarantee schemes in defined benefit systems, and bank deposit insurance schemes prevalent in many countries, raises moral hazard issues that have not yet been satisfactorily addressed in Switzerland. In Hungary, the benchmark is not the industry's average return, nor an absolute return, but a rate of return target that is determined primarily by a basket of long-term Government securities. If the rate of return exceeds the upper band the excess would need to be placed in the liquidity reserve. If the rate of return is lower than the lower band it should be increased to the minimum with transfers from the liquidity reserve. The liquidity reserve cannot be larger than 4 percent of total assets. Therefore, the rate of return guarantee in Hungary seems an internal smoothing device, designed to avoid extreme fluctuations relative to the benchmark.

64. The minimum return guarantee is similar to the one present in most other countries that adopted mandatory DC pensions. In Chile, and most other countries that adopted the Chilean system, the minimum return guarantee is relative-defined in relation to a band around the average rate of return of all pension funds over a rolling 36 month period. If the rate of return is lower than the lower band, the asset manager needs to make up for the difference from its own minimum reserves. If the return is higher than the upper band, the difference is placed in a profitability reserve in the pension fund ${ }^{25}$ (Table 17). The extreme herding by pension funds in Chile has led to very similar returns, implying that profitability reserves have not been built, nor asset managers have had to use their own minimum reserves to increase returns to the minimum.

65. In Bulgaria, the minimum return guarantee has not yet generated herding. Minimum return guarantees like the one adopted in Bulgaria, while providing an effective benchmark for monitoring and comparing performance, they are often criticized for generating investment herding. However, herding among Bulgarian pension fund has been low as shown by the heterogeneous portfolio allocation and nominal performance. ${ }^{26}$ The top portion of Table 18 reports the average standard deviation in the portfolio weights of pension funds for different asset classes. Notice that funds have very different weights in asset classes like government debt and securities traded in organized markets, like equities. In particular, the market is divided in two groups of funds: a group of conservative (large) pension funds with portfolio allocations skewed towards government paper and more diversified abroad and a group of (small) pension funds with portfolio allocations increasingly skewed over time towards equities and less diversified abroad. Funds tend to have very similar (and

\footnotetext{
${ }^{25}$ According to Article 193, paragraph 7 of the Social Insurance Code (SIC) where the rate of return achieved by a universal or a professional pension fund exceeds by over 40 percent the average rate of return achieved for the respective type of pension fund or exceeds the average by 3 percentage points, whichever of the two figures is greater, the resources resulting from return above this percentage shall be set aside for a reserve by the respective fund.

${ }^{26}$ Raddatz and Schmukler (2008) discuss alternative tests for static and dynamic herding tha could not be used here with the data available.
} 
increasingly so) weights in municipal bonds, mortgage bonds and corporate bonds. The bottom portion of Table 18 reports the standard deviation of realized nominal returns across pension funds. Notice, that compatibly with portfolio heterogeneity, realized performance has been increasingly different for all pension funds in the period between 2002 and 2006. While this trend continued for VPFs in 2007, mandatory funds have performed in a more homogeneous way in the same year.

Table 18. Standard Deviation in Portfolio Weights and Returns of PICs

\begin{tabular}{lcccccc}
\hline & 2002 & 2003 & 2004 & 2005 & 2006 & 2007 \\
\hline Securities issued or guaranteed by the government & N/A & N/A & 13 & 14 & 6 & 11 \\
Securities, traded at regulated financial markets & N/A & N/A & 5 & 5 & 7 & 12 \\
$\quad$ Shares & N/A & N/A & 4 & 2 & 5 & 9 \\
$\quad$ Corporate bonds & N/A & N/A & 5 & 6 & 5 & 5 \\
Municipal bonds & N/A & N/A & 1 & 1 & 1 & 0 \\
Bank deposits & N/A & N/A & 9 & 7 & 5 & 7 \\
Mortgage bonds & N/A & N/A & 6 & 6 & 4 & 3 \\
Real estate & N/A & N/A & 2 & 1 & 3 & 2 \\
Derivatives & N/A & N/A & - & - & - & - \\
Investments abroad & N/A & NA & 2 & 2 & 6 & 12 \\
\hline UPF nominal return & 2.44 & 1.68 & 1.96 & 1.39 & 5.36 & 3.99 \\
PPF nominal return & 0.97 & 1.05 & 2.07 & 1.16 & 5.11 & 2.84 \\
VPF nominal return & N/A & 1.02 & 1.63 & 1.33 & 4.40 & 6.57 \\
\hline Sourc: Omm calcur
\end{tabular}

Source: Own calculations.

\section{Price controls}

66. Bulgaria has introduced price controls following a general trend in the region and elsewhere. Bulgaria caps the charges on the flow to 5 percent of contributions and on the stock to 1 percent of asset under management for UPFs and PPFs. For VPFs, caps are 7 percent of contributions and 10 percent of investment income. The use of price controls is common in both developed and less developed economies but it is usually limited to mandatory funds as the low price elasticity of the demand is very low and, consequently the market power of pension fund manager high. It is unclear why there should be price control to voluntary funds where the price elasticity of demand is typically much higher (individuals opt to participate). Countries in the region that have introduced price controls are Croatia, Poland, Slovak Republic, Macedonia, Romania, Kazakhstan. Other countries in Latin America include Bolivia, Colombia, Costa Rica, Dominican Republic and El Salvador. Countries in Europe that use price controls include Sweden and the U.K.

67. Or alternatively, Bulgarian pension funds have a forty year asset management equivalent fee of 1.2 percent. The asset management equivalent fee is derived so as to have the same impact on final cash balances to the current complex fee structure. The asset management equivalent asset fee is calculated as the annualized charge over assets that would have generated exactly the same final cash balance as the actual combination of charges on contributions, assets and returns applied to the individual retirement account of a 
representative consumer during a given period of time (say, 25 and 40 years). ${ }^{27}$ In Bulgaria, the current combination of charges on the flow and on the stock is equivalent to a 1.2 percent asset management fee projected for the next 40 years.

Table 19. Price Regulation in Select Countries

\begin{tabular}{lccc}
\hline & $\begin{array}{c}\text { Percent of } \\
\text { Contributions 1/ }\end{array}$ & $\begin{array}{c}\text { Percent of } \\
\text { Assets }\end{array}$ & $\begin{array}{c}\text { Percent of Excess } \\
\text { Return Over } \\
\text { Benchmark }\end{array}$ \\
\hline Bolivia & 5 & 0.23 & $\ldots$ \\
Colombia & 30 & $\ldots$ & $\ldots$ \\
Costa Rica & 4 & $\ldots$ & $82 /$ \\
Dominican Republic & 6 & $\ldots$ & $303 /$ \\
El Salvador & 13 & $\ldots$ & $\ldots$ \\
Macedonia & 6 & 0.5 & $\ldots$ \\
Poland & $\ldots$ & 0.54 & $\ldots$ \\
Slovakia & 1 & 0.075 & $\ldots$ \\
Hungary & 5 & 0.8 & $\ldots$ \\
Bulgaria UPF, PPF & $\mathbf{5}$ & $\mathbf{1}$ & $\mathbf{1 0} 2 /$ \\
Bulgaria VPF & $\mathbf{7}$ & $\ldots$ & \\
\hline Source:
\end{tabular}

Source: own calculations on country regulation.

1/ One in many Latin America countries caps are expressed as a percentage of earnings. In this table we divided those caps by the contribution rate to express them as a function of the levels of contributions; $2 /$ In Costa Rica, Poland and Bulgaria the benchmark is zero so that the performance fee becomes a fee on nominal returns; $3 /$ In Dominican Republic, the benchmark is close to the return on bank deposits making the performance fee an asset management fee in disguise.

68. In spite of price controls, Bulgarian PICs charge one of the highest level of administrative fees among countries with a similar second and third pillar industrial organizations. It is impossible to compare directly the level of price caps without taking into consideration the relative size of the bases to which these caps are applied (contributions and assets). As a consequence, summary synthetic measures like charge ratios and equivalent asset management fees need to be used. Figure 3 and Table 20 report the forty year charge ratios and asset management equivalent fee among select countries. Bulgaria shows one of the highest levels of administrative fees, only lower than Turkey and Czech Republic.

69. For instance, Bulgarian pension funds have a forty year charge ratio of more than 25 percent. The charge ratio looks at the long run effect of the current fee structure (i.e., unchanged in the future) on the cash balance available at retirement. It is defined as one minus the accumulation ratio, where the latter is the ratio of the final cash balance produced when fees are charged over the cash balance where fees are not charged. In Bulgaria, administrative fees will reduce final cash balances by 25 percent over a 40 year time horizon (Figure 3).

\footnotetext{
${ }^{27}$ This methodology is used by CONSAR, the Mexican pension fund supervisory authority to compare charges across funds with different fee structures.
} 
Figure 3. Forty-Year Charge Ratios in Select Countries

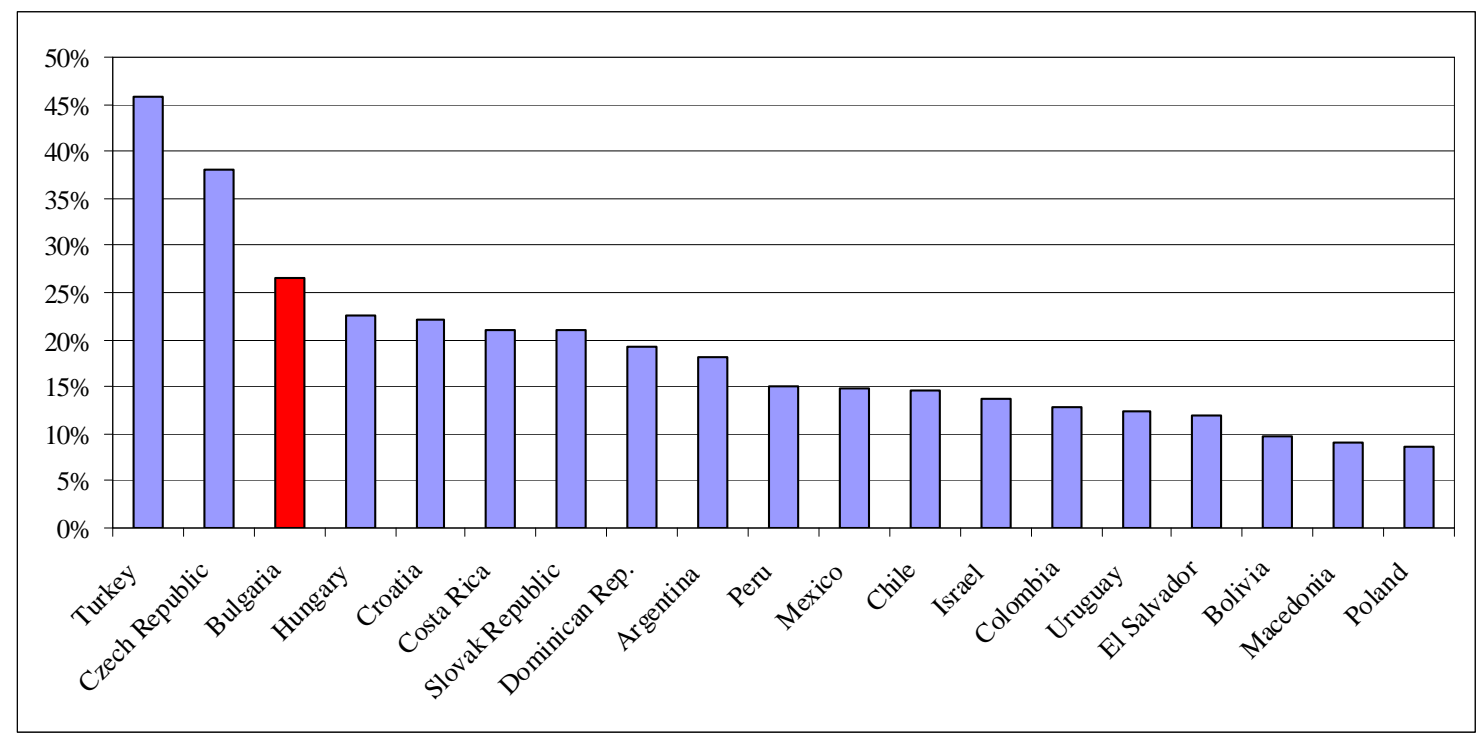

Source: OECD (2008).

Table 20. Forty-year AUM Equivalent First Floor Fees (Select Countries, Percent)

\begin{tabular}{lccccc}
\hline Country & Min & Max & $\begin{array}{c}\text { Weighted } \\
\text { Average }\end{array}$ & $\begin{array}{c}\text { Standard } \\
\text { Deviation }\end{array}$ & $\begin{array}{c}\text { Coeff. of } \\
\text { Variation }\end{array}$ \\
\hline Argentina & 0.69 & 0.83 & 0.77 & 0.05 & 6.87 \\
Bolivia & 0.39 & 0.39 & 0.39 & 0.00 & 0.27 \\
Chile & 0.56 & 0.69 & 0.61 & 0.04 & 7.29 \\
Colombia & 0.46 & 0.58 & 0.53 & 0.04 & 8.42 \\
Costa Rica & 0.69 & 0.98 & 0.92 & 0.13 & 14.01 \\
El Salvador & 0.49 & 0.49 & 0.49 & 0.00 & 0.00 \\
México & 0.46 & 0.88 & 0.62 & 0.12 & 18.96 \\
Peru & 0.54 & 0.70 & 0.63 & 0.07 & 11.62 \\
Dominican Republic & 0.64 & 0.84 & 0.84 & 0.09 & 10.80 \\
Uruguay & 0.42 & 0.65 & 0.51 & 0.11 & 20.89 \\
\hline Slovakia & 0.85 & 0.96 & $0.911 /$ & 0.05 & 5.49 \\
Poland & 0.23 & 0.26 & 0.24 & 0.01 & 4.17 \\
Hungary & 0.13 & 0.98 & $0.631 /$ & 0.25 & 39.92 \\
Turkey & 2.02 & 3.58 & 2.48 & 0.44 & 17.67 \\
Czech Republic & 0.77 & 2.84 & 1.92 & 0.55 & 28.67 \\
Bulgaria (UPF, PPF) & 1.20 & 1.02 & 1.20 & 0.00 & 0.00 \\
\hline Soure: Coveral. & $2006)$ &
\end{tabular}

Source: Corvera et al. (2006) with updated data as of June 2007.

Own calculations for Poland, Slovakia, Hungary and Bulgaria; OECD (2008) calculations for Turkey and Czech Republic. 1/: First floor fees exclude second floor fees that pension funds indirectly charge to participants by purchasing shares in mutual funds. All data is as of June 2007; standardized wage growth, real rate of return and 100 percent contribution density; 2/ Unweighted.

70. Price caps have several drawbacks: first, they discourage investment in asset management quality. This is a major issue, because annual underperformance of only 1 
percentage point over the lifecycle can reduce final cash balances by around 20 percent. When caps are binding, they simply starve the asset management function of needed income. This can contribute to low investment in asset management quality, ${ }^{28}$ high second floor fees and excessive indexing. ${ }^{29}$ Non binding price caps mislead potential reformers into believing that current fees are acceptable just because they are capped and all funds feel justified to charge the maximum allowed by the cap (as in Bulgaria). Hence, they discourage the adoption of policies that promote competition and healthy switching among pension firms and/or legitimize charges at the level of the cap irrespective of service quality. ${ }^{30}$

71. Second, they discriminate against pension funds with a less valuable customer base. This is due to the fact that caps apply to rates (typically a percentage of contributions or assets ) and not to prices per unit of service. Hence, a given cap allows less revenue per customer to pension firms with a low average base. As a consequence, and in the presence of fixed costs per customer, increasing dispersion in the average base becomes more discriminatory across firms; when the base increases for exogenous reasons a given cap becomes less restrictive; and a decrease in the cap takes away more revenue per customer in high-base firms than in other firms, affecting incentives differently across pension firms. ${ }^{31}$

72. Third, participants may not benefit from the introduction of caps after all. Caps can be easily evaded through second floor fees. This does not yield additional revenues to the pension firm but it reduces net yields for customers. In Chile, for instance, the extensive use of mutual funds for foreign investment with an average fee of 100 basis points, costs on average an extra 30 basis points on total assets to participants. The use of third party investment vehicles makes caps ineffective as a policy instrument to redistribute rents from firms to participants unless pension firms are required to negotiate fees with mutual funds as in Sweden.

\footnotetext{
${ }^{28}$ The causal relationship (rather than the mere association suggested in the text) between caps and poor asset management is obviously an empirical issue. For instance, Australian retail funds have the highest fees and the worst investment performance of all types of funds.

${ }^{29}$ Good example of these problems are the Chilean or Polish second pillars or the US TSP. In Poland, caps on fees are set at 50 basis points of assets and are scheduled to decrease to 30 basis points in the long run. As a consequence, the average pension fund has a very low investment in asset management quality: it employs only three investment officers with the most sophisticated fund hiring nine. (Yet, Polish pension funds have reported good investment returns, at least in the period 2000-05 as reported in Table 14) In Chile, foreign investments are conducted through mutual funds and the administrative fees charged by them are not captured in total fees charged by AFPs. In Sweden, this problem is resolved by the PPM negotiating a set of caps and rebates with the more than 500 funds among which individual can chose (see Palmer 2008 for a list of rebates). For the US TSP, which despite not being subject to price caps charges only between 4 and 6 basis points on assets, the result is that the only portfolios offered to participants are passive indexing portfolios with low yields. While of course, there is no evidence that active asset management is superior to purely passive asset management over the long run, it is also of course an empirical question whether hybrid investment policies (not purely active policies) yield higher average long term returns than purely passive indexing policies.

${ }^{30}$ Behavior observed in Poland, for instance.

${ }^{31}$ Think of a mean preserving spread in the population base with funds having different means.
} 
73. Fourth, they expose regulators and supervisors to potential capture and firms to high regulatory risk. The absence of a formal process to set caps that reflects adequately the actual production costs does not protect the due process right of firms. This forces pension firms to rely on lobbying and related practices to make their point of view known when caps are set. In this case, regulatory capture by well connected market players becomes a likely possibility. At the same time, pension firms are exposed to excessive regulatory risk if a populist administration decides to arbitrarily set very low caps.

74. Finally, caps need to be lowered continuously as they are applied to trending bases and simple legislative schedules do not provide strong incentives for cost cutting. Contributions and assets under management have high marginal growth rates while pension marginal costs are on average very low. This means that participants are charged over time increasingly more for the same services received unless caps are periodically revised. To avoid capture, many countries commit to an arbitrary price cap decrease schedule codified in the legislation which further increases regulatory risk. For instance, the FSC is committed to an arbitrary decreasing schedule of price caps, the timing of which is strongly opposed by the PICs association.

75. The FSC should consider agreeing with the industry on a price cap decrease schedule linked to a socially acceptable target for sharing revenues between pension firms and participants. Price controls create distortions and are considered a second best to redistribute rents in favor of participants relative to a situation where a high price elasticity of demand achieves this objective. An explicit adjustment mechanism for the two ceilings in Bulgaria linked to the cost structure of PICs could be a desirable feature: without it, and in the absence of price-sensitive participants, trends in commission bases can play havoc with pension firm revenue and can expropriate participants as in any other mandatory DC markets. In order to compensate for the realized trends in the average base for the whole system, the ceiling can be reduced automatically every quarter by the rate of increase in the base according to the following formula:

$$
\text { ceiling }_{t+1}=\text { ceiling }_{t}\left[\frac{1+p_{t}}{1+\frac{\text { base }_{t}-\text { base }_{t-1}}{\text { base }_{t-1}}}\right](1-x)
$$

76. The aforementioned formula aims at providing incentives for costs savings and price competition but it should be used only temporarily. ${ }^{32}$ The formula aims at establishing an automatic exogenous reduction in the real revenues to pension firms over time while providing incentives for cost savings and price competition. This formulation allows pension firms to keep some of the cost savings they make, but participants also benefit by an assumed cost-saving of $x$ percent per period, which is always passed on to them, even if pension firms

\footnotetext{
${ }^{32}$ The data needed for this would not be available at the end of period $t$. So the formula replaces $p_{t+1}$ with $p_{t}$ and base $_{t} /$ base $_{t+1}$ with base $_{t-1} /$ base $_{t}$. The approximation error would be zero when prices and base do not change. In any case, since deviation should have a zero mean, they should cancel out over time.
} 
lag behind in their cost-cutting efforts. The role of this exogenous reduction is to reduce the pressures due to both political interference and to lobbying. At the same time, it promotes price competition as firms which successfully reduce costs in advance can reduce prices in advance of the reduction of the cap in order to attract clients. However, exogenous cuts in revenues cannot be forced onto the industry ad infinitum. This approach will promote market consolidation and discriminate against funds without deep pockets. Hence, it should be somehow linked to the cost structure of PICs and it should be used only as a way to reaching a socially acceptable target revenue sharing between pension firms and participants while other measures are adopted to promote competition and lower barrier to entries. ${ }^{33}$

\section{Disclosure rules}

77. While used in several countries, price caps should be seen as a transitional arrangement towards improving competition and lowering barriers to entry. Given the drawbacks of price regulation, other measures aimed at increasing competition and lowering barriers to entry could be explored. These include improving disclosure rules to promote comparability of risk adjusted net rates of return, lowering barriers to entry while promoting price competition and facilitating switching towards low cost funds while controlling for possible frauds and marketing wars.

78. Disclosure rules are generally sound but could be enhanced to facilitate comparability of performance across pension funds. PICs have to inform participants annually about the performance of their individual accounts. Additionally, they need to publish their annual financial statements. The FSC, on its part, publishes on its website detailed information on fees and gross performance of pension funds. While these disclosure rules are generally sound, several actions should be considered to increase the scope for price competition and to lower barriers to entry.

79. The annual statements received by participants should include individualized performance comparison with other pension firms. At present PICs are not allowed directly to compare their performance with competitors in their marketing material. However, elasticity of demand is likely to increase if individuals receive in their homes periodic ranking of performance of their individual account from their providers. If marketing rules prohibit firms to compare performance, the FSC could develop a template to be used by each pension firm in the individual statements though which the participant is notified what would have been his/her net performance if he/she had been member of any other pension firm licensed to operate in the market.

80. In addition, the FSC should rank periodically the aggregate risk adjusted net performance of each pension fund over short, medium and long term horizons. While the one-to-one relationship between participants and providers is the most effective way to transfer financial knowledge and information, the FSC could complement individualized

\footnotetext{
${ }^{33}$ An alternative proposition could be some form of rate of return regulation with cost factors and investment objectives. However, the difficulty is to find an appropriate industry benchmark to establish target returns.
} 
comparisons to be introduced in the annual statements with aggregate rankings. These rankings should include short, medium and long term rankings, ideally at 1, 3, 5 years and since 2002. In addition, returns should be risk adjusted to promote understanding among participants about the risks entailed in the asset allocation strategies of different PICs and funds.

81. Generalized Sharp ratios appear to be superior risk adjusted measures if risk free rate or benchmarks are adequately chosen. The Sharpe ratio is calculated by subtracting the rate return of a benchmark from the rate of return of a portfolio and dividing the result by the standard deviation of such difference. The benchmark could be the risk-free rate or the benchmark for each asset class in the portfolio. Both the choice of the risk free rate and the benchmark would affect the measurement of risk adjusted performance and should be agreed upon ex ante with the industry.

82. While risk adjusted measures are agreed with the industry, simple measures of portfolio volatility should be disclosed by the FSC. As the process of agreeing on the adequate benchmark for each asset classes in which PICs can invest or on the appropriate reference maturity for the risk free rate, simple measure of volatility, or quality of portfolios, should be disclosed by the FSC. Quality portfolio measures could indicate the degree of liquidity or asset or geographical diversification and would greatly contribute to promote understanding of the investment risks embedded in each PIC investment strategy.

\section{Automatic assignation rules}

83. The automatic assignation rule in Bulgaria is not exclusively based on net performance. It is typical of many countries to assign undecided individuals who enter the labor market to pension firms. The rationale for these types of rules is that in the presence of zero elasticity of demand, a benevolent regulator needs to choose on behalf of inert individuals. The automatic assignation rule in Bulgaria is described in the FSC instruction No 1 of 2004 and it is different from that used in many other countries in various ways. First it allocates undecided participants four times a year to all pension funds in the market rather than the top percentile (in Mexico, the top quartile is used but this could be any other arbitrary percentile) of pension firms that score best on the used metrics. This does not provide sufficient incentives for pension firms to compete for undecided members through the automatic assignation rule. Second, it allocates undecided participants to funds not exclusively on the basis of fees or net returns. More specifically, it considers PICs' gross returns calculated on the previous 24 months, total fees charged and the number of new participants that have elected any one fund. The third variable is clearly not linked (directly or indirectly) to net performance and it assumes that new participants have superior knowledge about long term performance of the PIC in which they choose to participate. The literature on financial education clearly tell us that individuals are not able to rationally make complex financial decisions; in addition, since asset management is a credence good, the presumption that new participants have superior knowledge about the performance of the fund they choose is difficult to support.

84. The automatic assignation rule for undecided participants should be re-designed to

promote stronger price competition. The FSC should consider assigning undecided members 
to the top quartile of pension firms in terms of fees only or on net returns only or on net risk adjusted returns only. First, by setting the cut-off limit for automatic assignation to only the top quartile of pension firms, stronger incentives for price competition would be created than by allowing all firms to receive some undecided members, as it is currently the case. Second, whether the assignation rule should be based on net returns depends on the correlation between past and future performance. Clearly, there is a very weak link between the two but this link increases with the length of period for which past performance is calculated. It is believed that a 36 months period would be sufficient to smooth out random good performance but specific considerations should be made for new entrants with no performance history. Finally, net performance could be risk adjusted to account for the concavity of expected returns to risk.

\section{Switching among funds}

85. Currently, less than 2 percent of contributors switch pension funds every year. The turnover is much lower than the average 17 percent observed in Latin American countries (Table 21) but reportedly, similar to other countries in Eastern Europe. ${ }^{34}$

Table 21: Number of Transfers across Latin American Pension Funds, 2000 mid-2007 (thousand)

\begin{tabular}{lrrrrrrrr}
\hline \multicolumn{1}{c}{ Country } & \multicolumn{1}{c}{2000} & 2001 & \multicolumn{1}{c}{2002} & \multicolumn{1}{c}{2003} & 2004 & 2005 & 2006 & Jun-07/1 \\
\hline Argentina & 401 & 413 & 331 & 364 & 711 & 243 & 432 & 460 \\
Bolivia & -- & -- & -- & 3 & 3 & 4 & 4 & 4 \\
Chile & 256 & 235 & 229 & 275 & 212 & 235 & 235 & 270 \\
Colombia & n.a. & n.a. & 170 & 123 & 80 & 73 & 67 & 64 \\
Costa Rica & -- & 6 & -- & 75 & 74 & 97 & 99 & 140 \\
El Salvador & 135 & 78 & 41 & 53 & 37 & 68 & 10 & 5 \\
Mexico & 99 & 117 & 133 & 431 & 1,205 & 2,438 & 3,849 & 3,869 \\
Peru & 7 & 5 & 9 & 9 & 10 & 129 & 643 & 640 \\
Dominican R. /2 & -- & -- & -- & -- & 1 & 1 & 1 & 1 \\
Uruguay & n.a. & 0 & 1 & 1 & 0 & 1 & 1 & 1 \\
\hline Total transfers & 898 & 853 & 913 & 1,333 & 2,332 & 3,288 & 5,339 & 5,454 \\
Total contributors /3 & 18,618 & 20,075 & 24,070 & 25,719 & 26,885 & 28,724 & 30,490 & 31,996 \\
Turnover /4 & 4.82 & 4.25 & 3.79 & 5.18 & 8.67 & 11.45 & 17.51 & 17.04 \\
\hline
\end{tabular}

Source: Own calculations on AIOS data.

/1 period June 2006 - June 2007; /2 switches were allowed only starting with 2004; /3 country specific definition for the month preceding the reference month with the exception of Mexico where the data refers to the two months preceding the reference month; 44 Number of switches measured as percent of contributors.

86. Facilitating switches towards low cost or higher net return PICs would further promote price competition and lower barriers. Members are allowed to switch only once a year and a BGL 20 exit fee, directly withdrawn from their account, is charged by the ceding PIC to the leaving participant. The FSC plans to eliminate switching restrictions in the hope that these would increase demand elasticity.

\footnotetext{
${ }^{34}$ Actual data not available.
} 
87. The Mexican authorities have also promoted switching to low cost funds in the period 2002-07. The Mexican supervisory authority (CONSAR) introduced a series of reforms starting with 2002-03 aimed at facilitating switches to low cost funds. These included: 1) eliminating the requirement for the ceding fund to intervene in transfers; 2) reducing the transfer period from 3 months to 13 days; 3) simplifying requirement of documentation for transfers; 4) centralizing the transfer validation in a single agency (PROCESAR); 5) allowing individuals to initiate transfers over the internet; 6) improving the quality of information disclosure at the level of individual consumers and on the website of CONSAR; 7) automatically assigning undecided individuals to low fee funds; and 8) eliminating time restriction to switches when such switches occurred from higher fee to lower fee funds. These reforms contributed to lowering barriers to entry by securing a pool of accounts to low fee funds.

Figure 4. Switches in the Mexican AFORE Market (2006)

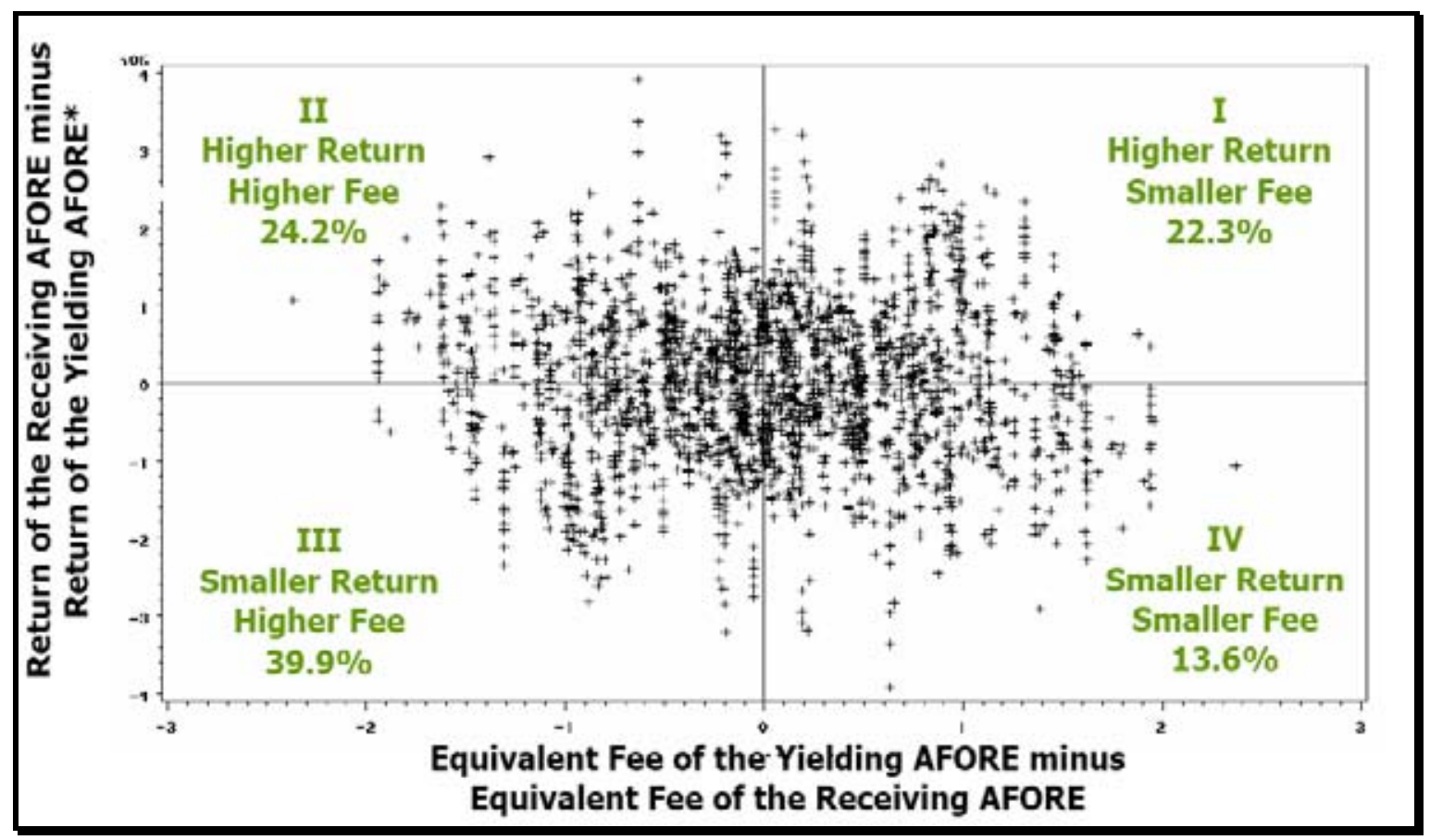

Source: Calderón et al. (2008).

88. Consequently, turnover in Mexico increased dramatically but many individuals did not switch to low cost funds. The turnover in the Mexican industry (measured as the number of switches over the number of contributors) increased from 0.5 percent to around 18 percent in the period between 2000 and 2006. In addition, pension administrators increased the amount of money spent on marketing, especially after 2003. Finally, among the almost 3.8 million switches in 2006, only 22.3 percent of switches were towards pension administrators with lower fees and higher historical rates of returns, 24.2 percent of the switches were towards administrators with higher historical rates of return and higher fees, 39.9 percent of switches were towards administrators with lower historical returns and higher fees, and 13.6 percent of switches were towards administrators with lower historical returns and lower fees (Figure 4). 
89. In 2007, the Mexican authorities reintroduced limits to switches. Four key conclusions can be drawn from the Mexican example: 1) individuals cannot make rational choices (where "rational" is the way economists would like utility maximizing agents to behave); 2) agents have the incentive to make individuals switch to high agency commission funds, rather than to high net rates of return funds; 3) an increasing number of switches (albeit still small at around 2-4 percent of total switches) was considered fraudulent; and 4) an increasing amount of revenues was used in marketing rather than increasing asset management quality. As a consequence of these conclusions, the Mexican authorities reversed their policy and re-introduced in 2007 a limit of one switch per year unless the switch occurs towards higher net return funds.

90. The FSC should facilitate switches and at the same time introduce measures to limit the occurrence of switches to lower net performance funds and fraudulent switches. In order to increase demand elasticity but at the same time avoid that individuals switch to low net performance funds, it is recommended that: 1) the period for calculating gross performance be extended to 36 months; 2) that performance be risk adjusted; 3) that no limit be introduced to switches to higher net risk adjusted performance; and 4) that the current limit of one switch per year be maintained if individuals want to move to lower risk adjusted net performance funds. In order to limit fraudulent switches it is recommended: 1 ) that the exit fee be paid directly by the individual switching fund and not through his/her individual account; 2) to review the nominal value of the fee; and 3) that the fee be paid to the ceding fund rather than to the agent marketing the switch. The fact that the fee is now paid directly by the switcher and not through his/her account should increase the signaling value of the exit fee. This would allow for a reduction of the nominal value of fee. In addition, by paying the fee to the ceding fund, the switcher would be able to receive advice from both the agent of the receiving fund and the ceding fund on the value of his/her switch. This arrangement appears a reasonable compromise between keeping the ceding fund outside the switching process (to avoid delays and obstruction) and ensuring that the agent indeed is promoting a fund with higher risk adjusted net return. ${ }^{35}$

\section{B. Issues in the Payout Phase}

91. Regulation allows PICs to offer longevity insurance without being regulated like annuity companies. Since the reform, PICs are allowed to provide annuities to retirees. Whilst the FSC would approve the mortality table and the technical rate used by PICs, this is no substitute for the sound reserving and capital requirements that are applied to annuity companies in the insurance sector.

92. Pension benefits from a UPF include longevity insurance, lump sums and survivor benefits. UPFs can provide: immediate premium nominal life annuities at the statutory

\footnotetext{
${ }^{35}$ Since there is mean reversion, one could allow for switching to lower return funds provided they are also lower fee funds. In other words, the rule could stipulate free switches either to higher net return funds or to lower fee funds. However this would amount to expecting individuals to behave tactically in their switching strategy and time market downturns. In addition, it is expected that systemic price corrections apply to all asset classes or to all funds for any given asset class and therefore affect performance symmetrically across funds.
} 
pension age of 63 and 60 years for men and women, respectively; ${ }^{36}$ a lump-sum in lieu of a life annuity if the final cash balance does not enable the retiree to purchase an annuity that is more than 20 percent of the social old age pension; a lump-sum payment of up to 50 percent of the individual account in case of disability ${ }^{37}$ causing incapacity to work; and a lump sum payment or a phased withdrawal to survivors.

93. Pension benefits from a PPF include partial longevity insurance, lump sums and survivor benefits. PPFs can provide: immediate premium nominal fixed-period annuities at the statutory pension age of 63 and 60 years for men and women, respectively; ${ }^{38}$ an early retirement pension for persons working under $1^{\text {st }}$ and $2^{\text {nd }}$ labor categories which can be taken 8 and 3 years, respectively, earlier than the statutory retirement age; a lump-sum payment of up to 50 percent of the individual account in case of disability ${ }^{39}$ causing incapacity to work; and a lump sum payment or a phased withdrawal to survivors.

94. Similar benefit rules apply to benefits in the third pillar. Benefits from personal VPFs include: personal old-age or invalidity pension; survivor pension; lump-sum payments or phased withdrawals; old age lump-sum payments or phased withdrawals to survivors. Benefits from occupational VPFs include: fixed-period old-age annuity; old age lump-sum payment or phased withdrawals; lump-sum payments or phased withdrawals to survivors.

95. The regulatory framework for the payout phase from the second pillar contains several deficiencies that need to be addressed in the coming years. The rules allowing pension funds to offer annuities were poorly designed and may ultimately lead to insolvency and/or unintended transfers across cohorts, ultimately harming contributing workers and retirees. For instance, PICs are required to maintain the individual account of each retiree and disburse the outstanding balance to survivors when the retiree dies. This prevents PICs to pool longevity risk and retirees to benefit from the mortality premium severely exposing PICs to risk of insolvency and participants to unintended transfers across cohorts.

96. The menu of retirement products is probably too restricted and unable to meet the needs of retirees with different characteristics and degrees of risk aversion. The existence of a first pillar benefit providing a replacement ratio of roughly 40 percent for full career workers allows regulators to consider a more flexible menu, including partial lump-sums subject to restrictions, phased withdrawals, and a wider range of annuities. At the same time, survivors may not be sufficiently protected in the new system, as the survivor benefit in the reduced first pillar is smaller than the one in the former system and possibly not adequate and married members are not forced to buy joint life annuities.

\footnotetext{
${ }^{36}$ For some categories of workers (army, police, et cetera) immediate pension rights are acquired after a given number of years of service, irrespective of age.

${ }^{37}$ Higher than 70.99 percent.

${ }^{38}$ For some categories of workers (army, police, et cetera) immediate pension rights are acquired after a given number of years of service, irrespective of age.

${ }^{39}$ Higher than 70.99 percent.
} 
97. Retirees face annuitization risk at retirement and afterwards longevity risk, investment risk, inflation risk, bankruptcy risk, liquidity risk and bequest risk. The main risk faced by pensioners is longevity risk, the risk that they will live longer than expected and outlive their savings. Closely related to this is investment risk (the risk of large financial losses in their investments), inflation risk (the risk that their savings will be eroded by inflation) and bankruptcy risk (the risk of failure of the institution in which their savings are invested). Pensioners may also face liquidity risk if their savings are invested in illiquid products and bequest risk if they are invested in products that do not allow for bequests in cases of death.

98. The authorities should consider a menu of retirement products that enables effective hedging of the aforementioned risks. Annuitization risk could be hedged by introducing gradual purchase requirement of deferred annuities or by skewing investment rules towards long duration bonds just before retirement. Life real annuities protect from longevity risk and inflation risk but they could be expensive if they do not share it between providers and retirees. Escalating real annuities provide full protection against inflation and also allow for a gradual increase in the real value of pensions. Their main disadvantage is that early payments are further reduced compared to fixed real or nominal annuities and are therefore even less attractive to people with short life expectancies. Variable annuities share investment and/or longevity risk between the provider and the retiree. Phased withdrawals and term annuities consist of a series of fixed or variable payments (some times linked to mortality table) whereby pensioners withdraw a fraction of their accumulated capital. They allow retirees to leave bequests but provide only marginal better protection than lump sums against the other risks. Lump sums avoid the bequest risk but are exposed to longevity, investment and bankruptcy risks.

99. The Bulgarian authorities have two main industrial organization choices for the pay out phase. The main choice for the institutional structure of the prescribed market is between a system that combines centralized administration with decentralized asset management and a decentralized system where multiple institutions compete in the provision of retirement products. The former system is found in Sweden and to a lesser extent Denmark, whilst the latter system is found in Chile, Switzerland and Australia. A less decentralized model for provision of mandatory annuitization (like the one adopted in Sweden) should be studied by the Bulgarian authorities.

100. A centralized administration through a public board would promote lower operating costs and more efficient risk pooling. Lower costs would be achieved because of scale economies and avoidance of high marketing costs. In addition, the centralized procurement of life annuities would benefit from using a larger customer base and thus more efficient risk pooling.

101. However, a centralized board is likely to be viable only in countries with the highest degree of governance. This is because centralized boards have monopsony power over service providers, their performance is difficult to evaluate and they are exposed to political interference. First, a centralized board would have monopsony power over decentralized 
asset managers which may lead them to underinvest in the adoption of innovations improving asset management quality. ${ }^{40}$ In addition, it is very difficult to monitor and evaluate the overall performance of the board due to the absence of peer benchmarks (the board is unique). Finally, procuring boards are usually public offices, in the sense that board members are designated by politicians, unions, employer associations or large employers. The risk of political interference may prompt public boards to adopt "safety-first strategies" such as: delaying the adoption of new asset management techniques (when conducted in house) until they are fully established in the mainstream practice; ${ }^{41}$ discharging responsibility for monitoring asset management on participants; ${ }^{42}$ or leaving quality control of asset management services to external parties. ${ }^{43}$ For these reasons, a centralized board should only be adopted in countries with the highest levels of governance, transparency and public accountability.

102. A decentralized industrial organization would promote greater competition and would stimulate innovation. Greater competition would be enhanced as new annuity providers can freely displace incumbents by improving asset management and annuity product innovations.

103. However, it would suffer from high marketing costs and be impractical if retirement products are very standardized. It would suffer from market consolidation and the growing prevalence of a small number of providers, which would result from the significant scale economies that characterize retail financial markets, and the related tendency to incur large marketing costs, mostly taking the form of high commissions paid to agents and brokers. ${ }^{44}$ The case for a decentralized competitive structure is significantly weakened when strict restrictions are applied on annuity products and their pricing. It is also weakened when insurance companies use common life tables, in which case competition is effectively limited to asset management and marketing campaigns.

104. For the third pillar, a draft amendment to the SIC is being considered, which includes payout phase regulation development in the VPFs. This amendment includes improvement of pension products, introduction of special technical reserves and increasing capital requirements. Upon payment of lifelong pensions the pension insurance company should form technical provisions in the voluntary pension fund, which should be fully funded. When

\footnotetext{
${ }^{40}$ Innovation of financial management techniques is an expensive sunk investment for asset managers.

${ }^{41}$ The most extreme form of this kind of herd behavior is to fully index all portfolios offered to participants. Indexing implies low commissions and the value added of alternative investment strategies (not necessarily purely active) is a matter of empirical evidence.

${ }^{42}$ This is the case of the PPM in Sweden which involves over 70 management companies operating over 700 investment funds.

${ }^{43}$ This strategy is more likely to be adopted when the return performance is evaluated by the public procurement board itself.

${ }^{44}$ This is why jurisdictions like Chile adopted a system of blind quotations (SCOMP) to reduce price distortions in the marketing of annuities.
} 
the insured person reaches retirement age and chooses a lifelong pension, the amount of his/her individual account should be transferred to the technical reserve where the longevity risk can be pooled. The technical provisions should have separate accounting and special investment requirements.

\section{Policy Conclusions}

\section{A. The Market}

105. The Bulgarian pension system follows a three pillar design, typical of other countries in the region. The first pillar provides a basic earnings-related pension and is managed by the National Social Security Institute. The second and third pillars are composed respectively of mandatory and voluntary defined contribution (DC) plans managed by pension firms known as pension insurance companies (PICs).

106. The Bulgarian second and third pillars are small, highly concentrated but growing rapidly. Coverage of the second and third pillars is 81 percent and 15 percent of the labor force, respectively. Accumulated net assets amount to 3 percent and 1 percent of GDP for the second and third pillars, respectively. The size of the third pillar is surprisingly high. This is due to the longer history of voluntary funds and to the membership restriction applied to mandatory funds.

107. The asset allocation of Bulgarian PICs is likely to be inefficient but broadly similar to that observed in other countries that recently reformed their pension system. PICs have a high share of their assets in bank deposits (20 percent) and a low share in mortgage bonds (3-4 percent). The high share in bank deposits is not considered a source of risk due to the limited participation of banks, or financial sector groups, in PICs' paid up capital. It is believed that this is an indication of low risk management capacity and that the current allocation is not efficient. The risk management culture at pension funds is in its early stages and pension companies are trying to recruit risk management experts. Finally, the equity allocation is rapidly increasing at the expense of government debt; so is diversification in the euro zone. However, even with the recent higher equity exposure, Bulgarian PICs still play a relatively small role in the local capital market, especially in price discovery on the BSE.

108. Nominal performance has been higher than in other countries in the region but performance net of fees is lower than the performance of the first pillar. Nominal performance of PICs in the period 2002-07 averaged 11 percent but it has been rapidly decreasing on a risk adjusted basis; this is consistent with the recent shift towards equities. However, fees charged by pension funds averaged 2.7 percent of assets under management over the same period resulting in net annualized yield lower than the average wage growth of 11 percent. Wage growth is a measure of the implicit return in a balanced PAYG system and a common benchmark for assessing the performance of a second pillar.

109. Market concentration and low demand elasticity have yieded in Bulgaria price distortions comparable to other countries with similar industrial organizations. Market power of PICs has been increasing in spite of modestly decreasing market concentration. On average, operational profits derived from charges to participants amount to 12 percent of total 
fees in 2007 while these increase to 23 percent if income from own funds is included in the calculations. These margins are lower than what is observed in more mature mandatory DC markets due to the fact that PICs have not yet reached an efficient scale of production. Market concentration, power and profitability are expected to increase with time if price caps are not reduced.

\section{B. Regulation and Supervision}

110. The supervisory capacity and the regulatory framework are generally sound; however, the following select aspects could be strengthened.

\section{Issues related to the accumulation phase}

111. Licensing criteria and procedures in Bulgaria are generally sound but monitoring of transactions with related parties could be strengthened. For instance, existing restrictions on ownership of PICs are reportedly circumvented by the complex structure of Bulgarian and foreign groups. This may facilitate transactions with related parties and coordinated investing of these funds in illiquid shares on the BSE. This could result in price manipulation and raises consumers' protection concerns. The FSC could tighten the definition of related parties and develop a map of indirect ownership structure of pension funds.

112. Governance and risk management rules are also generally sound but could be strengthened. For instance, the rules on powers and responsibilities of directors ensure that PICs are on average managed by reputable and qualified individuals. In particular, directors are held personally responsible for mismanagement of the funds but are not required to obtain personal liability. However, the absence of fit and proper test for PICs' owners raises concerns about reputation of few non-financial sector shareholders. Additionally, while allowed to invest in derivatives, PICs are not required to be certified to invest in derivatives. The FSC could introduce fit and proper test and related changes in control rules for owners. Additionally, it could consider requiring directors to obtain liability insurance and relevant officers to be certified in the use of derivatives.

113. Investment rules are fairly liberal and provide ample scope for geographical diversification in the Euro zone. However, they severely limit equity exposure, they do not permit investments in infrastructure, they may create incentives for regulatory arbitrage in certain asset classes like structured products, lack important prudential criteria for monitoring risks taken by investment managers in the use of derivatives and do not allow for investment choices by participants to mandatory funds. A review of the investment rules is justified by the plans to introduce life cycle funds as default investment options for participants in the future. Such a review would aim at promoting investment in riskier, illiquid assets like equities, mortgage bonds, infrastructure bonds, directly or indirectly via mutual funds.

114. The minimum return guarantee has not generated herding, as commonly assumed, but its specific designs penalize conservative investors and facilitate manipulation of the benchmark. Actual portfolio allocation and performance is sufficiently heterogeneous across PICs to discount any concern related to herding. In addition, PICs tend to buy and hold investments, limiting their role in price discovery in many asset classes. However, the 
minimum return benchmark is calculated on a short period of 24 months and it is not risk adjusted. This penalizes conservative investors and it facilitates benchmark manipulation through coordinated investments of PICs indirectly controlled by the same group of shareholders. An effective way to neutralize vulnerability to price pressures is to extend the benchmark to 3 or 5 years and adjusting it for risk.

115. Price controls may have been successful at redistributing rents to participants but additional efforts should be made to promote price competition. Like many countries in the region Bulgaria adopted price controls as a means to limit the market power of pension firms. For the specific case of Bulgarian UPFs and PPFs, the charges on the flow are capped to 5 percent of contributions and on the stock to 1 percent of asset under management. For VPFs caps are 7 percent of contributions and 10 percent of investment income. These caps may have been successful at redistributing rents to participants. However, all PICs charge the maximum allowed under the tariff scheme for UPFs and PPFs suggesting that insufficient incentives for price competition exist for pension firms in the second pillar.

116. Efforts to promote price competition would include enhancing disclosure rules. Disclosure rules are generally sound but could be enhanced to facilitate comparability of performance across pension funds so as to promote price competition and lower barriers to entry. PICs have to inform participants annually about the performance of their individual accounts. Additionally, they need to publish their annual financial statements. The FSC, on its part, publishes on its website detailed information on fees and gross performance of pension funds. However, PICs are not allowed to directly compare their performance with competitors in their marketing material. While these disclosure rules are generally sound, several actions should be considered to increase the scope for price competition and lower barriers to entry: the FSC could develop a template through which participants are notified in their annual statements of their net performance if their had been member of any other pension firm licensed to operate in the market; and in addition, the FSC could produce and publish periodic aggregate rankings on the basis of risk adjusted net rates of return for 1,3, 5 years and since the enactment of the SIC. Finally, while the FSC collect income data for PICs by type of funds managed, data on operational costs are not disaggregated by type of funds. Such a disaggregation would allow to explain why fees charged to voluntary funds are much lower than fees charged to mandatory funds and why their performance is higher.

117. Additionally, they would include reviewing the automatic allocation rules for undecided participants. As in many other countries, undecided members are assigned to funds according to a regulated algorithm. However, one of the criteria used in Bulgaria is election by new participants which is not related to fees or gross performance. The automatic assignation rule should be based only on net performance (ideally risk adjusted) and calculated over a longer period of at least 36 months in order filter out spurious performance results. Finally, allocation of undecided individuals should be limited to the top quartile of funds, rather than extended to all funds as it is current the case. The combination of these two recommendations is expected to improve the scope for price competition, both in terms of fees and gross performance.

118. Finally, they would include promoting switches to higher net return funds while discouraging marketing wars and fraudulent switches. Policies facilitating switches have 
resulted in other countries in excessive churning rates, marketing wars and fraudulent switches. The FSC should continue to facilitate switches and at the same time introduce measures to limit the occurrence of switches to lower net performance funds and fraudulent switches. In order to increase demand elasticity but at the same time avoid that individuals switch to low net performance funds, it is recommended that: the period for calculating gross performance be extended to 36 months; that performance be risk adjusted; that no limit be introduced to switches to higher net risk adjusted performance; and that the current limit of one switch per year be maintained only if individuals want to switch to lower risk adjusted net performance funds. In order to limit fraudulent switches it is recommended: that this fee be paid directly by the individual switching fund and not through his/her individual account; and that the fee be paid to the ceding fund rather than to the agent marketing the switch.

\section{Issues related to the pay out phase.}

119. The regulatory framework for the pay out phase needs overhauling with important policy choices to be made in terms of retirement products and industrial organization. The rules allowing pension funds to offer annuities were poorly designed and may ultimately lead to insolvency and/or unintended transfers across cohorts, ultimately harming contributing workers and retirees. In addition, the menu of retirement products is probably too restricted and it is unable to meet the needs of retirees with different characteristics and degrees of risk aversion. The FSC should carefully study the menu of retirement product that adequately meets the needs of retirees; and the advantages of disadvantages of alternative industrial organization models for the provision of mandatory longevity insurance in the second pillar. A menu of products that entails increasing risk sharing between providers and retirees of key risks would be desirable. Alternative industrial organization models include centralized versus decentralized provision of insurance. A centralized administration through a public board like in Sweden would promote lower operating costs and more efficient risk pooling. However, monitoring performance would be problematic due to the lack of benchmarks and the risk of undue political influence would require the highest degree of public governance, transparency and accountability. A decentralized industrial organization like in Chile would promote greater competition and would stimulate innovation. However, it would suffer from high marketing costs, require sophisticated marketing regulation and be impractical if retirement products are very standardized.

120. For the third pillar, a draft amendment to the SIC is being considered, which includes payout phase regulation development for VPFs. This amendment includes improvement of pension products, introduction of special technical reserves and increasing capital requirements. When the insured person reaches retirement age and chooses a lifelong pension, the amount of his/her individual account should be transferred to the technical reserve where the longevity risk can be pooled. These provisions may create the wrong precedent for the UPFs where it would be critical to avoid unintended intergenerational transfers across cohorts between the accumulation accounts and the payout phase accounts. In addition, they may unintentionally create regulatory arbitrage between the insurance and the PICs' markets in the area of annuities. These concerns would be greatly reduced if annuity provision from the third pillar would be left to general life insurance companies. 


\section{REFERENCES}

AON, 2007, European Pension Barometer: Measuring the pressure on EU pensions systems, AON Consulting Ltd., (UK).

Arvai, Zsofia, 2007, The Bulgarian Capital Market, Mimeo.

Calderón-Colín, Roberto, Enrique E. Domínguez, and Moisés J. Schwartz, 2008, Consumer Confusion: The Choice of AFORE in Mexico. IMF Working Paper No. 08/117 (Washington: International Monetary Fund).

Corvera, F. Javier, J. Mateo Lartigue, and David Madero, 2006, Comparative Analysis of Administrative Fees of Pension Funds in Latin American Countries, Mimeo.

FSC, 2007, Overview of the Bulgarian Pension System, www.fsc.bg.

Ivanova, A., 2007, Adequacy and Expected Replacement Ratio of Mandatory Pension Funds in Bulgaria, Presentation made by FSC at workshop on Private Pensions-Tallin, September 6.

Impavido, Gregorio, and Roberto Rocha, 2006, Competition and Performance in the Hungarian Second Pillar, World Bank Policy Research Working Paper No.3876.

OECD, 2007, Pension Markets in Focus, November 2007, Issue 4. , 2008, Comparison of Costs and Fees in Countries with Private DC systems, Mimeo.

Palmer, Edward, 2008, The Market for Retirement Products in Sweden, Mimeo.

Raddatz, Claudio and Sergio Schmukler (2008), Pension Funds and Capital Market Development: How Much bang for the Buck? The World Bank, mimeo.

Valdés-Prieto, Salvador, and Iván Marínovic, 2005, Contabilidad Regulatoria: Las AFP Chilenas, 1993-2003, Documentos de Trabajo 279, Instituto de Economía, Pontificia Universidad Católica de Chile. 


\section{Appendix I. Overview of Second and Third Pillars Institutional Arrangements}

121. Bulgaria has adopted the World Bank 3-pillar model. Supplementary pension insurance is implemented by participation in mandatory universal and/or professional pension funds, supplementary voluntary pension funds and/or supplementary voluntary pension funds with occupational schemes, which are established and managed by pension insurance companies (PICs) licensed by Financial Supervision Commission (FSC).

\section{Mandatory Second Pillar}

122. There are two types of mandatory pension funds in Bulgaria, universal and professional. Public and private-sector employees and self-employed persons born in 1960 or later must become members of a universal pension fund. Each employee, working under specific conditions (labor categories I and II- under heavy and hazardous conditions) must, regardless of their age, become a member of a professional pension fund in addition to the universal pension fund. Professional pension funds are not organized by the employer and individuals may join the fund of their choice. Both the universal and professional pension funds are independent legal entities created and managed by a licensed joint-stock company, called a pension insurance company (PIC).

123. Each PIC may establish and manage only one universal and one professional pension fund. The PIC must obtain a license from the FSC and have a minimum required capital. For each fund must also be granted an authorization by the Deputy Chairperson of the FSC. The fund is represented by the PIC, which also manages the benefit payment.

124. The contribution to the mandatory private pension schemes is a part of the total social security contribution collected by the National Revenue Agency which transfers the parts of the contributions to the respective funds. Members or employers cannot make contributions above the legally defined levels.

125. The contribution for mandatory pension funds is a percentage of the monthly insurance income. This percentage is determined in advance by the law. The basis for the contribution calculation cannot be under the minimum insurance income and cannot exceed the maximum monthly amount of the insurance income. The contribution for the universal fund is divided between the employer and the insured person, except in the case of the selfemployed persons who pay the whole amount. The contributions for the professional pension funds are entirely paid by the employers

\section{Voluntary Third Pillar}

126. Supplementary voluntary pension insurance is implemented in supplementary voluntary pension funds and in supplementary voluntary pension funds with occupational schemes.

127. Pension insurance in the supplementary voluntary pension funds is carried out on a fully-funded principle on the basis of defined contributions. Every natural person, who has reached the age of 16, may voluntarily insure himself or herself or be insured in 
supplementary voluntary pension funds. Supplementary voluntary pension insurance is personal. Each person insured at a supplementary voluntary pension fund and at a supplementary voluntary pension fund with occupational schemes has an individual account. The participation in a supplementary voluntary pension fund starts from the moment of the conclusion of a pension insurance contract.

128. Supplementary voluntary pension funds with occupational schemes-Every natural person, who has reached the age of 16, may be insured in a supplementary voluntary pension fund with occupational schemes. The coverage of the insured persons in these funds is stipulated in a collective bargaining agreement or in a collective contract between the sponsoring undertaking and the persons.

129. The main consideration to adopt this type of insurance into the national legislation is the necessity to transpose the EC Directive 2003/41 (IORP Directive). EC Directive 2003/41 was transposed in its entirety into the national legislation in 2006, and entered into force on 1 January 2007. As of 31 December 2007, 2 authorizations for supplementary voluntary pension funds with occupational schemes have been granted, but these funds have not started managing occupational schemes yet.

130. The Supplementary mandatory pension insurance (Universal and Professional pension funds) and the Supplementary voluntary pension insurance (Supplementary voluntary pension funds and Supplementary voluntary pension funds with occupational schemes) are regulated by Part two of the Bulgarian Social Insurance Code and by several ordinances of the FSC http://www.fsc.bg/E_fsc_page.asp?v=8. 
Appendix II. Detailed Data by Legal Entity

Table 22. Membership by Legal Entity

\begin{tabular}{|c|c|c|c|c|c|}
\hline & 2003 & 2004 & 2005 & 2006 & 2007 \\
\hline Doverie & 968,815 & $1,061,619$ & $1,129,695$ & $1,201,173$ & $1,236,578$ \\
\hline UPF & 759,665 & 843,950 & 903,847 & 967,043 & $1,000,002$ \\
\hline PPF & 69,899 & 71,721 & 72,426 & 74,628 & 74,531 \\
\hline VPF & 139,251 & 145,948 & 153,422 & 159,502 & 162,045 \\
\hline Saglasie & 260,150 & 296,500 & 334,861 & 363,608 & 404,851 \\
\hline UPF & 196,255 & 234,143 & 270,395 & 296,690 & 334,145 \\
\hline PPF & 30,684 & 30,276 & 31,780 & 33,707 & 35,490 \\
\hline VPF & 33,211 & 32,081 & 32,686 & 33,211 & 35,216 \\
\hline DSK-Rodina & 121,716 & 179,256 & 206,922 & 236,010 & 293,376 \\
\hline UPF & 92,744 & 146,776 & 173,841 & 197,259 & 244,479 \\
\hline PPF & 6,564 & 7,690 & 9,136 & 11,120 & 15,001 \\
\hline VPF & 22,408 & 24,790 & 23,945 & 27,631 & 33,896 \\
\hline Allianz Bulgaria & 611,854 & 695,774 & 752,409 & 793,918 & 820,016 \\
\hline UPF & 321,481 & 402,126 & 454,054 & 493,769 & 516,393 \\
\hline PPF & 36,494 & 37,512 & 37,263 & 37,211 & 36,439 \\
\hline VPF & 253,879 & 256,136 & 261,092 & 262,938 & 267,184 \\
\hline ING & 167,421 & 225,257 & 247,361 & 265,450 & 284,564 \\
\hline UPF & 141,699 & 190,289 & 210,131 & 225,789 & 240,463 \\
\hline PPF & 6,113 & 9,971 & 10,599 & 11,815 & 13,512 \\
\hline VPF & 19,609 & 24,997 & 26,631 & 27,846 & 30,589 \\
\hline CCB-Sila & 72,645 & 110,363 & 125,223 & 141,172 & 161,651 \\
\hline UPF & 49,801 & 86,380 & 100,029 & 113,928 & 130,592 \\
\hline PPF & 6,296 & 6,961 & 7,738 & 8,702 & 10,594 \\
\hline VPF & 16,548 & 17,022 & 17,456 & 18,542 & 20,465 \\
\hline Lukoil Garant Bulgaria & 92,266 & 117,629 & 127,683 & 139,981 & 150,702 \\
\hline UPF & 52,230 & 75,567 & 85,997 & 96,333 & 104,946 \\
\hline PPF & 8,893 & 10,537 & 10,923 & 12,161 & 13,186 \\
\hline VPF & 31,143 & 31,525 & 30,763 & 31,487 & 32,570 \\
\hline DZI (Budeshte after 1/1/07) & 99 & 29,969 & 47,685 & 60,014 & 71,164 \\
\hline UPF & $\ldots$ & 25,545 & 41,218 & 51,890 & 61,258 \\
\hline PPF & $\ldots$ & 1,507 & 2,611 & 3,499 & 4,541 \\
\hline VPF & 99 & 2,917 & 3,856 & 4,625 & 5,365 \\
\hline Toplina & $\ldots$ & $\ldots$ & $\ldots$ & $\ldots$ & 17,912 \\
\hline UPF & $\ldots$ & $\ldots$ & $\ldots$ & $\ldots$ & 8,374 \\
\hline PPF & $\ldots$ & $\ldots$ & $\ldots$ & $\ldots$ & 4,063 \\
\hline VPF & $\ldots$ & $\ldots$ & $\ldots$ & $\ldots$ & 5,475 \\
\hline Total PIC & $2,294,966$ & $2,716,367$ & $2,971,839$ & $3,201,326$ & $3,440,814$ \\
\hline Total UPF & $1,613,875$ & $2,004,776$ & $2,239,512$ & $2,442,701$ & $2,640,652$ \\
\hline Total PPF & 164,943 & 176,175 & 182,476 & 192,843 & 207,357 \\
\hline Total VPF & 516,148 & 535,416 & 549,851 & 565,782 & 592,805 \\
\hline
\end{tabular}


Table 23. Net Assets by Legal Entity

\begin{tabular}{|c|c|c|c|c|c|}
\hline (BGL 000) & 2003 & 2004 & 2005 & 2006 & 2007 \\
\hline Doverie & 162,039 & 261,300 & 363,500 & 497,351 & 735,853 \\
\hline UPF & 50,457 & 111,310 & 180,645 & 280,970 & 467,975 \\
\hline PPF & 61,328 & 85,637 & 105,460 & 127,871 & 158,390 \\
\hline VPF & 50,254 & 64,353 & 77,395 & 88,510 & 109,488 \\
\hline Saglasie & 50,804 & 76,496 & 109,369 & 162,487 & 253,000 \\
\hline UPF & 14,287 & 30,428 & 51,051 & 86,078 & 150,035 \\
\hline PPF & 26,518 & 34,145 & 44,541 & 59,364 & 76,828 \\
\hline VPF & 9,999 & 11,923 & 13,777 & 17,045 & 26,137 \\
\hline DSK-Rodina & 25,707 & 41,319 & 63,527 & 95,313 & 178,162 \\
\hline UPF & 6,073 & 16,781 & 30,644 & 52,037 & 100,462 \\
\hline PPF & 4,227 & 6,241 & 8,935 & 12,186 & 19,387 \\
\hline VPF & 15,407 & 18,297 & 23,948 & 31,090 & 58,313 \\
\hline Allianz Bulgaria & 196,643 & 279,642 & 386,533 & 491,969 & 705,279 \\
\hline UPF & 25,598 & 59,051 & 101,146 & 157,486 & 269,217 \\
\hline PPF & 36,823 & 49,913 & 60,449 & 70,173 & 86,636 \\
\hline VPF & 134,222 & 170,678 & 224,938 & 264,310 & 349,426 \\
\hline ING & 32,119 & 60,014 & 90,388 & 130,091 & 210,102 \\
\hline UPF & 10,718 & 25,018 & 42,357 & 69,205 & 120,767 \\
\hline PPF & 3,545 & 7,710 & 11,134 & 14,968 & 21,213 \\
\hline VPF & 17,856 & 27,286 & 36,897 & 45,918 & 68,122 \\
\hline CCB-Sila & 9,935 & 16,190 & 24,525 & 40,360 & 70,722 \\
\hline UPF & 2,924 & 7,870 & 14,271 & 26,117 & 47,979 \\
\hline PPF & 3,280 & 3,633 & 4,637 & 6,647 & 10,264 \\
\hline VPF & 3,731 & 4,687 & 5,617 & 7,596 & 12,479 \\
\hline Lukoil Garant Bulgaria & 33,254 & 49,497 & 65,263 & 83,921 & 125,612 \\
\hline UPF & 4,001 & 9,141 & 16,153 & 26,822 & 50,808 \\
\hline PPF & 8,096 & 13,054 & 16,946 & 21,091 & 29,305 \\
\hline VPF & 21,157 & 27,302 & 32,164 & 36,008 & 45,499 \\
\hline DZI (Budeshte after 1/1/07) & 43 & 2,956 & 9,017 & 15,920 & 30,072 \\
\hline UPF & $\cdots$ & 1,526 & 4,577 & 9,183 & 18,430 \\
\hline PPF & $\ldots$ & 499 & 1,210 & 1,992 & 3,235 \\
\hline VPF & 43 & 931 & 3,230 & 4,745 & 8,407 \\
\hline Toplina & $\ldots$ & $\ldots$ & $\ldots$ & $\ldots$ & 9,577 \\
\hline UPF & $\cdots$ & $\ldots$ & $\cdots$ & $\ldots$ & 2,689 \\
\hline PPF & $\ldots$ & $\cdots$ & $\ldots$ & $\ldots$ & 6,138 \\
\hline VPF & $\ldots$ & $\ldots$ & $\ldots$ & $\ldots$ & 750 \\
\hline Total PIC & 510,544 & 787,414 & $1,112,122$ & $1,517,412$ & $2,318,379$ \\
\hline Total UPF & 114,058 & 261,125 & 440,844 & 707,898 & $1,228,362$ \\
\hline Total PPF & 143,817 & 200,832 & 253,312 & 314,292 & 411,396 \\
\hline Total VPF & 252,669 & 325,457 & 417,966 & 495,222 & 678,621 \\
\hline
\end{tabular}


Table 24. Annual Contributions by Legal Entity

\begin{tabular}{|c|c|c|c|c|c|}
\hline (BGL 000) & 2003 & 2004 & 2005 & 2006 & 2007 \\
\hline Doverie & 63,737 & 85,322 & 97,528 & 125,058 & 194,398 \\
\hline UPF & 32,624 & 55,947 & 66,412 & 92,124 & 155,941 \\
\hline PPF & 20,092 & 19,308 & 18,508 & 20,221 & 23,689 \\
\hline VPF & 11,021 & 10,067 & 12,608 & 12,713 & 14,768 \\
\hline Saglasie & 19,818 & 27,130 & 31,477 & 41,105 & 68,192 \\
\hline UPF & 8,468 & 15,756 & 19,505 & 27,745 & 49,344 \\
\hline PPF & 8,299 & 8,673 & 8,549 & 9,375 & 11,300 \\
\hline VPF & 3,051 & 2,701 & 3,423 & 3,985 & 7,548 \\
\hline DSK-Rodina & 10,661 & 14,210 & 21,009 & 31,868 & 65,695 \\
\hline UPF & 3,794 & 8,727 & 11,969 & 17,843 & 34,092 \\
\hline PPF & 1,199 & 1,433 & 1,623 & 2,120 & 3,571 \\
\hline VPF & 5,668 & 4,050 & 7,417 & 11,905 & 28,031 \\
\hline Allianz Bulgaria & 59,243 & 79,096 & 101,919 & 115,230 & 172,708 \\
\hline UPF & 15,618 & 29,949 & 37,774 & 53,497 & 89,467 \\
\hline PPF & 10,933 & 12,566 & 11,480 & 11,609 & 12,853 \\
\hline VPF & 32,692 & 36,581 & 52,665 & 50,125 & 70,388 \\
\hline ING & 15,293 & 23,721 & 28,907 & 40,957 & 63,565 \\
\hline UPF & 6,484 & 12,996 & 16,040 & 23,342 & 39,706 \\
\hline PPF & 1,040 & 1,662 & 2,298 & 2,895 & 3,782 \\
\hline VPF & 7,769 & 9,063 & 10,569 & 14,720 & 20,077 \\
\hline CCB-Sila & 3,809 & 6,601 & 8,184 & 11,915 & 22,361 \\
\hline UPF & 1,824 & 4,543 & 5,938 & 8,940 & 16,777 \\
\hline PPF & 929 & 1,039 & 1,002 & 1,349 & 2,087 \\
\hline VPF & 1,056 & 1,019 & 1,244 & 1,626 & 3,497 \\
\hline Lukoil Garant Bulgaria & 11,053 & 13,776 & 14,669 & 18,710 & 27,889 \\
\hline UPF & 2,396 & 4,858 & 6,058 & 9,505 & 16,726 \\
\hline PPF & 2,529 & 2,742 & 3,093 & 3,877 & 4,970 \\
\hline VPF & 6,128 & 6,176 & 5,517 & 5,328 & 6,193 \\
\hline DZI (Budeshte after 1/1/07) & 109 & 1,618 & 4,523 & 7,446 & 11,969 \\
\hline UPF & $\ldots$ & 987 & 2,148 & 3,835 & 7,620 \\
\hline PPF & $\ldots$ & 166 & 389 & 675 & 1,094 \\
\hline VPF & 109 & 465 & 1,985 & 2,935 & 3,255 \\
\hline Toplina & $\ldots$ & $\ldots$ & $\ldots$ & $\ldots$ & 2,511 \\
\hline UPF & $\ldots$ & $\ldots$ & $\ldots$ & $\ldots$ & 887 \\
\hline PPF & $\ldots$ & $\ldots$ & $\ldots$ & $\ldots$ & 798 \\
\hline VPF & $\ldots$ & $\ldots$ & $\ldots$ & $\ldots$ & 825 \\
\hline Total PIC & 183,723 & 251,474 & 308,216 & 392,289 & 629,288 \\
\hline Total UPF & 71,208 & 133,763 & 165,844 & 236,831 & 410,560 \\
\hline Total PPF & 45,021 & 47,589 & 46,942 & 52,121 & 64,144 \\
\hline Total VPF & 67,494 & 70,122 & 95,428 & 103,337 & 154,582 \\
\hline
\end{tabular}


Table 25. Annual Gross Investment Performance by Legal Entity

\begin{tabular}{|c|c|c|c|c|c|c|c|}
\hline Percent & 2002 & 2003 & 2004 & 2005 & 2006 & 2007 & $\begin{array}{c}\text { Period } \\
\text { Annualized }\end{array}$ \\
\hline \multicolumn{8}{|l|}{ Doverie } \\
\hline UPF & 12.77 & 10.28 & 13.69 & 7.15 & 6.27 & 13.51 & 10.57 \\
\hline PPF & 11.58 & 10.90 & 14.21 & 8.68 & 7.43 & 13.60 & 11.04 \\
\hline VPF & $\ldots$ & 13.16 & 14.36 & 7.89 & 7.80 & 15.07 & 9.59 \\
\hline \multicolumn{8}{|l|}{ Saglasie } \\
\hline UPF & 8.80 & 14.10 & 9.97 & 8.18 & 15.10 & 15.33 & 11.87 \\
\hline PPF & 9.69 & 12.86 & 8.87 & 8.41 & 16.64 & 17.26 & 12.23 \\
\hline VPF & $\ldots$ & 10.28 & 9.23 & 8.42 & 15.62 & 17.33 & 10.00 \\
\hline \multicolumn{8}{|l|}{ DSK -Rodina } \\
\hline UPF & 8.72 & 8.91 & 9.79 & 6.78 & 7.20 & 17.67 & 9.79 \\
\hline PPF & 11.05 & 10.48 & 10.28 & 6.51 & 8.78 & 17.52 & 10.72 \\
\hline VPF & $\ldots$ & 10.56 & 9.44 & 7.04 & 9.92 & 17.82 & 9.00 \\
\hline \multicolumn{8}{|l|}{ Allianz Bulgaria } \\
\hline UPF & 6.64 & 10.44 & 10.64 & 7.63 & 3.73 & 15.73 & 9.07 \\
\hline PPF & 9.83 & 10.09 & 10.30 & 7.67 & 4.20 & 15.12 & 9.49 \\
\hline VPF & $\ldots$ & 11.14 & 10.38 & 9.70 & 5.14 & 15.43 & 8.52 \\
\hline \multicolumn{8}{|l|}{ ING } \\
\hline UPF & 12.09 & 12.54 & 10.12 & 8.20 & 7.20 & 16.02 & 10.99 \\
\hline PPF & 11.95 & 11.50 & 10.54 & 7.95 & 7.69 & 16.82 & 11.03 \\
\hline VPF & $\ldots$ & 11.17 & 9.97 & 8.67 & 9.37 & 16.77 & 9.21 \\
\hline \multicolumn{8}{|l|}{ CCB-Sila } \\
\hline UPF & 10.51 & 10.94 & 11.37 & 6.87 & 18.94 & 13.25 & 11.92 \\
\hline PPF & 10.66 & 11.46 & 11.76 & 6.46 & 17.01 & 14.02 & 11.85 \\
\hline VPF & $\ldots$ & 10.08 & 10.41 & 7.12 & 16.51 & 24.23 & 11.14 \\
\hline \multicolumn{8}{|l|}{ Lukoil Garant Bulgaria } \\
\hline UPF & 13.18 & 11.42 & 11.50 & 10.34 & 4.42 & 24.91 & 12.47 \\
\hline PPF & 12.09 & 9.73 & 11.51 & 10.04 & 3.23 & 20.77 & 11.11 \\
\hline VPF & $\ldots$ & 11.26 & 9.72 & 8.90 & 4.69 & 20.80 & 9.05 \\
\hline \multicolumn{8}{|l|}{ DZI (Budeshte after 1/1/07) } \\
\hline UPF & $\cdots$ & $\cdots$ & 10.46 & 10.13 & 7.40 & 21.14 & 7.95 \\
\hline PPF & $\ldots$ & $\ldots$ & 12.80 & 7.92 & 9.69 & 21.23 & 8.36 \\
\hline VPF & $\ldots$ & $\ldots$ & 9.48 & 11.04 & 7.61 & 34.72 & 9.90 \\
\hline Average UPF & 10.39 & 11.23 & 10.94 & 8.16 & 8.78 & 17.19 & 11.08 \\
\hline Average PPF & 10.98 & 11.00 & 11.28 & 7.96 & 9.33 & 17.04 & 11.23 \\
\hline Average VPF & - & 11.09 & 10.37 & 8.60 & 9.58 & 20.27 & 9.83 \\
\hline SD UPF & 2.44 & 1.68 & 1.27 & 1.39 & 5.36 & 3.99 & $\ldots$ \\
\hline SD PPF & 0.97 & 1.05 & 1.67 & 1.16 & 5.11 & 2.84 & $\ldots$ \\
\hline SD VPF & & 1.02 & 1.67 & 1.33 & 4.40 & 6.57 & ... \\
\hline Weighted Average UPF & 10.58 & 10.99 & 9.29 & 7.59 & 7.35 & 15.38 & 10.17 \\
\hline Weighted Average PPF & 10.78 & 11.01 & 9.67 & 8.33 & 8.45 & 15.57 & 10.61 \\
\hline Weighted Average VPF & $\ldots$ & & & 9.00 & 6.83 & 16.55 & 5.22 \\
\hline Average Inflation & $\ldots$ & 2.16 & 6.35 & 5.04 & 7.26 & 8.40 & 5.82 \\
\hline Average Wage Growth & 6.57 & 6.23 & 6.04 & 9.54 & 9.44 & 27.12 & 10.59 \\
\hline
\end{tabular}

Note: Data for TOPLINA not included as it started operations in March 2007. 
Table 26. Portfolio Allocation by UPFs (2004)

\begin{tabular}{|c|c|c|c|c|c|c|c|c|c|c|}
\hline \multirow{2}{*}{$\begin{array}{l}\text { UPF } 2004 \text { ( Percent) 1/ } \\
\text { Total investments (BGL 000) }\end{array}$} & \multicolumn{2}{|c|}{ Doverie SAGLasie } & $\begin{array}{r}\text { DSK- } \\
\text { Rodina }\end{array}$ & \multirow{2}{*}{$\begin{array}{r}\begin{array}{r}\text { Allianz } \\
\text { Bulgaria }\end{array} \\
58,9702\end{array}$} & \multicolumn{2}{|c|}{ ING CCB-Sila } & \multicolumn{2}{|c|}{$\begin{array}{c}\text { Lukoil } \\
\text { Garant } \\
\text { Bulgaria }\end{array}$} & Toplina & \multirow{2}{*}{$\begin{array}{r}\text { Tota } \\
60,538\end{array}$} \\
\hline & 111,612 & 30,420 & 776 & & 4,434 & 7,824 & 9,008 & 1,494 & & \\
\hline Securities issued or guaranteed by the government & 53 & 52 & 64 & 57 & 70 & 86 & 53 & 84 & $\ldots$ & 57 \\
\hline Securities, traded at regulated financial markets & 15 & 12 & 9 & 7 & 8 & 1 & 7 & 11 & $\ldots$ & 11 \\
\hline Shares & 7 & $\ldots$ & $\ldots$ & 1 & 6 & $\ldots$ & 3 & 8 & $\ldots$ & 4 \\
\hline Corporate Bonds & 8 & 12 & 9 & 6 & 2 & 1 & 4 & 3 & $\ldots$ & 7 \\
\hline Municipal bonds & 2 & $\ldots$ & 1 & $\ldots$ & $\ldots$ & 0 & 2 & $\ldots$ & $\ldots$ & 1 \\
\hline Bank deposits & 22 & 24 & 12 & 19 & 4 & 9 & 23 & 3 & $\ldots$ & 19 \\
\hline Mortgage Bonds & 8 & 9 & 13 & 17 & 13 & 0 & 15 & 3 & $\ldots$ & 11 \\
\hline Real estate & $\ldots$ & 3 & $\ldots$ & $\ldots$ & $\ldots$ & 3 & $\ldots$ & $\ldots$ & $\ldots$ & 0 \\
\hline Derivatives & $\ldots$ & $\ldots$ & $\ldots$ & $\ldots$ & $\ldots$ & $\ldots$ & $\ldots$ & $\cdots$ & $\ldots$ & $\ldots$ \\
\hline Investments abroad & $\ldots$ & $\ldots$ & 2 & $\ldots$ & 5 & $\ldots$ & $\ldots$ & $\ldots$ & $\ldots$ & 1 \\
\hline
\end{tabular}

$1 /$ Cash and receivables not included.

Table 27. Portfolio Allocation by UPFs (2005)

\begin{tabular}{|c|c|c|c|c|c|c|c|c|c|c|}
\hline \multirow{2}{*}{$\begin{array}{l}\text { UPF } 2005 \text { ( Percent) 1/ } \\
\text { Total investments (BGL 000) }\end{array}$} & \multicolumn{2}{|c|}{ Doverie SAGLasie } & $\begin{array}{l}\text { DSK- } \\
\text { Rodina }\end{array}$ & \multirow{2}{*}{$\begin{array}{r}\begin{array}{r}\text { Allianz } \\
\text { Bulgaria }\end{array} \\
101,1284\end{array}$} & \multicolumn{2}{|c|}{ ING CCB-Sila } & \multicolumn{2}{|c|}{$\begin{array}{r}\text { Lukoil } \\
\text { Garant } \\
\text { Bulgaria }\end{array}$} & ToplinA & \multirow{2}{*}{$\begin{array}{r}\text { Total } \\
34,045 \\
\end{array}$} \\
\hline & 178,027 & 48,501 & & & 1,785 & 13,266 & 16,166 & 4,539 & & \\
\hline Securities issued or guaranteed by the government & 54 & 55 & 51 & 51 & 61 & 81 & 51 & 82 & $\ldots$ & 55 \\
\hline Securities, traded at regulated financial markets & 21 & 20 & 14 & 15 & 11 & 14 & 15 & 9 & $\ldots$ & 17 \\
\hline Shares & 7 & 9 & 3 & 8 & 8 & 4 & 9 & 9 & $\ldots$ & 7 \\
\hline Corporate Bonds & 14 & 11 & 11 & 7 & 3 & 9 & 6 & $\ldots$ & $\ldots$ & 10 \\
\hline Municipal bonds & 1 & 2 & $\ldots$ & $\ldots$ & $\ldots$ & $\ldots$ & 1 & $\ldots$ & $\ldots$ & 1 \\
\hline Bank deposits & 18 & 15 & 21 & 19 & 12 & 5 & 22 & 9 & $\ldots$ & 17 \\
\hline Mortgage bonds & 3 & 6 & 13 & 15 & 12 & $\ldots$ & 11 & $\ldots$ & $\ldots$ & 8 \\
\hline Real estate & $\ldots$ & 2 & $\ldots$ & $\ldots$ & $\ldots$ & $\cdots$ & $\ldots$ & $\ldots$ & $\ldots$ & 0 \\
\hline Derivatives & $\ldots$ & $\ldots$ & $\cdots$ & $\ldots$ & $\ldots$ & $\cdots$ & $\ldots$ & $\ldots$ & $\ldots$ & $\cdots$ \\
\hline Investments abroad & 2 & $\ldots$ & 1 & $\ldots$ & 5 & $\ldots$ & $\ldots$ & $\ldots$ & $\ldots$ & 1 \\
\hline
\end{tabular}


Table 28. Portfolio Allocation by UPFs (2006)

\begin{tabular}{|c|c|c|c|c|c|c|c|c|c|c|}
\hline UPF 2006 ( Percent) /1 & Doverie $s$ & AGLasie $_{\mathrm{F}}$ & $\begin{array}{l}\text { K- } \\
\text { ina }\end{array}$ & $\begin{array}{c}\text { Allianz } \\
\text { Bulgaria }\end{array}$ & ING & CCB-Sila & $\begin{array}{c}\text { Lukoil } \\
\text { Garant } \\
\text { Bulgaria }\end{array}$ & $\begin{array}{c}\text { DZI } \\
\text { (Budeshte) }\end{array}$ & ToplinA & Total \\
\hline Total Investments (BGL 000) & 247,987 & 85,4475 & 876 & 154,8956 & 6,963 & 25,927 & 25,459 & 8,920 & & 667,475 \\
\hline Securities issued or guaranteed by the government & 34 & 35 & 28 & 26 & 37 & 42 & 31 & 35 & .. & 32 \\
\hline Securities, traded at regulated financial markets & 29 & 43 & 41 & 29 & 27 & 34 & 38 & 48 & $\ldots$ & 32 \\
\hline Shares & 14 & 27 & 20 & 20 & 22 & 24 & 25 & 32 & $\ldots$ & 20 \\
\hline Corporate Bonds & 14 & 17 & 21 & 9 & 5 & 10 & 13 & 16 & $\ldots$ & 13 \\
\hline Municipal bonds & 1 & 1 & $\ldots$ & $\ldots$ & $\ldots$ & & 0 & $\ldots$ & $\ldots$ & 0 \\
\hline Bank deposits & 27 & 13 & 22 & 24 & 9 & 20 & 18 & 14 & $\ldots$ & 22 \\
\hline Mortgage bonds & 1 & 3 & 9 & 8 & 10 & $\ldots$ & 5 & 3 & $\ldots$ & 5 \\
\hline Real estate & $\ldots$ & 4 & $\ldots$ & $\ldots$ & $\ldots$ & 3 & 5 & $\ldots$ & $\ldots$ & 1 \\
\hline Derivatives & $\ldots$ & $\ldots$ & $\ldots$ & $\ldots$ & $\ldots$ & $\ldots$ & $\ldots$ & $\ldots$ & $\ldots$ & $\ldots$ \\
\hline Investments abroad & 9 & $\ldots$ & $\ldots$ & 12 & 17 & & 3 & $\ldots$ & & 8 \\
\hline
\end{tabular}

Table 29. Portfolio Allocation by UPFs (2007)

\begin{tabular}{|c|c|c|c|c|c|c|c|c|c|c|}
\hline \multirow{2}{*}{$\begin{array}{l}\text { UPF } 2007 \text { ( Percent) 1/ } \\
\text { Total investments (BGL 000) } \\
\end{array}$} & \multicolumn{4}{|c|}{ Doverie SAGLasie $\begin{array}{c}\text { DSK- Allianz } \\
\text { Rodina Bulgaria }\end{array}$} & ING & \multicolumn{2}{|c|}{$\begin{array}{r}\text { Lukoil } \\
\text { CCB-Sila Garant } \\
\text { Bulgaria }\end{array}$} & $\begin{array}{c}\text { DZI } \\
\text { (Budeshte) }\end{array}$ & Toplina & \multirow[t]{2}{*}{ Total } \\
\hline & 458,556 & 147,316 & 9,975 & 260,0321 & 113,893 & 46,472 & 44,276 & 16,809 & 2,5761 & \\
\hline Securities issued or guaranteed by the government & 16 & 26 & 14 & 12 & 29 & 32 & 19 & 28 & 43 & 18 \\
\hline Securities, traded at regulated financial markets & 46 & 50 & 46 & 27 & 33 & 45 & 55 & 57 & 36 & 42 \\
\hline Shares & 28 & 32 & 31 & 22 & 30 & 27 & 39 & 43 & 28 & 28 \\
\hline Corporate Bonds & 18 & 18 & 14 & 6 & 3 & 18 & 16 & 14 & 8 & 13 \\
\hline Municipal bonds & 0 & 1 & $\ldots$ & $\ldots$ & ... & $\ldots$ & 0 & $\ldots$ & $\ldots$ & 0 \\
\hline Bank deposits & 17 & 11 & 24 & 21 & 2 & 16 & 14 & 15 & 21 & 16 \\
\hline Mortgage bonds & 1 & 2 & 4 & 5 & 6 & $\ldots$ & 4 & $\ldots$ & $\ldots$ & 3 \\
\hline Real estate & 4 & 3 & $\ldots$ & 1 & $\ldots$ & 2 & $\ldots$ & $\ldots$ & $\ldots$ & 2 \\
\hline Derivatives & $\ldots$ & $\ldots$ & $\ldots$ & $\ldots$ & $\ldots$ & $\ldots$ & $\ldots$ & $\ldots$ & $\ldots$ & \\
\hline Investments abroad & 15 & 7 & 12 & 35 & 30 & 5 & 8 & $\ldots$ & $\ldots$ & 18 \\
\hline
\end{tabular}

$1 /$ Cash and receivables not included. 
Table 30. Portfolio Allocation by PPFs (2004)

\begin{tabular}{|c|c|c|c|c|c|c|c|c|c|c|c|c|}
\hline PPF 2004 ( Percent) 1/ & Doverie & SAGLa & & $\begin{array}{l}\text { DSK- } \\
\text { Rodina }\end{array}$ & $\begin{array}{c}\text { Allianz } \\
\text { Bulgaria }\end{array}$ & ING & CCB-Sila & $\begin{array}{c}\text { Lukoil } \\
\text { Garant } \\
\text { Bulgaria }\end{array}$ & & $\begin{array}{c}\text { DZI } \\
\text { Budeshte) }\end{array}$ & Toplina & Total \\
\hline Total investments (BGL 000) & 88,541 & 34,161 & & 6,215 & 49,927 & 7,636 & 3,638 & 13,065 & & 197 & & 203,679 \\
\hline Securities issued or guaranteed by the government & 5 & & 51 & 64 & 64 & 74 & 83 & & 57 & 80 & $\ldots$ & 57 \\
\hline Securities, traded at regulated financial markets & 1. & & 17 & 13 & 5 & 8 & 2 & 2 & 6 & 11 & $\ldots$ & 10 \\
\hline Shares & 5 & 5 & $\ldots$ & $\ldots$ & 0 & 6 & $\ldots$ & . & 1 & 9 & $\ldots$ & 3 \\
\hline Corporate bonds & & 6 & 17 & 13 & 4 & 3 & 2 & 2 & 4 & 1 & $\ldots$ & 7 \\
\hline Municipal bonds & & 2 & $\ldots$ & 1 & 0 & $\ldots$ & 0 & D & 1 & $\ldots$ & $\ldots$ & 1 \\
\hline Bank deposits & 15 & & 22 & 5 & 20 & ... & 7 & 2 & 24 & 9 & $\ldots$ & 19 \\
\hline Mortgage bonds & $1:$ & & 5 & 15 & 11 & 13 & 4 & 1 & 12 & $\ldots$ & $\ldots$ & 11 \\
\hline Real estate & & 2 & 5 & ... & $\ldots$ & $\ldots$ & 4 & 4 & $\ldots$ & $\ldots$ & $\ldots$ & 2 \\
\hline Derivatives & .. & . & $\ldots$ & $\ldots$ & .. & $\ldots$ & $\ldots$ & . & $\ldots$ & $\ldots$ & $\ldots$ & $\ldots$ \\
\hline Investments abroad & .. & . & $\ldots$ & 2 & $\ldots$ & 5 & $\ldots$ & . & $\ldots$ & $\ldots$ & $\ldots$ & 0 \\
\hline
\end{tabular}

Table 31. Portfolio Allocation by PPFs (2005)

\begin{tabular}{|c|c|c|c|c|c|c|c|c|c|c|}
\hline \multirow{2}{*}{$\begin{array}{l}\text { PPF } 2005 \text { ( Percent) 1/ } \\
\text { Total investments (BGL 000) }\end{array}$} & \multicolumn{2}{|c|}{ Doverie Saglasie } & \multicolumn{2}{|c|}{$\begin{array}{r}\text { DSK- Allianz } \\
\text { Rodina Bulgaria }\end{array}$} & \multicolumn{2}{|c|}{ ING CCB-Sila } & $\begin{array}{r}\text { Lukoil } \\
\text { Garant } \\
\text { Bulgaria }\end{array}$ & \multicolumn{2}{|c|}{$\begin{array}{l}\text { DZI } \\
\text { shte) }\end{array}$} & \multirow{2}{*}{$\begin{array}{r}\text { Total } \\
250,195\end{array}$} \\
\hline & 105,686 & 41,809 & 8,917 & 60,4711 & 0,896 & 4,252 & 16,960 & 1,204 & & \\
\hline Securities issued or guaranteed by the government & 55 & 55 & 52 & 58 & 60 & 82 & 51 & 80 & $\ldots$ & 56 \\
\hline Securities, traded at regulated financial markets & 20 & 22 & 16 & 10 & 12 & 17 & 16 & 9 & $\ldots$ & 17 \\
\hline Shares & 9 & 9 & 3 & 7 & 9 & 6 & 8 & 9 & $\ldots$ & 8 \\
\hline Corporate bonds & 12 & 13 & 12 & 3 & 3 & 11 & 8 & $\ldots$ & $\ldots$ & 9 \\
\hline Municipal bonds & 2 & 1 & $\ldots$ & 0 & $\ldots$ & $\ldots$ & 1 & $\ldots$ & $\ldots$ & 1 \\
\hline Bank deposits & 15 & 17 & 18 & 19 & 10 & 0 & 22 & 11 & $\ldots$ & 16 \\
\hline Mortgage bonds & 6 & 4 & 12 & 13 & 13 & $\ldots$ & 11 & $\ldots$ & $\ldots$ & 8 \\
\hline Real estate & 0 & 1 & $\ldots$ & $\ldots$ & $\ldots$ & $\ldots$ & $\ldots$ & $\ldots$ & $\ldots$ & 0 \\
\hline Derivatives & $\ldots$ & $\ldots$ & $\ldots$ & $\ldots$ & $\ldots$ & $\ldots$ & $\ldots$ & $\ldots$ & $\cdots$ & .. \\
\hline Investments abroad & 2 & $\ldots$ & 2 & $\ldots$ & 6 & $\ldots$ & $\ldots$ & $\ldots$ & $\ldots$ & 1 \\
\hline
\end{tabular}

1/ Cash and receivables not included. 
Table 32. Portfolio Allocation by PPFs (2006)

\begin{tabular}{|c|c|c|c|c|c|c|c|c|c|c|}
\hline PPF 2006 ( Percent) 1/ & Doverie $S$ & AGLasie $_{\mathrm{F}}$ & K- & $\begin{array}{c}\text { Allianz } \\
\text { Bulgaria }\end{array}$ & ING & CCB-Sila & $\begin{array}{c}\text { Lukoil } \\
\text { Garant } \\
\text { Bulgaria }\end{array}$ & $\begin{array}{c}\text { DZI } \\
\text { (Budeshte) }\end{array}$ & ToplinA & Total \\
\hline Total investments (BGL 000) & 123,017 & 59,1211 & 154 & 68,2171 & 4,752 & 6,586 & 20,459 & 1,932 & & 306,239 \\
\hline Securities issued or guaranteed by the government & 33 & 36 & 34 & 28 & 34 & 39 & 39 & 39 & $\ldots$ & 33 \\
\hline Securities, traded at regulated financial markets & 29 & 42 & 42 & 27 & 28 & 40 & 29 & 43 & $\ldots$ & 32 \\
\hline Shares & 17 & 27 & 23 & 22 & 23 & 26 & 18 & 32 & $\ldots$ & 21 \\
\hline Corporate bonds & 12 & 15 & 18 & 5 & 5 & 13 & 11 & 12 & $\ldots$ & 11 \\
\hline Municipal bonds & 1 & 1 & $\ldots$ & $\ldots$ & $\cdots$ & $\ldots$ & 0 & $\ldots$ & $\cdots$ & 1 \\
\hline Bank deposits & 25 & 16 & 15 & 24 & 8 & 18 & 18 & 14 & $\ldots$ & 21 \\
\hline Mortgage bonds & 3 & 2 & 8 & 10 & 11 & $\ldots$ & 7 & 3 & $\ldots$ & 5 \\
\hline Real estate & 0 & 4 & $\ldots$ & $\ldots$ & $\ldots$ & 3 & 5 & $\ldots$ & $\ldots$ & 1 \\
\hline Derivatives & $\cdots$ & $\cdots$ & $\ldots$ & $\ldots$ & $\cdots$ & $\ldots$ & $\ldots$ & $\cdots$ & $\ldots$ & .. \\
\hline Investments abroad & 9 & $\ldots$ & 2 & 11 & 19 & $\ldots$ & 1 & $\ldots$ & $\ldots$ & 7 \\
\hline
\end{tabular}

Table 33. Portfolio Allocation by PPFs (2007)

\begin{tabular}{|c|c|c|c|c|c|c|c|c|c|c|}
\hline \multirow{2}{*}{$\begin{array}{l}\text { PPF } 2007 \text { ( Percent) 1/ } \\
\text { Total investments (BGL 000) }\end{array}$} & \multicolumn{2}{|c|}{ Doverie SAGLasie } & \multicolumn{2}{|c|}{$\begin{array}{l}\text { SK- Allianz } \\
\text { odinA Bulgaria }\end{array}$} & ING & CCB-Sila & \multicolumn{2}{|c|}{$\begin{array}{l}\text { LukoiL } \\
\text { Garant } \\
\text { Bulgaria } \\
\text { Budeshte) }\end{array}$} & Toplina & Total \\
\hline & 155,252 & 78,391 & 265 & 81,0902 & 20,001 & 9,725 & 27,187 & 2,507 & 5,9823 & 399,401 \\
\hline Securities issued or guaranteed by the government & 13 & 21 & 19 & 17 & 26 & 32 & 27 & 17 & 47 & 18 \\
\hline Securities, traded at regulated financial markets & 47 & 52 & 48 & 31 & 34 & 48 & 54 & 64 & 31 & 44 \\
\hline Shares & 31 & 34 & 35 & 25 & 30 & 30 & 39 & 49 & 23 & 31 \\
\hline Corporate bonds & 16 & 19 & 12 & 5 & 3 & 18 & 15 & 15 & 9 & 13 \\
\hline Municipal Bonds & 0 & 0 & $\ldots$ & $\ldots$ & $\ldots$ & $\ldots$ & 0 & $\ldots$ & $\ldots$ & 0 \\
\hline Bank deposits & 16 & 13 & 24 & 17 & 3 & 12 & 7 & 19 & 21 & 15 \\
\hline Mortgage bonds & 2 & 2 & 4 & 7 & 8 & $\ldots$ & 4 & $\ldots$ & $\ldots$ & 4 \\
\hline Real estate & 4 & 3 & $\ldots$ & 1 & $\ldots$ & 2 & $\ldots$ & $\ldots$ & $\ldots$ & 3 \\
\hline Derivatives & $\ldots$ & $\ldots$ & $\ldots$ & $\ldots$ & $\ldots$ & $\ldots$ & $\ldots$ & $\ldots$ & $\ldots$ & $\ldots$ \\
\hline Investments abroad & 17 & 8 & 5 & 27 & 30 & 5 & 7 & $\ldots$ & $\ldots$ & 16 \\
\hline
\end{tabular}

$1 /$ Cash and receivables not included. 
Table 34. Portfolio Allocation by VPFs (2004)

\begin{tabular}{|c|c|c|c|c|c|c|c|c|c|c|}
\hline PPF 2004 (Percent) 1/ & Doverie S & ${ }_{\text {AGLasie }}{ }_{R}$ & $\begin{array}{l}\text { SK- } \\
\text { dina }\end{array}$ & $\begin{array}{c}\text { Allianz } \\
\text { Bulgaria }\end{array}$ & ING & CCB-Sila & $\begin{array}{c}\text { LukoiL } \\
\text { Garant } \\
\text { Bulgaria }\end{array}$ & $\begin{array}{c}\text { DZI } \\
\text { (Budeshte) }\end{array}$ & ToplinA & Total \\
\hline Total investments (BGL 000) & 61,919 & 11,7001 & 276 & 170,8792 & 26,154 & 4,699 & 27,114 & 822 & & 321,564 \\
\hline Securities issued or guaranteed by the Government & 33 & 54 & 68 & 56 & 68 & 82 & 54 & 59 & $\ldots$ & 54 \\
\hline Securities, traded at regulated financial markets & 21 & 12 & 8 & 7 & 10 & 1 & 11 & 13 & $\ldots$ & 10 \\
\hline Shares & 9 & $\ldots$ & $\ldots$ & 1 & 7 & $\ldots$ & 3 & 10 & $\ldots$ & 3 \\
\hline Corporate bonds & 12 & 12 & 8 & 6 & 3 & 1 & 8 & 3 & $\ldots$ & 7 \\
\hline Municipal bonds & 1 & $\ldots$ & 0 & 0 & $\cdots$ & $\cdots$ & 1 & $\ldots$ & $\ldots$ & 0 \\
\hline Bank deposits & 25 & 13 & 15 & 22 & 2 & 9 & 25 & 25 & $\ldots$ & 20 \\
\hline Mortgage bonds & 20 & 13 & 7 & 10 & 14 & 0 & 9 & 3 & $\ldots$ & 12 \\
\hline Real estate & $\ldots$ & 8 & $\ldots$ & 5 & & 7 & ... & $\ldots$ & $\ldots$ & 3 \\
\hline Derivatives & $\ldots$ & $\ldots$ & $\ldots$ & $\ldots$ & $\ldots$ & $\ldots$ & ... & $\ldots$ & $\ldots$ & $\ldots$ \\
\hline Investments abroad & $\ldots$ & $\ldots$ & 2 & $\ldots$ & 5 & $\ldots$ & $\ldots$ & $\ldots$ & $\ldots$ & 1 \\
\hline
\end{tabular}

Table 35. Portfolio Allocation by VPFs (2005)

\begin{tabular}{|c|c|c|c|c|c|c|c|c|c|c|}
\hline PPF 2005 (Percent) 1/ & Doverie $\subseteq$ & AGLasie $_{\mathrm{F}}$ & $\begin{array}{l}\text { SK- } \\
\text { dina }\end{array}$ & $\begin{array}{c}\text { Allianz } \\
\text { Bulgaria }\end{array}$ & ING & CCB-SilA & $\begin{array}{c}\text { LukoiL } \\
\text { GaranT } \\
\text { Bulgaria }\end{array}$ & $\begin{array}{c}\text { DZI } \\
\text { (Budeshte) }\end{array}$ & ToplinA & Total \\
\hline Total investments (BGL 000) & 74,405 & 12,136 & 3,771 & 212,5793 & 35,637 & 4,723 & 32,057 & 2,914 & & $.398,222$ \\
\hline Securities issued or guaranteed by the government & 35 & 56 & 37 & 48 & 51 & 79 & 45 & 79 & $\ldots$ & 46 \\
\hline Securities, traded at regulated financial markets & 29 & 17 & 24 & 13 & 10 & 20 & 17 & 9 & $\ldots$ & 17 \\
\hline Shares & 9 & 8 & 7 & 7 & 9 & 6 & 4 & 9 & $\ldots$ & 7 \\
\hline Corporate bonds & 20 & 9 & 17 & 6 & 2 & 14 & 13 & ... & $\ldots$ & 9 \\
\hline Municipal bonds & 1 & 4 & $\ldots$ & 0 & $\ldots$ & $\ldots$ & 0 & $\ldots$ & $\ldots$ & 0 \\
\hline Bank deposits & 20 & 11 & 25 & 26 & 18 & 2 & 24 & 12 & $\ldots$ & 23 \\
\hline Mortgage bonds & 13 & 10 & 13 & 10 & 14 & $\ldots$ & 12 & $\ldots$ & $\ldots$ & 11 \\
\hline Real estate & $\ldots$ & 2 & $\ldots$ & 3 & $\ldots$ & $\ldots$ & 1 & .. & $\ldots$ & 2 \\
\hline Derivatives & $\ldots$ & $\ldots$ & $\ldots$ & $\ldots$ & $\ldots$ & $\ldots$ & $\ldots$ & ... & $\ldots$ & . \\
\hline Investments abroad & 2 & $\ldots$ & 1 & $\ldots$ & 6 & $\ldots$ & $\ldots$ & $\ldots$ & $\ldots$ & 1 \\
\hline
\end{tabular}


Table 36. Portfolio Allocation by VPFs (2006)

\begin{tabular}{|c|c|c|c|c|c|c|c|c|c|c|}
\hline \multirow{4}{*}{$\begin{array}{l}\text { PPF } 2006 \text { ( Percent) } 1 / \\
\text { Total Investments (BGL 000) } \\
\text { Securities Issued or guaranteed by the government } \\
\text { Securities, traded at regulated financial markets }\end{array}$} & \multirow{2}{*}{$\begin{array}{r}\text { DoverieE } \\
82,625\end{array}$} & \multirow{2}{*}{\multicolumn{2}{|c|}{$\begin{array}{c}\text { Saglasie } \begin{array}{c}\text { DSK- } \\
\text { Rodina }\end{array} \\
16,98330,871\end{array}$}} & \multirow{2}{*}{\multicolumn{2}{|c|}{$\begin{array}{c}\begin{array}{c}\text { Allianz } \\
\text { Bulgaria ING }\end{array} \\
256,64744,731\end{array}$}} & \multirow{2}{*}{$\begin{array}{r}\text { CCB-Sila } \\
7,552 \\
\end{array}$} & \multirow{2}{*}{$\begin{array}{c}\text { Lukoil } \\
\text { Garant } \\
\text { Bulgaria } \\
34,259 \\
\end{array}$} & \multirow{2}{*}{$\begin{array}{r}\begin{array}{l}\text { DZI } \\
\text { (Budeshte) }\end{array} \\
\quad 4,661 \\
\end{array}$} & \multirow{2}{*}{$\begin{array}{r}\text { Toplina } \\
\ldots\end{array}$} & \multirow{2}{*}{$\begin{array}{l}\text { a Total } \\
.478,329 \\
\end{array}$} \\
\hline & & & & & & & & & & \\
\hline & 15 & 31 & 22 & 21 & 23 & 37 & 32 & 34 & .. & 22 \\
\hline & 44 & 41 & 47 & 30 & 33 & 43 & 31 & 47 & $\ldots$ & 34 \\
\hline Shares & 20 & 29 & 26 & 21 & 27 & 31 & 18 & 31 & $\ldots$ & 22 \\
\hline Corporate bonds & 25 & 12 & 21 & 9 & 6 & 12 & 13 & 15 & $\ldots$ & 13 \\
\hline Municipal bonds & 1 & 3 & $\ldots$ & 0 & $\ldots$ & $\ldots$ & 0 & $\ldots$ & $\ldots$ & 0 \\
\hline Bank deposits & 26 & 14 & 19 & 24 & 24 & 17 & 20 & 16 & $\ldots$ & 23 \\
\hline Mortgage bonds & 4 & 4 & 11 & 7 & 11 & $\ldots$ & 8 & 4 & $\ldots$ & .. \\
\hline Real estate & $\ldots$ & 8 & $\ldots$ & 5 & $\ldots$ & 3 & 7 & ... & $\ldots$ & 4 \\
\hline Derivatives & $\ldots$ & $\ldots$ & $\ldots$ & $\ldots$ & $\ldots$ & $\ldots$ & $\ldots$ & $\ldots$ & $\ldots$ & .. \\
\hline Investments abroad & 10 & $\ldots$ & 1 & 14 & 8 & $\ldots$ & 1 & $\ldots$ & $\ldots$ & 10 \\
\hline
\end{tabular}

Table 37. Portfolio Allocation by VPFs (2007)

\begin{tabular}{|c|c|c|c|c|c|c|c|c|c|c|}
\hline \multirow{2}{*}{$\begin{array}{l}\text { PPF } 2007 \text { ( Percent) 1/ } \\
\text { Total Investments (BGL 000) } \\
\end{array}$} & \multicolumn{3}{|c|}{ Doverie SAGLasie $\begin{array}{l}\text { DSK- } \\
\text { Rodina }\end{array}$} & $\begin{array}{l}\text { Allianz } \\
\text { Bulgaria }\end{array}$ & ING & \multicolumn{2}{|c|}{$\begin{array}{rr}\text { Lukoil } \\
\text { CCB-Sila } \\
\text { Garant } \\
\text { Bulgaria }\end{array}$} & \multicolumn{2}{|c|}{$\begin{array}{c}\text { DZI } \\
\text { (Budeshte) }\end{array}$} & Total \\
\hline & 105,208 & 24,4405 & 044 & 327,9565 & 59,589 & 11,619 & 40,119 & 7,667 & 4676 & 635,109 \\
\hline Securities issued or guaranteed by the Government & 4 & 11 & 6 & 10 & 14 & 23 & 15 & 5 & 43 & 10 \\
\hline Securities, traded at regulated financial Markets & 50 & 52 & 48 & 32 & 39 & 63 & 66 & 83 & 44 & 41 \\
\hline Shares & 38 & 41 & 36 & 25 & 35 & 49 & 51 & 72 & 38 & 32 \\
\hline Corporate bonds & 12 & 11 & 13 & 7 & 4 & 13 & 15 & 11 & 7 & 9 \\
\hline Municipal bonds & 0 & 2 & $\ldots$ & 0 & $\ldots$ & $\ldots$ & 0 & $\ldots$ & $\ldots$ & 0 \\
\hline Bank deposits & 16 & 20 & 30 & 19 & 3 & 8 & 13 & 12 & 13 & 17 \\
\hline Mortgage bonds & $\ldots$ & 2 & 3 & 5 & 9 & $\ldots$ & 2 & $\ldots$ & $\ldots$ & 4 \\
\hline Real estate & 11 & 6 & $\ldots$ & 9 & $\ldots$ & 2 & $\ldots$ & $\ldots$ & $\ldots$ & 6 \\
\hline Derivatives & $\ldots$ & $\ldots$ & $\ldots$ & $\ldots$ & $\ldots$ & $\ldots$ & $\ldots$ & $\ldots$ & $\cdots$ & $\ldots$ \\
\hline Investments abroad & 19 & 7 & 12 & 25 & 36 & 3 & 4 & $\ldots$ & & 21 \\
\hline
\end{tabular}

$1 /$ Cash and receivables not included. 
Table 38. Pension Funds Investment Regulation

\begin{tabular}{|c|c|c|c|c|}
\hline \multicolumn{2}{|l|}{ Asset type } & \multirow{2}{*}{$\begin{array}{l}\text { Limit base } \\
\text { Of assets }\end{array}$} & \multicolumn{2}{|c|}{$\begin{array}{c}\text { Voluntary } \text { Mandatory } \\
\text { PF } \quad \text { PF } \\
\text { (in percent)(in percent) }\end{array}$} \\
\hline $\begin{array}{l}\text { Bonds issued by Bulgaria, EU or EEA member states, their central banks, ECB, EIB, } \\
\text { third states* or their central banks. }\end{array}$ & Max & & 100 & 100 \\
\hline $\begin{array}{l}\text { Shares admitted for trading at the regulated markets in Bulgaria, } \\
\text { EU or EEA member states, third states }{ }^{\star \star}\end{array}$ & Max & Of assets & 100 & 20 \\
\hline Common equity by a single company & Max & Of issuer's capital & 7 & 7 \\
\hline Shares of Special Purpose Investment Companies securitizing real estate (REITs) or receivables & sMax & Of assets & 10 & 5 \\
\hline Units of investment/mutual funds in Bulgaria, EU or EEA member state or third states & Max & Of assets & 100 & 15 \\
\hline Units of investment/mutual funds, managed by one asset manager & Max & Of assets & 10 & 5 \\
\hline $\begin{array}{l}\text { Deposits in banks with a credit rating licensed for operating in Bulgaria, } \\
\text { EU or EEA member state or third states }\end{array}$ & Max & Of assets & 100 & 25 \\
\hline Deposits in a single bank & Max & Of assets & 5 & 5 \\
\hline Mortgage bonds issued by Bulgarian banks & Max & Of assets & 100 & 30 \\
\hline Municipal bonds by municipalities in Bulgaria, EU or EEA member state or third states ${ }^{\star \star \star}$ & Max & Of assets & 100 & 15 \\
\hline $\begin{array}{l}\text { Corporate bonds admitted for trading at the regulated markets and by issuers domiciled } \\
\text { in Bulgaria, EU or EEA member state or third states }\end{array}$ & Max & Of assets & 100 & 25 \\
\hline Non-listed collateralized corporate bonds by issuers domiciled in Bulgaria & $\operatorname{Max}$ & Of assets & 10 & 5 \\
\hline Securities by a single issuer (shares $\&$ bonds) & Max & Of assets & 5 & 5 \\
\hline Real estate in Bulgaria, EU or EEA member state & Max & Of assets & 10 & 5 \\
\hline Foreign currency exposure (currencies different from BGN and EUR) & Max & Of assets & 30 & 20 \\
\hline Repo deals & $\operatorname{Max}$ & Of assets & 5 & 5 \\
\hline Derivatives (futures, options, swaps) ${ }^{\star \star \star \star}$ & Max & Of assets & tbd & tbd \\
\hline
\end{tabular}

*/ Names of third states are defined in an Ordinance 29 by the Financial Supervision Commission; **/ Shares on regulated markets in EU, EEA or third states

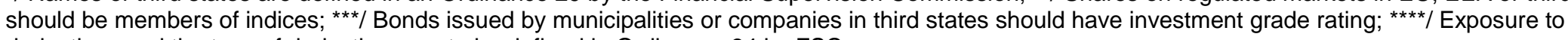
derivatives and the type of derivatives are to be defined in Ordinance 34 by FSC. 


\section{Appendix III. Investment Rules for Pension Funds ${ }^{45}$}

\section{Investment Guidelines for UPFs and PPFs}

\section{Investment}

Article 176. (Amended and supplemented, SG No. 67/2003, amended, SG No. 17 of February 24, 2006) (1) The pension insurance company may invest the assets of a supplementary mandatory pension fund only in:

1. securities issued or guaranteed by the Government, the liabilities under which constitute government or sovereign debt;

2. shares, other than the indicated under item 3 and 9 , admitted to trading on a regulated securities market, as well as in rights under $\S 1$, item 3 of the Additional Provisions of the Law on Public Offering of Securities;

3. shares of a special investment purpose company, licensed under the procedure of the Special Investment Purpose Companies Act, as well as in rights under $\S 1$, item 3 of the Additional Provisions of the Law on Public Offering of Securities, issued with increase in the company's capital;

4. municipal securities, issued by Bulgarian municipalities pursuant to the Municipal Debt Act;

5. bank deposits in banks with a credit rating, that have obtained a license to pursue banking activity on the territory of the Republic of Bulgaria;

6. mortgage bonds, issued pursuant to the Mortgage Bonds Act, admitted to trading on a regulated securities market;

7. corporate bonds, other than the indicated under item 6 , admitted to trading on a regulated market;

8. secured corporate bonds, for which in the decision of the general shareholders meeting and in the proposal for conclusion of a bond loan, an obligation has been undertaken to be listed for trading on a regulated securities market within a period not longer than 6 months from their issue and for which it has been envisaged the provisions of the Law on Public

${ }^{45}$ This Appendix is drawn from Arvai (2007). 
Offering of Securities concerning the bondholders' trustee and collateralizing a public bond issue to apply accordingly;

9. shares and/or units, issued by collective investment schemes pursuant to the procedure of the Law on Public Offering of Securities;

10. debt securities, issued or guaranteed by:

a) European Union member-states, or by other states - parties to the European Economic Area Agreement, or their central banks;

b) states, indicated in an ordinance of the Commission, or by their central banks;

c) the European Central Bank or by the European Investment Bank;

11. securities, admitted to trading on regulated securities markets in European Union member-states, or other states - parties to the European Economic Area Agreement;

a) debt securities, issued by foreign municipalities;

b) debt securities, other than the indicated under letter "a" and item 10 ;

c) shares, covered by indexes of regulated securities markets;

12. securities, admitted to trading on regulated securities markets in states, indicated in an ordinance of the Commission;

a) qualified debt securities, issued by foreign municipalities;

b) qualified debt securities, other than the indicated under letter "a" and item 10;

c) shares, covered by indexes of regulated securities markets;

13. shares and/or units of a collective investment scheme, which invests only in securities and deposits under item 1-8, 10,11, 12 and 14 or whose registered office or the registered office of its management company is located in a European Union member-state, or in other state - party to the European Economic Union Agreement, respectively in a state, indicated in an ordinance of the Commission;

14. bank deposits in banks with credit rating, that have obtained a license to pursue banking activity according the legislation of a European Union member-state, or of other country - party to the European Economic Area Agreement, or of a state, indicated in an ordinance of the Commission;

15. investment property in the country, in a European Union member-state, or in other state - party to the European Economic Area Agreement.

(2) The Commission shall determine by an ordinance:

1. the minimum level of the ratings under par. 1 , item 5 and 14 and the rating agencies, awarding them;

2. the states under par. 1 , item 10 , letter " $b$ ", item 12,13 and 14 and the regulated markets in these states, on which the securities under par. 1, item 12 are traded;

3. the indexes under par. 1, item 11, letter "c" and item 12, letter "c".

(3) The management body of the pension insurance company shall approve internal rules for the procedures of surveillance, measurement and management of the risk, related to the investments of a supplementary mandatory pension fund and shall present them to the Deputy Chairperson of the Commission within a 7-day period from their approval, respectively amendment and supplement. 


\section{Investment Restrictions}

Article 178. (Amended, SG No. 8/2003, amended and supplemented, SG No. 67/2003, amended, SG No. 38/2005, amended, SG No. 17 of February 24, 2006) (1) The total amount of the investments by a supplementary mandatory pension fund in securities. issued bv a single issuer mav not exceed 5 per cent of the fund assets. This restriction shall not apply for investments in securities under Art. 176, par. 1, item 1 and 10 .

(2) Not more than 20 per cent of the supplementary mandatory pension fund assets may be invested totally in securities under Art. 176, par. 1 item 2, item 11 letter " $c$ " and item 12 letter " $c$ ".

(3) Not more than 5 per cent of the supplementary mandatory pension fund assets may be invested in securities under Art. 176, par. 1 item 3.

(4) Not more than 15 per cent of the supplementary mandatory pension fund assets may be invested totally in securities under Art. 176, par. 1, item 4, item 11 letter " $a$ " and item 12 letter " $a$ ".

(5) Not more than 25 per cent of the supplementary mandatory pension fund assets may be invested in total in bank deposits under Art. 176, par. 1, item 5 and 14, where the investments in the bank deposits in one bank may not exceed 5 percent of the fund assets.

(6) Not more than 30 per cent of the supplementary mandatory pension fund assets may be invested in mortgage bonds under Art. 176, par. 1 item 6 .

(7) Not more than 25 per cent of the supplementary mandatory pension fund assets may be invested totally in securities under Art. 176, par. 1, item 7, item 11 letter "b" and item 12 letter "b".

(8) Not more than 5 per cent of the supplementary mandatory pension fund assets may be invested in securities under Art. 176, par. 1, item 8 .

(9) Not more than 15 per cent of the supplementary mandatory pension fund assets may be invested in total in securities under Art. 176, par. 1, item 9 and 13, where the investments in securities of collective investment schemes, managed by one and the same management company may not exceed 5 percent of the fund assets.

(10) Not more than 20 per cent of the supplementary mandatory pension fund assets may be denominated in currency, other than BGN and euro.

(11) Not more than 5 per cent of the supplementary mandatory pension fund assets may be invested in investment property under Art. 176, par. 1 item 15. 


\section{Investment Restrictions for VPFs}

\section{Investment Restrictions}

Article 251. (Amended, SG No. 17 of February 24, 2006) (1) Not more than 5 per cent of supplementary voluntary pension fund assets may be invested in securities, issued by single issuers. This limitation does not apply to the investments in securities under Art. 176, par. 1, item 1 and 10.

(2) Not more than 5 per cent of supplementary voluntary pension fund assets may be invested in bank deposits in a single bank.

(3) Not more than 30 per cent of supplementary voluntary pension fund assets may be denominated in currency, other than BGN and euro.

(4) Not more than 10 per cent of supplementary voluntary pension fund assets may be invested in securities under Art. 176, par. 1, item 3 .

(5) Not more than 10 per cent of supplementary voluntary pension fund assets may be invested in securities under Art. 176, par. 1, item 8.

(6) Not more than 10 per cent of supplementary voluntary pension fund assets may be invested in securities of collective investment schemes, managed by one and the same management company.

(7) Not more than 10 per cent of supplementary voluntary pension fund assets may be invested in investment property under Art. 176, par. 1, item 15, where the investment in one property may not exceed 5 percent of the fund assets.

\section{Derivative Transactions Allowed for Pension Funds}

\section{Transactions for Investment Risk Reduction}

Art. 179b. (New, SG No. 17 of February 24, 2006) (1) With the purpose of reduction of the investment risk, related to pension fund assets, the pension insurance company may conclude transactions, which envisage deferral of the execution of the obligations under such transactions for a specified future date or term.

(2) Transactions under par. 1 shall be:

1. transactions with futures, traded on regulated securities markets in the Republic of Bulgaria, in member-states of the European Union, or in other states parties to the European Economic Area Agreement, or on regulated securities markets in states as indicated in an ordinance of the Commission;

2. transactions with options, traded on regulated securities markets in the Republic of Bulgaria, in member-states of the European Union, or in other states parties to the European Economic Area Agreement, or on regulated securities markets in states as indicated in an ordinance of the Commission;

3. forward exchange contracts;

4. interest-rate swap-transactions.

(3) The Commission shall adopt an ordinance on the conditions of conclusion of transactions under par. 1 , as well as on the requirements and restrictions to them. 


\section{Appendix IV. Relationship Between Concentration, Market Power and Demand Elasticity}

\section{Relationship between market power and demand elasticity}

131. The inverse relationship between the Lerner index and the elasticity of demand is easily shown in the case of the profit-maximizing Cournot oligopoly of $n$ different firms producing a single homogeneous good.

132. Let $p(Q)$ the inverse demand function with $Q=\sum_{i}^{n} q_{i}$ being the total output produced by the n firms. Let $C_{i}\left(q_{i}\right)$ be the supply function of the i-th firm: i.e., the cost (different for each firm) incurred by i-th the firm to produce qi units of the good. Assume that both the demand and the supply functions are differentiable with $p^{\prime}<0$ and $C_{i}^{\prime}>0$. Firm i maximizes its profits by taking the quantities produced by the other firms as given. Therefore, the problem for the i-th firm implies choosing the quantity $q_{i}^{c}$ such that:

$$
\max _{q_{i}} \Pi_{i}(Q)=\left[p(Q) q_{i}-C_{i}\left(q_{i}\right)\right]
$$

133. This is found by solving the system of reaction functions $q_{i}^{R}\left(Q_{-i}\right)=q_{i}$ jointly with the other $\mathrm{n}-1$ firms. This yields the Nash equilibrium $q_{i}^{R}\left(Q_{-i}^{c}\right)=q_{i}^{c} \forall i=1, \cdots, n$ sold at the equilibrium price $p^{c}=p\left(Q^{c}\right)$.

134. Notice in particular that the Lerner index for firm i is derived directly from its first order condition $\frac{\partial p}{\partial q_{i}} q_{i}+p-\frac{\partial C_{i}}{\partial q_{i}}=0$. In other words:

$$
L I_{i}=\frac{p-C_{i}^{\prime}}{p}=-\frac{p_{i}^{\prime} q_{i}}{p}=\frac{1}{\varepsilon_{i}}
$$

where the left hand side of the last equation is the relative "mark-up", also known as Lerner index, charged by firm $i$ and $\varepsilon_{i}$ is the elasticity of the residual demand faced by firm $i$.

135. In equilibrium, the market power if firm $i$ is inversely proportional to the elasticity of its residual demand. For given $q_{i}^{c}$, firm $i$ will have a low market power if its residual demand is very elastic. It will have a high market power if its residual demand is very inelastic.

\section{Relationship Between Concentration and Market Power}

136. The Herfinahl-Hirschmann index is defined as the sum of the market shares squared: 


$$
H H I=\sum_{i=1}^{n}\left(s_{i}\right)^{2}
$$

where simply $s_{i}=q_{i} / Q$ is the market share of the $i$-th firm.

Notice also that:

$$
H H I= \begin{cases}1 & \text { monopoly } \\ \frac{1}{n} & n \text { identical firms } \\ \sum_{i=1}^{n}\left(s_{i}\right)^{2} & n \text { different firms } \\ 0 & \text { perfect competition }(n \rightarrow \infty)\end{cases}
$$

137. From the previous section we learned that in the case of the profit-maximizing Cournot oligopoly of $n$ different firms producing a single homogeneous good, the Lerner index for firm i can be expressed as the inverse of the price elasticity of its residual demand. We can further manipulate this to express the firm's Lerner index as the inverse of the elasticity of the market demand weighted by the firm's market share:

$$
L I_{i}=\frac{1}{\varepsilon_{i}}=-\frac{p^{\prime} q_{i}}{p} \frac{Q}{Q}=\frac{s_{i}}{\varepsilon_{Q}}
$$

where $\varepsilon_{Q}$ is the elasticity of the market demand.

138. The market Lerner index is defined as the average of the firm Lerner indices weighted by their market shares:

$$
L I=\sum_{i=1}^{n} s_{i} L I_{i}=\sum_{i=1}^{n} \frac{s_{i}^{2}}{\varepsilon_{Q}}=\frac{H H I}{\varepsilon_{Q}}
$$

which gives us the relationship between market concentration and market power.

139. Market power is directly related to market concentration and the strength of this relationship is inversely proportional to the demand elasticity. If market demand is very elastic, changes in concentration will not have very large effects on pricing and hence, market power. If demand is very inelastic, changes in concentration can have large effects on pricing and therefore, produce important distortion on both the demand and supply side as mentioned in the text.

140. The following tables report the Lerner index for each PIC in the Bulgarian mandatory and voluntary markets as well as three market averages respectively weighted by income and costs, participants and assets. The indices have been approximated by using total operational 
costs of both mandatory and voluntary funds. In addition, two sets of calculations have been conducted: in the first table income from own assets was not included in the fees charged to participants while in the second table such revenues were also included. While the first set of calculations more correctly capture the price charged to participants for the services rendered, the second set of calculations is useful to show how many PICs still use income from own assets as a way to subsidize operational costs and capture market share.

Table 39. Lerner Indices with No Investment Income

\begin{tabular}{lccccc}
\hline 1/ 2/ & 2003 & 2004 & 2005 & 2006 & 2007 \\
\hline Doverie & -18.55 & 7.00 & -3.98 & 6.13 & 23.87 \\
SAGLasie & -17.63 & -1.17 & -39.98 & -1.88 & -10.94 \\
DSK-Rodina & -96.42 & -79.92 & -22.06 & 4.63 & 4.56 \\
Allianz-Bulgaria & 40.16 & 33.99 & 31.02 & 29.75 & 44.62 \\
Ing & -183.67 & -114.11 & -70.17 & -32.56 & -3.69 \\
CKB-Sila & -213.48 & -157.48 & -367.05 & -189.85 & -284.97 \\
Lukoil Garant - Bulgaria & -31.44 & -88.53 & -47.60 & -19.64 & 9.32 \\
DZI (Budeshete) & $\ldots$ & -549.45 & -133.46 & -45.30 & -4.13 \\
LI/W 3/ & 8.19 & 22.24 & 14.71 & 16.91 & 30.99 \\
LI/C 4/ & -25.66 & -19.72 & -25.19 & -2.98 & 4.97 \\
LI/A 5/ & -13.77 & -4.16 & -11.29 & 3.42 & 11.95 \\
\hline SOur
\end{tabular}

Source: Own calculations.

1/ Calculations approximated with total costs rather than marginal costs; 2/ TOPLINA not included; 3/ Weighted by fees and costs; 4/ Weighted by the number of participants; 5/ Weighted by assets.

Table 40. Lerner Indices with Investment Income

\begin{tabular}{lccccc}
\hline 1/ 2/ & 2003 & 2004 & 2005 & 2006 & 2007 \\
\hline Doverie & -7.58 & 18.61 & 0.84 & 25.77 & 28.27 \\
SAGLasie & -15.08 & 7.67 & 0.62 & 6.12 & 6.65 \\
DSK-Rodina & -82.31 & -44.61 & -3.97 & 33.46 & 30.73 \\
Allianz-Bulgaria & 44.16 & 39.35 & 37.26 & 39.24 & 50.30 \\
Ing & -131.18 & -80.43 & -51.72 & -22.71 & 5.12 \\
CKB-Sila & -25.68 & 21.60 & 32.11 & 53.60 & 70.98 \\
Lukoil Garant - Bulgaria & -2.07 & -1.54 & -18.43 & 2.95 & 26.15 \\
DZI (Budeshete) & & -22.11 & 4.12 & 20.93 & 27.91 \\
LI/W 3/ & 13.19 & 26.34 & 16.82 & 31.04 & 50.61 \\
LI/C 4/ & -7.97 & 9.14 & 5.87 & 23.57 & 31.19 \\
LI/A 5/ & 0.20 & 13.53 & 9.78 & 24.62 & 32.12 \\
\hline SOurce Own
\end{tabular}

Source: Own calculations.

1/ Calculations approximated with total costs rather than marginal costs; 2/ TOPLINA not included; 3/ Weighted by fees and costs; 4/ Weighted by the number of participants; $5 /$ Weighted by assets. 